\title{
A TAXA DE COLETA DE RESÍDUOS SÓLIDOS DOMICILIARES UMA ANÁLISE CRÍTICA
}

\author{
Dissertação apresentada à Escola de \\ Engenharia de São Carlos da \\ Universidade de São Paulo, como parte \\ dos requisitos para a obtenção do Título \\ de Mestre em Engenharia Civil: \\ Planejamento e Operação de Sistemas \\ de Transportes.
}


Aos meus pais José Tácito e Delfina, pela vida que me proporcionaram e pela base sólida que me permitiu chegar até aqui. 


\section{AGRADECIMENTOS}

A Deus, que me concedeu a graça de ter os pais que tive e à família que Ele permitiume constituir.

À Elzalina, Marcela e Bruna, que são a razão de minha vida, pelo amor e compreensão durante esta jornada.

Ao Prof. Dr. Edson Martins de Aguiar pelo apoio, pela disponibilidade e pela confiança depositada, desde o início.

Aos técnicos Thiago e Pablo pelo árduo trabalho desenvolvido na obtenção das informações, tão imprescindíveis e necessárias à realização deste trabalho.

Aos Prefeitos Municipais de Taiaçu, Luiz Anselmo, Caldeira e Sueli, que permitiram o início, o desenvolvimento e a conclusão deste valioso trabalho.

Ao amigo (irmão) e colega de profissão Prof. Dr. Jorge Munaiar Neto pelo incentivo, estímulo e disponibilidade.

À todas as pessoas que de forma direta ou indireta contribuíram para o enriquecimento deste trabalho.

Utilizando um trecho de uma estória certa vez ouvida, posso afirmar que "se enxergo distante é porque estou apoiado nos ombros de um gigante".

Este apoio foi conseguido graças à contribuição de cada um dos que aqui foi citado. 


\section{SUMÁRIO}

DEDICATÓRIA

AGRADECIMENTOS

ii

SUMÁRIO

iii

LISTA DE FIGURAS

vi

LISTA DE TABELAS

viii

LISTA DE ABREVIATURAS

ix

RESUMO

ABSTRACT

1. INTRODUÇÃO

1.1. Objetivos

1.1.1. Objetivo geral

1.1.2. Objetivos específicos

1.2. Justificativa

1.3. Limites da pesquisa

2. A PROBLEMÁTICA LIXO URBANO

2.1. O Despertar do homem para a questão ambiental

2.2. Questões conceituais e técnicas relacionadas ao lixo

2.2.1. O lixo

2.2.2. Geração do lixo

2.2.3. Remoção do lixo 16

2.2.4. Coleta seletiva 16

2.2.5. Reciclagem do lixo 18

2.2.6. Acondicionamento, coleta e destinação final 19

2.2.7. O gerenciamento integrado 
2.2.8. O Consórcio intermunicipal

2.3. A importância de solucionar os problemas do lixo 28

2.4. Legislação ambiental

3. A REMUNERAÇÃO PELOS SERVIÇOS PRESTADOS

3.1. A situação atual $\quad 34$

3.2. Modelo de cobrança através de taxa 35

3.2.1. Conceito de taxa $\quad 35$

3.2.2. Fato gerador da taxa 37

3.2.3. Poder de polícia

3.2.4. Serviço público 38

3.2.5. Base de cálculo $\quad 39$

3.3. Modelo de cobrança através de tarifa 39

$\begin{array}{ll}\text { 3.3.1. Tarifa } & 40\end{array}$

3.3.2. Valor da tarifa $\quad 41$

3.3.3. Legislação municipal para a cobrança de tarifa $\quad 42$

3.4. Constitucionalidade da cobrança de taxa de limpeza pública 43

3.5. O Gerenciador dos resíduos sólidos urbanos e suas dificuldades no 43 gerenciamento

3.6. Sustentabilidade financeira e ônus político 44

3.7. Formas de cobrança - exemplos e comentários 46

3.7.1. Situação existente 46

3.7.2. Cobrança da taxa de coleta em Campinas-SP. 47

3.7.2.1. Comentários $\quad 48$

3.7.3. Cobrança da taxa de coleta em Florianópolis-SC. 49

3.7.3.1. Comentários $\quad 50$

3.7.4. Cobrança da taxa de coleta em Vista Alegro do Alto-SP. 50 
3.7.5. O modelo adotado pela cidade de São Paulo - SP. 52

3.7.5.1. A forma de cobrança proposta 52

3.7.5.2. O aspecto legal 53

3.8. Um panorama da cobrança em alguns países $\quad 54$

3.8.1. A cobrança da taxa de coleta nos Estados Unidos 56

3.8.2. A cobrança da taxa de coleta na Itália $\quad 57$

4. INSTRUMENTO DE COLETA DE DADOS 58

4.1. Metodologia 58

5. RESULTADOS E DISCUSSÃO 61

5.1. Resultados obtidos $\quad 61$

5.1.1. Relação entre consumo de água e RSD gerado 61

5.1.2. Relação entre consumo de energia elétrica e RSD gerado 66

5.1.3. Relação entre área construída e RSD gerado 71

5.1.4. Outras informações obtidas 76

$\begin{array}{ll}\text { 5.2. Discussão } & 77\end{array}$

6. CONCLUSÕES E RECOMENDAÇÕES 78

$\begin{array}{ll}\text { 6.1. Considerações preliminares } & 78\end{array}$

6.2. Conclusões $\quad 80$

6.3. Recomendações para trabalhos futuros 80

7. REFERÊNCIAS BIBLIOGRÁFICAS

$\begin{array}{lr}\text { APENNDICE } & 89\end{array}$ 


\section{LISTA DE FIGURAS}

Figura 1 - Classificação dos resíduos sólidos a partir da fonte de geração

Figura 2 - Representação esquemática do Sistema de Manejo Integrado de Resíduos

Figura 3 - O processo da coleta de resíduos sólidos e suas inter-relações

Figura 4 - Sistema de gerenciamento de resíduos sólidos domiciliares, proposto por SCHALCH et LEITE (1998)

Figura 5 - Gráfico dos valores referentes ao consumo de água x quantidade de RSD Gerado

Figura 6 - Gráfico dos valores referentes ao consumo de água x quantidade de RSD gerado para faixa de consumo de 0 a $10 \mathrm{~m}^{3} / \mathrm{mês}$

Figura 7 - Gráfico dos valores referentes ao consumo de água x quantidade de RSD gerado para faixa de consumo de 10 a 20 m³ $/$ mes

Figura 8 - Gráfico dos valores referentes ao consumo de água x quantidade de RSD gerado para faixa de consumo de 20 a $30 \mathrm{~m}^{3} / \mathrm{mês}$

Figura 9 - Gráfico dos valores referentes ao consumo de água x quantidade de RSD gerado para faixa de consumo de 30 a 40 m³ $/ \mathrm{mês}$

Figura 10 - Gráfico dos valores referentes ao consumo de água x quantidade de RSD gerado para faixa de consumo de 40 a 50 m³

Figura 11 - Gráfico dos valores referentes ao consumo de água x quantidade de RSD gerado para faixas de consumo agrupadas (conf. Tab. 11)

Figura 12 - Gráfico dos valores referentes ao consumo de energia x quantidade de RSD gerado

Figura 13 - Gráfico dos valores referentes ao consumo de energia elétrica $\mathrm{x}$ quantidade de RSD gerado para faixa de consumo de 0 a $50 \mathrm{kwh} / \mathrm{mês}$

Figura 14 - Gráfico dos valores referentes ao consumo de energia elétrica $\mathrm{x}$ quantidade de RSD gerado para faixa de consumo de 50 a 100 kwh/mês

Figura 15 - Gráfico dos valores referentes ao consumo de energia elétrica $\mathrm{x}$ quantidade de RSD gerado para faixa de consumo de 100 a 150 kwh/mês 
Figura 16 - Gráfico dos valores referentes ao consumo de energia elétrica $\mathrm{x}$ quantidade de RSD gerado para faixa de consumo de 150 a 200 kwh/mês

Figura 17 - Gráfico dos valores referentes ao consumo de energia elétrica $\mathrm{x}$ quantidade de RSD gerado para faixa de consumo de 200 a 250 $\mathrm{kwh} / \mathrm{mês}$

Figura 18 - Gráfico dos valores referentes ao consumo de energia elétrica x quantidade de RSD gerado para faixa de consumo de 250 a 300 $\mathrm{kwh} / \mathrm{mês}$

Figura 19 - Gráfico dos valores referentes ao consumo de energia elétrica $\mathrm{x}$ quantidade de RSD gerado para faixa de consumo acima de 300 kwh/mês

Figura 20 - Gráfico dos valores referentes ao consumo de energia elétrica $\mathrm{x}$ quantidade de RSD gerado para faixas de consumo agrupadas (conf. Tab. 12)

Figura 21 - Gráfico dos valores referentes à área construída x quantidade de RSD gerado

Figura 22 - Gráfico dos valores referentes à área construída x quantidade de RSD gerado para faixa de construção até $50 \mathrm{~m}^{2}$

Figura 23 - Gráfico dos valores referentes à área construída x quantidade de RSD gerado para faixa de construção de 50 até $100 \mathrm{~m}^{2}$

Figura 24 - Gráfico dos valores referentes à área construída x quantidade de RSD gerado para faixa de construção de 100 até $150 \mathrm{~m}^{2}$

Figura 25 - Gráfico dos valores referentes á área construída x quantidade de RSD gerado para faixa de construção de 150 até $200 \mathrm{~m}^{2}$

Figura 26 - Gráfico dos valores referentes à área construída x quantidade de RSD gerado para faixa de construção de 200 até $250 \mathrm{~m}^{2}$

Figura 27 - Gráfico dos valores referentes à área construída x quantidade de RSD gerado para faixas de consumo agrupadas (conf. Tab. 13)

Figura 28 - Número de moradores por residência pesquisada, Taiaçu, 2005 


\section{LISTA DE TABELAS}

Tabela 1 - Critérios para cobrança da coleta de lixo - Campinas -SP 48

Tabela 2 - Exemplo hipotético 1 de cálculo da Taxa de Coleta 48

Tabela 3 - Exemplo hipotético 2 de cálculo da Taxa de Coleta 49

Tabela 4 - Tabela de freqüência de coleta - Florianópolis - SC 50

Tabela 5 - Exemplo hipotético 1 de cálculo da Taxa de Coleta 50

Tabela 6 - Tabela VI do Código Tributário de Vista Alegre do Alto - SP 51

Tabela 7 - Valores cobrados em função da quantidade de lixo gerado (1) 52

Tabela 8 - Valores cobrados em função da quantidade de lixo gerado (2) 53

Tabela 9 - Existência de base legal para a cobrança de taxas de coleta de lixo por parte das autoridades locais (SPET, 1999) 55

Tabela 10 - Modelo de planilha de coleta de dados 59

Tabela 11 - Valores obtidos por faixa de consumo de água 65

Tabela 12 - Valores obtidos por faixa de consumo de energia elétrica 70

Tabela 13 - Valores obtidos por faixa de consumo de energia elétrica 75 


\section{LISTA DE ABREVIATURAS}

ABES

ABIVIDRO

Vidro

ABNT

ANFPC

CEMPRE

$\mathrm{CF}$

IBGE

IETEC

IPT

IPTU

MESMIS

NBR

ONU

PIB

PNSB
Associação Brasileira de Engenharia Sanitária e Ambiental

Associação Técnica Brasileira das Industrias Automáticas de

Associação Brasileira de Normas Técnicas

Associação Nacional de Fabricantes de Papel e Celulose

Compromisso Empresarial para Reciclagem

Constituição Federal

Instituto Brasileiro de Geografia e Estatística

Instituto de Educação Tecnológica

Instituto de Pesquisas Tecnológicas

Imposto Predial e Territorial Urbano

Método de Avaliação de Sistema de Produção Incorporando

Indicadores de Sustentabilidade

Norma Brasileira

Organização das Nações Unidas

Produto Interno Bruto

Pesquisa Nacional de Saneamento Básico 


\section{RESUMO}

LEITE, M. F. (2006). A taxa de coleta de resíduos sólidos domiciliares - Uma análise crítica. Dissertação (Mestrado) - Escola de Engenharia de São Carlos, Universidade de São Paulo, São Carlos, 2006.

Os serviços de coleta e destinação final dos Resíduos Sólidos Urbanos -RSU, são de responsabilidade dos municípios. As despesas decorrentes dos serviços são repassadas na forma de taxas, geralmente lançadas junto com o IPTU. O objetivo desta cobrança é o de recuperar os recursos despendidos neste serviço. O trabalho proposto busca apresentar algumas formas de definição da "cota" que cada município adota para definir o valor a ser cobrado de cada domicílio no Brasil e alguns casos do exterior, bem como fazer uma análise sobre as possíveis falhas de alguns processos mais utilizados. Outro objetivo é o de realizar levantamento de dados junto a domicílios, no município de Taiaçu-SP., de informações (peso de lixo por residência, consumo de energia elétrica, consumo de água), que possam mostrar possíveis relações entre o volume de lixo gerado e os consumos ligados à residência (água, energia elétrica, etc.). Diante dos resultados obtidos, foi proposto um método que permitiu distribuir de forma proporcional a cada residência, o valor da taxa de coleta e destinação final dos resíduos sólidos domiciliares gerados.

Palavras-chave: 1. resíduos sólidos urbanos. 2. gerenciamento integrado de resíduos sólidos urbanos. 3. taxa de resíduos. 


\section{ABSTRACT}

LEITE, M. F. (2006). The domiciliary solid waste collection tax - A critical analysis. Dissertação (Mestrado) - Escola de Engenharia de São Carlos, Universidade de São Paulo, São Carlos, 2006.

The Urban Solid Waste - USW collection and final destination services, are the municipal responsibility. The expenses originated from the services are passed again in form of taxes, generally launched with the IPTU. The aim of this exaction is to restore the resource spent in this service. The proposed paper seeks to show some ways of the "quota" definition that every municipal district adopts to define the value to be charged of each home in Brazil and some cases abroad, as well as to do an analysis about possible faults of some most used process. Another objective is to come true the data survey with the residences in the municipal district of Taiaçu - SP, of information (trash weight per residence, the electrical energy consumption, water consumption), that can show possible relation between the generated trash volume and the consumptions linked to the residence (water, electric energy, etc.). Before the acquired results, was proposed a method that allows a proportional way to distribute in each home, a collection tax value and final destination of generated solid waste.

Keywords: 1.Urban solid waste. 2.Integrated management of the urban solid waste. 3. Waste tax. 


\section{1- INTRODUCÃ̃}

O mundo moderno oferece ao homem inúmeras facilidades, comodidades, praticidades, que tornam a vida mais ágil. Ganha-se tempo com as inovações e melhor qualidade de vida, porém numa análise mais objetiva, nota-se que outros aspectos de sua vida estão sendo prejudicados, pois como resultado destas melhorias, há a cobrança de um preço elevado, o "custo do lixo".

O Censo Demográfico 2000 do IBGE mostra que no Brasil houve, entre 1.992 e 1999, um aumento na quantidade de lixo coletado, tanto na zona urbana como na rural, sendo o percentual de coleta urbana da ordem de $93 \%$, e na zona rural em torno de $19 \%$.

Os dados apresentados mostram uma situação de grande relevância, na medida em que o lixo não coletado ou disposto de forma inadequada, acaba por propiciar a proliferação de vetores de doenças, bem como contaminar o solo ou corpos d'água, trazendo sérias consequiências para a saúde de nossa população, bem como a necessidade de se investir os escassos recursos no tratamento desta população.

Considerando as possibilidades de definição do termo genérico "lixo", ressalta-se que no presente trabalho, considerando-se as fontes de pesquisa bibliográfica e os autores citados, utilizaremos também a expressão "Resíduos Sólidos Domiciliares - RSD” ou ainda "Resíduos Sólidos Urbanos -RSU”. É importante ainda destacar que o foco deste trabalho está voltado para aquele resíduo gerado a partir das residências, ou seja, os domiciliares.

Segundo a Pesquisa Nacional de Saneamento Básico - PSNB - 2000 (IBGE-2002), coleta-se no Brasil diariamente cerca de 162.232 toneladas de Resíduos Sólidos Urbanos - RSU, e em quase todos os municípios brasileiros, os serviços de limpeza urbana, total ou parcialmente, são remunerados através de uma "taxa", geralmente 
cobrada na mesma guia do Imposto Predial e Territorial Urbano - IPTU, e tendo a mesma base de cálculo deste imposto, ou seja, a área do imóvel (área construída ou área do terreno).

Como não pode haver mais de um tributo com a mesma base de cálculo, essa taxa já foi considerada inconstitucional pelo Supremo Tribunal Federal, e assim sua cobrança vem sendo contestada em muitos municípios, que passam a não ter como arrecadar recursos para cobertura dos gastos dos serviços, que podem chegar, algumas vezes, a mais de $15 \%$ do orçamento municipal.

Diante deste quadro, executar os serviços de coleta, transporte, destinação final e varrição de logradouros públicos, passa a representar um dos maiores investimentos realizados pelos municípios brasileiros, que enfrentam na sua grande maioria a convivência com baixas arrecadações, sendo que possuem um orçamento com pouca ou nenhuma flexibilidade financeira, pois de modo geral gastam cerca de $50 \%$ com a folha de pagamento; por força de Lei ainda são obrigados a aplicar $25 \%$ no ensino escolar, gastam cerca de $20 \%$ com as despesas da saúde, restando apenas, em muitos casos, valores próximos a 5\% para investir em outros setores do município.

Soma-se a esta situação, o fato de que as administrações municipais possuem um fluxo de caixa desequilibrado, suas tarifas estão desatualizadas, a arrecadação geralmente insuficiente e ainda são penalizados com a falta de capacitação técnica e profissional de seu quadro de colaboradores.

A pesquisa, de meios que auxiliem os administradores de municípios de médio e pequeno porte na definição de quanto cobrar pelos serviços prestados, será de fundamental importância na solução da arrecadação dos recursos necessários ao desenvolvimento das ações que promovam crescimento sustentável e viável economicamente. 


\section{1 - Objetivos}

\subsubsection{Objetivo geral}

O presente trabalho tem por objetivo avaliar as formas de cobrança praticadas pelas administrações municipais, particularmente em municípios de médio e pequeno porte, para a realização dos serviços de coleta e destinação final de resíduos sólidos domiciliares urbanos.

\subsubsection{Objetivos específicos}

$\checkmark$ Pesquisar as legislações municipais, para conhecer as formas de cobrança pela coleta de lixo;

$\checkmark$ Coletar informações, junto a uma amostra de domicílios, no município de Taiaçu-SP., para obter dados sobre a quantidade de lixo gerado em cada residência, bem como o consumo de energia elétrica;

$\checkmark$ Obter junto aos cadastros da Prefeitura Municipal de Taiaçu-SP., informações complementares sobre o imóvel (consumo de água e área construída da residência);

$\checkmark$ Com o auxílio do programa Microsoft Excel, lançar pontos relativos aos pares de valores consumo de água-lixo gerado, consumo de energia-lixo gerado, e ainda área construída-lixo gerado. Verificar então, a possibilidade de se propor uma equação que melhor apresente a quantidade de lixo gerado na residência, tendo-se por referência, alguns dos consumos estudados;

$\checkmark$ Baseado nos resultados, propor um método que permita às administrações municipais um modo mais adequado de definir o valor a ser cobrado dos contribuintes, pelos serviços de coleta e remoção do lixo domiciliar. 


\section{2 - Justificativa}

Segundo o IBGE (2000), no Brasil a cobrança pelos serviços de coleta e destinação final dos resíduos sólidos domiciliares é feita em 2.484 municípios, onde estão cerca de $66 \%$ da população brasileira, de acordo com a pesquisa.

Tal cobrança tem como objetivo cobrir os custos decorrentes dos serviços de coleta, transporte e destinação final, atividades estas que envolvem diretamente as áreas de gestão do processo, utilizando veículos e máquinas em todas as etapas, servindo-se ainda de métodos de roteirização, para a definição do roteiro de coleta, e ainda, dentre outras atividades, realizando a manutenção da frota envolvida com os serviços de coleta e transporte dos resíduos urbanos coletados.

Dentre estes municípios que cobram a taxa de coleta, $93 \%$ dos mesmos a fazem em conjunto com o lançamento do Imposto Predial e Territorial Urbano - IPTU.

Considerando-se os municípios com população até 50.000 habitantes, que segundo a pesquisa, representam $86 \%$ do total, verifica-se a grande necessidade de estudos e pesquisas onde seja feito amplo levantamento de dados, na forma de legislação tributária, e de dados específicos de cada gestor dos serviços de limpeza pública, para conhecer melhor esta realidade e verificar a possibilidade de adequação dos critérios de cobrança.

Em levantamento preliminar realizado, verificou-se uma grande incidência de aspectos ilegais na forma de atribuição do valor a ser cobrado, por residência, pelos serviços de coleta de resíduos sólidos domiciliares.

As prefeituras utilizam como parâmetro de cálculo, a área construída do imóvel, lançando o respectivo valor juntamente com o IPTU anual.

Este procedimento, embora de fácil aplicação por parte da administração municipal, na medida em que dispõe em seu cadastro imobiliário da quantidade de área construída do 
imóvel, acaba confrontando com a Constituição Federal, que em seu artigo 145, § $2^{\circ}$, estabelece a impossibilidade de criação de taxas que tenham a mesma base de cálculo de impostos.

Com o objetivo de aprofundar o conhecimento nesta questão, que atinge muitos municípios de médio e pequeno porte, afetando diretamente sua população, com a cobrança de uma taxa baseada em parâmetros que não refletem a realidade dos fatos, o trabalho proposto é bastante justificável, na medida em que poderá servir de base para uma adequação nas formas de cobrança da taxa de coleta, e ainda propiciar justiça social quanto à definição da cota de cada contribuinte de forma mais apropriada.

\section{3 - Limites da pesquisa}

O trabalho procura fazer uma avaliação da forma de cobrança da taxa de coleta de resíduos sólidos domiciliares, buscando reunir informações junto a uma amostra da população urbana do município de Taiaçu-SP., bem como pesquisar em outros municípios, de que forma se dá esta cobrança.

O município de Taiaçu, localizado na região norte do estado de São Paulo, situado na bacia hidrográfica do Rio Turvo, a uma altitude de 565 m, foi fundado em 1.953 e conta com uma população da ordem de 6.000 habitantes (estimativa IBGE 2005), distribuídos em uma área territorial de $107,2 \mathrm{~km}^{2}$. Tem sua economia voltada para a agricultura (laranja, cana, goiaba, manga, etc.).

Ao obter as informações desta população, todo o método de estudo desenvolvido estará vinculado a esta população amostral, sendo que os resultados alcançados poderão ser utilizados como ferramenta para adequação da legislação do município.

Há, a princípio, a possibilidade de utilização destes resultados para que municípios de mesmo porte possam iniciar o trabalho em busca de melhores soluções para a questão da definição da taxa de coleta a ser cobrada dos contribuintes. 
Neste trabalho limitou-se a estudar a problemática relacionada à cobrança da taxa de coleta e destinação final do lixo domiciliar, sendo que o gerenciamento dos demais tipos de resíduos não foi analisado.

As informações, necessárias à elaboração do estudo proposto, conduziram à implantação de uma pesquisa onde a quantidade de resíduos sólidos gerados nos domicílios da amostra foi pesada individualmente, uma vez que a obtenção destes dados é relevante e consistente para a elaboração do trabalho.

As informações obtidas foram complementadas com dados existentes nos cadastros municipais da Prefeitura de Taiaçu, que após a coleta possibilitaram a verificação da hipótese analisada. 


\section{A PROBLEMÁTICA LIXO URBANO}

\subsection{O Despertar do homem para a questão ambiental}

Adestram-se os animais, se cultivam as árvores e se educam os seres humanos... Apanhando esta afirmação, poderia ser dito que o cultivo, o adestramento, a educação passam pela vida. Nada disso é possível sem vida.

Homens e mulheres inventam a história que eles mesmos criam e fazem. E é exatamente a história e a cultura que homens e mulheres criam e fazem, a cultura alongando-se sobre a história, a história voltando-se sobre a cultura, que gera a necessidade de educar. A educação nasce na relação entre a cultura e a história, dentro da cultura e da história. Por isso não se faz educação na cabeça de ninguém; se faz educação no contexto histórico, no contexto cultural (VIEZZER e OVALLES, 1995).

A questão ambiental surgiu de maneira explosiva há duas ou três décadas. Até então, apenas os aspectos sanitários do problema eram abordados, principalmente com relação à poluição da água e os conseqüentes episódios de mortandade de peixes, à poluição do ar e as perturbações e doenças dela advindas. O próprio termo preservacionismo aplicava-se tão somente à proteção contra a erosão, reconhecida desde os tempos da colonização da América do Norte como causa da perda de fertilidade dos solos (BRANCO, 1999, p. 5).

Historicamente pode-se dizer que o despertar de uma 'consciência ecológica' iniciou-se na década de 60 , pois esta foi uma década marcada pelo conflito de interesses entre preservacionistas e desenvolvimentistas. $\mathrm{O}$ conflito da questão ambiental prolongou-se enquanto políticas desenvolvimentistas eram definidas no sentido de incrementar a atividade humana, e a preservacionista aquela que buscava restringir tal atividade (LERÍPIO, 1999, p. 8). 
Para que se possa contribuir com a conservação do meio ambiente, deve ser estabelecida uma relação de harmonia e não de domínio da natureza. Nesse sentido dois princípios básicos de sustentabilidade são de fundamental importância no desenvolvimento de uma sociedade: o primeiro diz que não se devem retirar recursos de natureza além de sua capacidade de reposição. Já o segundo diz que não devem ser adicionados na natureza, resíduos em quantidades acima de sua capacidade de absorção.

A partir das últimas décadas a questão ambiental tornou-se uma preocupação mundial. A grande maioria das nações do mundo reconhece a emergência dos problemas ambientais. A destruição da camada de ozônio, acidentes nucleares, alterações climáticas, desertificação, armazenamento e transporte de resíduos perigosos, poluição hídrica, poluição atmosférica, pressão populacional sobre os recursos naturais, perda de biodiversidade, são algumas das questões a serem resolvidas por cada uma das nações do mundo, segundo suas especificidades (MUNHOZ, 2002)

Segundo Leripio (1999), a reunião do Clube de Roma em 1970 buscava alertar as autoridades para a diferenciação entre crescimento e desenvolvimento econômico. No ano seguinte resultou dessa reunião o documento "Limites do Crescimento", o qual colaborou para que em junho de 1972 se realizasse a Primeira Conferência das Nações Unidas, em Estocolmo.

Na década de 80 os cientistas chamaram a atenção para os problemas urgentes e complexos ligados à própria sobrevivência do homem: um planeta em processo de aquecimento, ameaças à camada de ozônio, desertos que tornam a terra imprópria para o cultivo (BRUNDTLAND, 1991).

Em 1987 a Comissão Mundial de Meio Ambiente e Desenvolvimento das Nações Unidas apresentou ao mundo um relatório, denominado de Relatório Brundtland, sobre o tema desenvolvimento. Esse relatório apresentou o conceito de desenvolvimento sustentável, além de afirmar que um desenvolvimento sem melhoria da qualidade de vida das sociedades não poderia ser considerado como desenvolvimento. 
transformavam em desertos inúteis, sendo que em 30 anos corresponderia a uma área igual às áreas somadas da Alemanha Federal, Espanha, Inglaterra, Itália, França e Noruega, ou seja, $2.170 .000 \mathrm{~km} 2$; eram então destruídos mais de onze milhões de hectares de florestas que representaria em 30 anos uma área igual à da Índia $3.500 .000 \mathrm{~km} 2$. O preço desse progresso seria por em risco a própria sobrevivência, pois sem o uso sabiamente dirigido dos recursos naturais, não haveria desenvolvimento sustentável (BRUNDTLAND, 1991, p. 2).

Uma das grandes contribuições para o agravamento dos problemas ambientais foram as mudanças ocorridas na tecnologia desenvolvida para o setor agropecuário. Estas mudanças dizem respeito à substituição da tração animal por motomecanização e dos insumos oriundos da propriedade por insumos industrializados.

As conseqüências das mudanças atingiram tanto o meio urbano, onde se instalaram as indústrias de fertilizantes e agrotóxicos, como no campo, onde aumentou -se drasticamente a fronteira agrícola sem levar em consideração a utilização racional dos recursos naturais.

Entendeu-se então como imprescindível, que houvesse, simultaneamente, uma ação positiva por parte dos governos e dos povos, no sentido de poupar os recursos da natureza, aproveitando-os sem esgotá-los e sem transformar o meio ambiente de pródigo em hostil, poluído, inadequado à sobrevivência humana.

Na década de 90, o grande acontecimento em termos ambientais foi a Conferência do Rio de Janeiro, conhecida mundialmente como "ECO-92" e "Rio 92" na qual se fizeram representar mais de 100 chefes de Estados, culminando com a elaboração do documento que passou a ser chamado de Agenda 21 (BEZERRA e FERNANDES, 2000).

Para Malhadas (2001, p. 13) a Agenda 21 é um documento que resultou de um consenso internacional e um compromisso assumido pelos chefes de estado de 178 nações perante a ONU, apresentando as diretrizes básicas para o desenvolvimento sustentável. Organizado por grupos temáticos em 40 capítulos, no seu contexto estão inseridos os posicionamentos anteriores das Nações Unidas e das resoluções aprovadas pela sua Assembléia Geral, e, em especial, as resultantes da Conferência sobre Meio Ambiente e Desenvolvimento, de 22.12.1989, onde são apontados os meios de implementação de 
planos, programas e projetos, direcionados à melhoria da qualidade de vida, e às grandes questões relativas a conservação e gestão de recursos para o desenvolvimento sustentável.

\title{
2.2 Questões conceituais e técnicas relacionadas ao lixo
}

\subsubsection{O Lixo}

\begin{abstract}
Não é uma tarefa fácil definir lixo urbano, pois sua origem e formação estão ligadas a inúmeros fatores, tais como: variações sazonais, condições climáticas, hábitos e costumes, variações na economia etc. Assim, a identificação desses fatores é uma tarefa muito complexa e somente um intenso estudo, ao longo de muitos anos, poderia revelar informações mais precisas no que se refere à origem e formação do lixo no meio urbano. Entretanto, é comum definir como lixo todo e qualquer resíduo que resulte das atividades diárias do homem na sociedade. Estes resíduos compõem-se basicamente de sobras de alimentos, papéis, papelões, plásticos, trapos, couros, madeira, latas, vidros, lama, gases, vapores, poeiras, sabões, detergentes e outras substâncias descartadas pelo homem no meio ambiente (LIMA, 1991, p. 11).
\end{abstract}

A Norma NBR 10.004 - Resíduos Sólidos - Classificação classifica os resíduos sólidos quanto ao risco à saúde pública e ao meio ambiente, dividindo-os em dois grupos, dos perigosos e não perigosos, sendo este último grupo subdividido em não inerte e inerte.

Para melhor compreensão dos efeitos desta norma, define-se como:

- Resíduos Sólidos: resíduos nos estados sólido e semi-sólido, que resultam de atividades da comunidade de origem industrial, doméstica, hospitalar, comercial, agrícola, de serviços e de varrição. Ficam incluídos nesta definição os lodos provenientes de sistemas de tratamento de água, aqueles gerados em equipamentos e instalações de controle de poluição, bem como determinados líquidos cujas particularidades tornem inviável o seu lançamento na rede pública de esgotos ou corpos de água, ou exijam para isso soluções técnica e economicamente inviáveis, em face à melhor tecnologia disponível.

- Periculosidade de um resíduo: característica apresentada por um resíduo que, em função de suas propriedades físicas, químicas ou infectocontagiosas, pode apresentar riscos à saúde pública, provocando ou acentuando, de forma significativa, um aumento de mortalidade ou incidência de doenças. Envolve 
ainda aqueles que oferecem riscos ao meio ambiente, quando o resíduo for gerenciado de forma inadequada.

Resíduos Classe I - Perigosos são aqueles que apresentam periculosidade, conforme definido anteriormente, ou uma das características seguintes:

- Inflamabilidade

- Corrosividade

- Reatividade

- Toxicidade

- Patogenicidade

\section{Resíduos Classe II - Não-perigosos}

Resíduos Classe II A - Não inertes são aqueles que não se enquadram nas classificações de resíduos Classe I - Perigosos ou de resíduos classe II B - Inertes, nos termos da norma NBR 10.004. Os resíduos Classe II A - Não inertes podem ter propriedades, tais como: combustibilidade, biodegradabilidade ou solubilidade em água.

Resíduos Classe II B - Inertes são quaisquer resíduos que, quando amostrados de forma representativa, segundo a NBR 10.007, e submetidos a um contato dinâmico e estático com água destilada ou desionizada, à temperatura ambiente, conforme teste de solubilização (NBR 10.006), não tiverem nenhum de seus constituintes solubilizados a concentrações superiores aos padrões de potabilidade de água, excetuando-se os padrões de aspecto, cor, turbidez, dureza e sabor. Como exemplos destes materiais, podem-se citar rochas, tijolos, vidros e certos plásticos e borrachas que não são decompostos prontamente.

De acordo com o "Sistema de Resíduos Sólidos" que tenha sido concebido, alguns autores fazem diversos tipos de classificação dos mesmos, com distintos critérios. SCHALCH (1995), ao classificar os resíduos pela sua fonte de geração, apresenta o seguinte diagrama esquemático. 


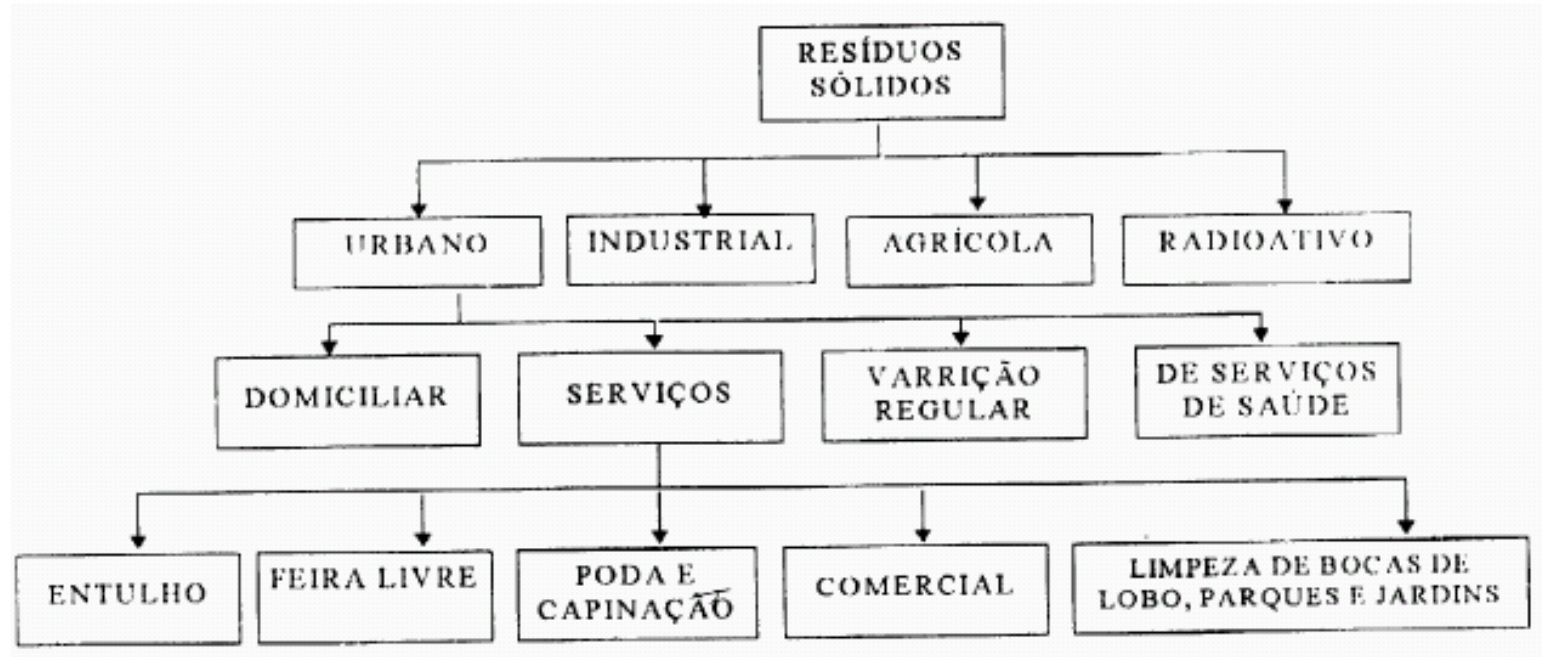

Figura 1 - Classificação dos resíduos sólidos a partir da fonte de geração

SCHALCH (1995)

Ainda segundo SCHALCH et al. (1998), os resíduos sólidos urbanos gerados em uma cidade, que são de atribuição e responsabilidade das prefeituras desde a coleta até a destinação final, são dos tipos domiciliar, comercial (co-responsável por quantidades pequenas) e de serviços. A ênfase aqui será dada aos resíduos sólidos domiciliares, constituídos basicamente por restos alimentares, embalagens, tais como vasilhames plásticos, de vidro ou latas, papéis, papelão, plásticos, vidros, varredura, folhagens, e outros (SCHALCH et al. 1998).

Para Fonseca (1999) os materiais residuais têm várias origens como: agrícolas, pecuaristas, de silviculturas, pesqueiras, mineradoras, industriais, comerciais, culturais, entre outras, caracterizando-se então, por uma grande diversidade tipológica. Em primeiro lugar categorizam-se os materiais sólidos e materiais líquidos, e nestes se incluem os esgotos domésticos e os industriais.

Os resíduos de maneira geral são rotulados como lixo, que pressupõe descartável, imprestável, ou seja, material desprovido de utilidade. O primeiro problema de administração de materiais imprestáveis consiste na eliminação dos mesmos. Isto sugere muitas práticas operacionais, desde o acondicionamento à disposição final.

Para Calderoni (1998, p. 49) "o conceito de lixo e de resíduo pode variar conforme a época e o lugar. Depende de fatores jurídicos, econômicos, ambientais, sociais e tecnológicos". A definição de lixo, resíduo e reciclagem, variam conforme a situação 
em que sejam aplicadas. Seu uso na linguagem se distingue de outras acepções adotadas consoante a visão institucional ou de acordo com seu significado econômico.

O conceito de imprestável ou descartável atribuído ao lixo tem sido muito questionável, à medida que ações concretas de reciclagem e reutilização de alguns materiais têm sido desenvolvidas e implementadas. Em muitos casos, ocorre esforço de aproveitamento, pelo menos parcial, de alguns tipos de resíduos sólidos ou líquidos, fato que dá aos mesmos um valor econômico, um sentido de utilidade. O reaproveitamento de resíduos procura reintegrá-los no circuito de economia, dando-lhes valor de mercado, de matérias primas ou de bens ultimados.

Uma das mais graves causas da poluição urbana é sem dúvida o lixo que o próprio homem produz. No sentido etimológico, a palavra lixo quer dizer o que não presta, e sempre se joga fora, ou seja, imundice, sujeira, inutilidades, coisas indesejáveis. Estas palavras sempre foram consideradas sinônimas de lixo o que, em parte, denuncia a relação das pessoas com "os restos" oriundos da sua atitude de viver. O lixo é então a expressão de uma sociedade. Sua composição e o tratamento recebido por parte da cidade indicam o tipo de sistema sob o qual a população está submetida, reproduzindo a relação desta com a natureza (LIMA, SOUSA e TÁVORA, 2001).

Em todo o mundo os problemas do lixo, principalmente o seu destino, vêm sendo sistematicamente considerados, tendo em vista que a crescente produção de resíduos nos centros urbanos vem causando a devastação do ambiente natural.

A problemática do lixo historicamente vem se agravando na medida em que a sociedade com o objetivo de atender suas necessidades, aumenta o consumo. O lixo se resume então a um dos subprodutos do conjunto de atividades desenvolvidas pela sociedade.

Até recentemente este problema, com base em vários exemplos, deixava transparecer que passava despercebido pela humanidade, uma vez que o volumoso lixo que produzia era em muitas situações e continua sendo, lançado sem grandes preocupações em mares, rios ou em qualquer 'área vazia' sem a consciência das implicações para o meio ambiente (TAVARES e BARROS JR, 2000, p. 204).

Segundo Calderoni (1998, p. 50): 
A legislação brasileira estabelece que o lixo doméstico é propriedade da Prefeitura, cumprindo-lhe a missão de assegurar sua coleta e disposição final. $\mathrm{O}$ transporte e a disposição final do lixo industrial constituem, por outro lado, encargo da indústria, sujeitos aos regulamentos e à fiscalização do poder publico.

É preciso ter em conta que a industrialização aumenta a quantidade e piora a qualidade do lixo, acrescentando-lhe uma infinidade de produtos e matérias-primas que levam centenas ou milhares de anos para serem degradados.

Resíduos sólidos das atividades agrícolas e da pecuária, como embalagens de adubos defensivos agrícolas, ração, restos de colheita, etc, em varias regiões do mundo, estes já constituem uma preocupação crescente, destacando-se as enormes quantidades de esterco animal geradas nas fazendas de pecuária intensiva. Também as embalagens de agroquímicos diversos, em geral altamente tóxicos, têm sido alvo de legislação especifica, definindo os cuidados na sua destinação final e, por vezes, coresponsabilizando a própria indústria fabricante destes produtos (Universidade São Judas Tadeu, 1999).

Segundo Figueiredo (1995) nos períodos de chuva, ocorrem nos depósitos de lixo, infiltrações de água que penetram até as águas subterrâneas. Substâncias solúveis presentes no lixo, são assim arrastadas para dentro do solo. De modo análogo com o que ocorria com a infiltração proveniente do lixo, predominam substâncias inorgânicas, como cloretos, nitratos, sulfatos, carbonatos, e fosfatos, entre outros íons, magnésio, sódio, potássio, cálcio e amônio. Íons de metais pesados que poderão comprometer altamente à saúde. O valor de DBO5 (demanda bioquímica e oxigênio) de águas de infiltração provenientes de depósitos de lixo mais antigos é da ordem de 200 a $2.000 \mathrm{mg}$ de oxigênio por litro de água. Em lixo recente, estes valores podem ser de até 10 vezes mais. O lixo de procedência industrial altera a composição das águas de infiltração, sendo que estas passam a conter substâncias de forte ação tóxica, quando ocorre despejo ilegal, e sem medidas de segurança de resíduos como arseniatos e cianetos. A natureza do solo influencia também a velocidade do escoamento das águas infiltradas, de modo que depósitos de lixo podem comprometer as águas profundas imediatamente ou após 
alguns decênios. Assim, estas águas de infiltração provenientes de depósitos de lixo devem ser recolhidas e tratadas antes de serem reconduzidas ao ciclo normal.

\subsubsection{Geração do lixo}

Vários indicadores ou fatores podem auxiliar no gerenciamento dos resíduos urbanos. "Diferentemente de uma informação meramente numérica, um indicador descreve um processo específico ou um processo de controle". Esta é a definição dada ao termo por Astier e Masera (1996), ao estabelecerem o MESMIS - Método de Avaliação de Sistema de Produção Incorporando Indicadores de Sustentabilidade.

É sabido que alguns fatores influenciam na origem e formação do lixo no meio urbano. Tais fatores que são importantes, dentre outros, nas avaliações dos problemas pertinentes aos resíduos sólidos são, segundo Andrade (1989), os que se seguem:

· econômico;

- ambiental;

- sanitário;

- comunitário;

- cultural;

- político;

- número de habitantes do local e expansão da cidade;

- tipos usuais de acondicionamento;

- tipos de coletas e de equipamentos de coleta;

- sistema viário e tipos de pavimentos das vias;

- distância ao destino final e forma adequada de destino final;

- área relativa de produção, disciplina e controle dos pontos produtores;

- variações sazonais;

- condições climáticas;

· hábitos;

- níveis educacionais;

- segregação na origem;

• sistematização da origem;

- leis e regulamentações específicas. 


\subsubsection{Remoção do lixo}

Segundo Figueiredo (1995), o aspecto mais importante a ser considerado na remoção do lixo é o de evitar as conseqüências nocivas do mesmo: o volume deve ser reduzido, as condições higiênicas devem ser melhoradas e as substâncias solúveis presentes não podem penetrar no solo e nos lençóis de água.

A correta remoção dos resíduos sólidos, com equipamentos apropriados e pessoal treinado para essa finalidade, é que contribuirá para um nível maior e melhor de reciclagem e reutilização dos resíduos.

\subsubsection{Coleta seletiva}

A coleta seletiva é um serviço especializado em coletar o material devidamente separado e classificado pela fonte geradora. Além de facilitar a reciclagem, constitui-se em um processo de valorização dos resíduos, visando sua reintrodução no ciclo produtivo.

A coleta do lixo é a maior aliada na reciclagem, pois, após a separação dos materiais na própria fonte geradora eles são coletados e encaminhados para o beneficiamento. Este sistema facilita a reciclagem porque os materiais estarão mais limpos, e conseqüentemente, com maior potencial de reaproveitamento (CALDERONI, 1998).

Para Oliveira (1996, p. 62) “a falta de recursos materiais para a coleta, costumeiramente, é um fator que leva o poder público municipal a descuidar de uma melhor discussão, em termos das condições sanitárias dos municípios”.

A coleta seletiva além da conscientização é uma questão de educação ambiental. Uma das formas de levar a educação ambiental à comunidade é pela ação direta do professor na sala de aula, e em outras atividades, como leituras, trabalhos escolares, palestras, debates e pesquisas.

O poder público pode propiciar um zoneamento ambiental, como monitoramento, por amostragem, e, dispondo de estímulos, através de benefícios localizados, premiar a eficiência, melhorando o nível de conscientização da população urbana, nesse sentido. 
Demore o quanto for necessário, o processo educativo trará conseqüência, a educação sanitária, a preservação do meio ambiente, que são heranças inalienáveis, além da rentabilidade econômica de um processo de transformação industrial (OLIVEIRA, 1996, p. 62).

Os sistemas mais conhecidos e utilizados para a coleta seletiva de resíduos sólidos urbanos são:

- Coleta porta-a-porta: os resíduos selecionados são retirados diretamente dos domicílios pelo poder público, sucateiros ou empresa responsável pelo serviço;

- Entrega voluntária: a população se dirige a locais previamente definidos e devidamente preparados para receber os resíduos recicláveis, geralmente em recipientes apropriados.

A prática da coleta seletiva reveste-se de forte conteúdo comunitário qualquer que seja a abrangência do projeto (em um bairro, em um condomínio, em qualquer estabelecimento de serviços, ou comercial).

Segundo Calderoni (1998), a Coleta Seletiva enquanto processo de "separação prévia de materiais passíveis de reaproveitamento ganhou considerável desenvolvimento em grande número de países, tendo, aparentemente, sido iniciada nos Estados Unidos no início do século XX”. A sistemática adotada envolvia a separação domiciliar do lixo em três grupos de resíduos: materiais orgânicos; cinzas resultantes da combustão, geralmente da madeira e do carvão; materiais de valor comercial, como papel, cacos de vidro, metais e tecidos. Esses resíduos, assim separados, eram retirados por comerciantes ou industriais. É importante notar que não constituía atribuições das Prefeituras a coleta do lixo domiciliar. Mais tarde a mesma sistemática foi introduzida nos paises escandinavos e no norte da Alemanha, de onde provavelmente disseminou-se para outras partes da Europa. Na Austrália a coleta seletiva teve seu início em 1.990, como iniciativa governamental, e, na China a seleção do lixo nas residências ocorre desde 1950.

O crescimento acelerado e desordenado das cidades tem ocasionado um grande problema no que se refere ao lixo urbano. O espaço para deposição ao redor dos centros urbanos tem se reduzido significativamente, além disso, nos paises em desenvolvimento os recursos financeiros para manter a infra-estrutura de saneamento adequada são 
escassos. Diante deste fato, a partir do final da década de 80 , a coleta seletiva dos resíduos sólidos urbanos e o reaproveitamento dos materiais como insumos industriais tem sido proposto como solução eficiente e atrativa para o gerenciamento dos resíduos sólidos no Brasil (OBLADEN, TOKUDOME e WESTPHAL, 1995). Em função da crescente consciência da necessidade da reciclagem, um número cada vez maior de municípios vem desenvolvendo ações voltadas para a implantação de programas de coleta seletiva.

\subsubsection{Reciclagem do lixo}

Um programa de reciclagem bem conduzido tende a desenvolver na população uma nova mentalidade sobre questões que envolvem a economia e a preservação do meio ambiente. É relevante mencionar a confusão que se faz sobre as palavras reciclar e reutilizar.

Reutilizar um determinado produto significa reaproveitá-lo sem qualquer alteração física, modificando ou não o seu uso original. Reutilizam-se embalagens de vidro de alimentos quando for consumido o produto. Usam-se, por exemplo, os recipientes para acondicionar objetos diversos ou o mesmo produto, após a lavagem e esterilização da embalagem.

Já na reciclagem o produto inicial é submetido a um processo de transformação, podendo ser artesanal ou industrial. Exemplo disso são os pneus de automóveis, que são reciclados quando, após sua vida útil são transformados em recipientes para acondicionamento de lixo.

Em ambos os processos, são evidentes o reaproveitamento do produto inicial. Sendo assim, define-se que reciclar é não jogar fora, é inserir um determinado produto acabado, e já utilizado para o seu fim inicial, em um novo processo de produção.

A reciclagem cumpre seu papel quando o resíduo depois de submetido a um processo de seleção e tratamento transforma-se em novo produto capaz de ser comercializado no mercado. 
Para Motta e Sayago (1998, p. 6):

O nível de reciclagem é determinado pela participação da produção da matéria reciclável em proporção ao total de matéria virgem utilizada no processo industrial. Em termos de expansão, a reciclagem das sucatas de aço e vidro declinaram nos últimos anos, a de papel estabilizou-se e presenciou-se um crescimento significativo na de plásticos e, principalmente, na de alumínio.

Apesar da situação ainda estar longe da ideal, o Brasil é um bom exemplo em alguns setores de reciclagem. O país é líder na reciclagem de latinhas de alumínio, onde $85 \%$ dessas embalagens são recicladas. Nas embalagens de vidro das 890 mil toneladas produzidas em 2001, 360 mil (42\% do total) voltaram para a indústria, segundo a ABIVIDRO (Associação Técnica Brasileira das Industrias Automáticas de Vidro).

Com o papel, a quantidade é um pouco menor: 37,5\% de acordo com a Associação Nacional de Fabricantes de Papel e Celulose (ANFPC). Em números absolutos, isso significa 1,6 milhão de toneladas de papel e papelão reciclados (CEMPRE, 2001).

Conforme Fellemberg (1977), a obtenção de produtos úteis a partir do lixo, como obtenção de energia e formação de adubos, é procurada sempre que este procedimento se mostra economicamente viável. A crescente redução de fontes de matérias-primas conduzirá no futuro a procurar um reaproveitamento ainda maior dos principais componentes dos resíduos sólidos.

\subsubsection{Acondicionamento, coleta e destinação final}

É muito importante conhecer as características físicas e químicas do lixo, assim como suas tendências futuras, pois tais parâmetros possibilitam calcular a capacidade e tipo dos equipamentos de coleta e tratamento, e o destino final. Propriedades como o volume, por exemplo, determinam as dimensões dos locais de descarga ou estações de transbordo, além do tempo de vida de um aterro sanitário.

A composição serve para mostrar as potencialidades econômicas do lixo, subsidiando informações para escolha do melhor e mais adequado sistema de tratamento e disposição final. Pode-se dizer ainda que a eficiência dos sistemas de coleta e disposição final está 
fundamentada numa análise criteriosa das características físicas e químicas dos resíduos (LIMA, 1991, p. 15).

Segundo o IETEC (1999, p. 27-41), "o acondicionamento do lixo urbano constitui a fase de pré-coleta atribuída exclusivamente aos municípios, podendo ser conceituada como o ato de embalar em sacos plásticos ou em outras embalagens recomendadas, de acomodar em recipientes ou contenedores adequados e padronizados, os resíduos para fins de coleta e transporte".

A coleta dos resíduos sólidos urbanos é de competência do Poder Público Municipal, que poderá executá-la por diferentes sistemas:

- Coleta regular - executada por processo convencional ou alternativo, com periodicidade definida, atingindo o maior universo possível, domicílio por domicílio;

- Coleta extraordinária - executada esporadicamente, a critério do órgão público de limpeza urbana;

- Coleta especial - executada para atender os casos de resíduos especiais, como a de lixo hospitalar;

- Coleta seletiva - executada para remoção distinta dos resíduos recicláveis, que pode ser realizada de porta em porta ou de forma espontânea.

A coleta seletiva e a reciclagem de resíduos são uma solução indispensável, por permitir a redução do volume de lixo para disposição final em aterros e incineradores. São alternativas ecologicamente corretas, pois prolonga a vida útil dos aterros sanitários, o meio ambiente é menos contaminado, e o uso dos materiais recicláveis diminui a utilização dos recursos naturais.

Os maiores beneficiados por esse sistema são o meio ambiente e a saúde da população. A reciclagem de papéis, vidros, plásticos e metais - que representam em torno de $40 \%$ do lixo doméstico - reduz a utilização dos aterros sanitários, prolongando sua vida útil. Se o programa de reciclagem contar também com uma usina de compostagem, os benefícios são ainda maiores. Além disso, a reciclagem implica uma redução significativa dos níveis de poluição ambiental e do desperdício de recursos naturais, através da economia de energia e matérias-primas (IETEC 1999). 
Embora normalmente a coleta seletiva apresente um custo mais elevado do que os métodos convencionais, iniciativas comunitárias ou empresariais podem reduzir estes custos, e mesmo produzir benefícios para entidades ou empresas.

Quando se pensa na questão do lixo, o mais difícil de equacionar e que demanda maior pesquisa, é a destinação final. Afinal, de que adianta separar o lixo se não é conhecido o processo como um todo? Para onde vai o lixo coletado? As alternativas de destinação atuais são ambientalmente satisfatórias? Como melhorar?

Não existem respostas universais, não existe um sistema de coleta e destinação final que pode ser considerado universal e aplicável a toda e qualquer situação. O acondicionamento adequado do lixo, um sistema de coleta e destinação final que preserve o meio ambiente, além de contribuir positivamente para a imagem do governo e da cidade, estará caminhando rumo a sustentabilidade e a melhoria da qualidade de vida da população.

Depois de coletado, o lixo poderá ter os seguintes tipos de destinação final:

\section{a) Incineração}

A incineração esta incluída dentre os processos mais onerosos de transformação do lixo. São instalações de alto custo de implantação e de manutenção e operação dispendiosa, mas apresenta a vantagem de eliminar o lixo, reduzindo-o a aproximadamente $5 \%$ do seu volume original ou $15 \%$ do seu peso (CETESB, 1998). A incineração é a solução ideal para eliminação de resíduos sólidos especiais. Além de reduzir o lixo em volume e peso, elimina os resíduos sólidos contaminados.

\section{b) Compostagem}

Conforme Kiehl (1985), pode ser definida a "compostagem" como sendo um processo de transformação de resíduos orgânicos em adubo humificado, chamado "composto". O composto é o adubo orgânico preparado pela decomposição de restos animais e vegetais que, em condições favoráveis de fermentação, conduza essas matérias primas a um estado de parcial ou total humificação. O composto é, portanto, o resultado de um processo controlado de decomposição bioquímica de materiais orgânicos, 
transformando-os em um produto mais estável, melhor utilizado como fertilizante orgânico.

\section{c) Aterro sanitário}

Aterro sanitário é um método de disposição final do lixo sob o solo, sem que se crie no meio ambiente, incômodos ou perigos à segurança e saúde públicas, utilizando-se princípios da Engenharia para confinar o lixo à menor área possível, reduzindo-o ao menor volume verificável na prática e cobrindo-o com uma camada de terra ao fim de cada dia de operação ou a menores intervalos, se tal se fizer necessário.

O aterro sanitário, bem projetado e controlado, resolve o problema de destinação sanitária dos resíduos sólidos urbanos, além de:

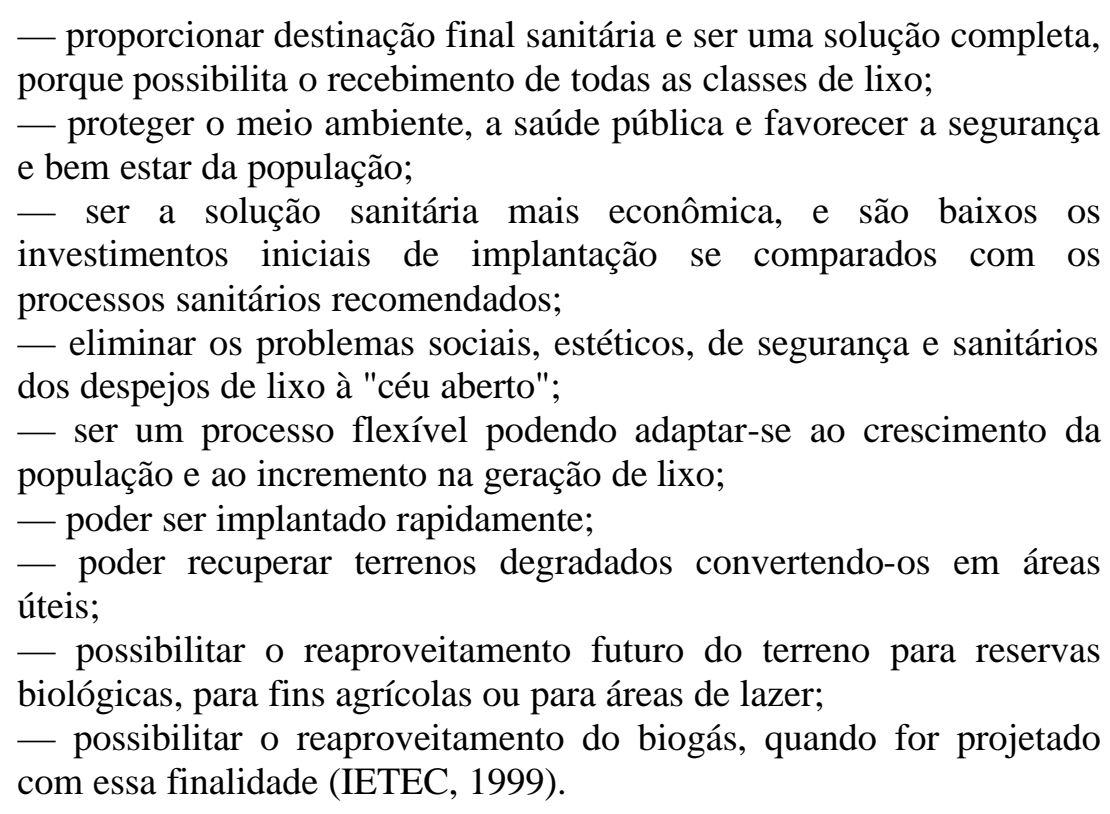

\subsubsection{O Gerenciamento integrado}

Gerenciamento Integrado de Resíduos Sólidos Urbanos é, em síntese, o envolvimento de diferentes órgãos da administração pública e da sociedade civil com o propósito de realizar a limpeza urbana, a coleta, o tratamento e a disposição final do lixo, elevando assim a qualidade de vida da população e promovendo o asseio da cidade, levando em consideração as características das fontes de produção, o volume e os tipos de resíduos, as características sociais, culturais e econômicas dos cidadãos e as peculiaridades demográficas, climáticas e urbanísticas locais. 
A Figura 2 mostra a visualização do processo em suas várias etapas constituintes.

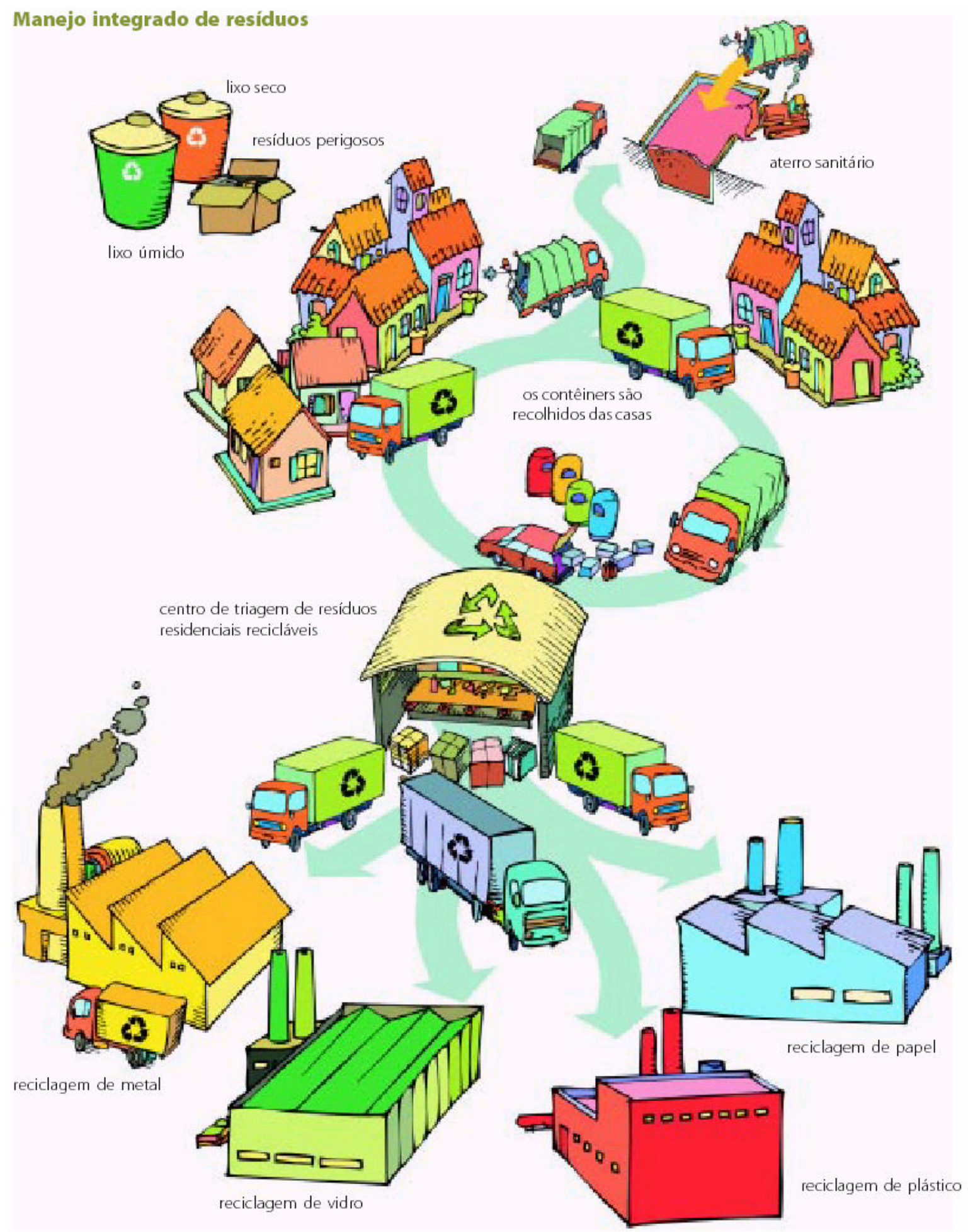

Figura 2 - Representação esquemática do Sistema de Manejo Integrado de Resíduos Fonte: Artigo técnico IDEC (idec 6 lixo) 
Segundo GRIPP (2004), usualmente são utilizados os termos "gestão de resíduos sólidos" e "gerenciamento de resíduos sólidos", sem muita distinção entre ambos, bem como do que representam. Leite (1997) apresenta em seu trabalho, uma definição para os termos gerenciamento e gestão de resíduos sólidos:

\begin{abstract}
“(...) gerenciamento de resíduos sólidos refere-se aos aspectos tecnológicos e operacionais da questão, gerenciais, econômicos, ambientais e de desempenho: produtividade e qualidade, por exemplo, e relaciona-se à prevenção, redução, segregação, reutilização, acondicionamento, coleta, transporte, tratamento, recuperação de energia e destinação final de resíduos sólidos. (...) O conceito de gestão de resíduos sólidos abrange atividades referentes à tomada de decisões estratégicas e à organização do setor para esse fim, envolvendo instituições, políticas, instrumentos e meios." (LEITE, 1997, p. 89).
\end{abstract}

Tchobanoglous (1977) mostra que as atividades gerenciais ligadas aos resíduos sólidos podem ser agrupadas em seis elementos funcionais, conforme ilustra a Figura 3.

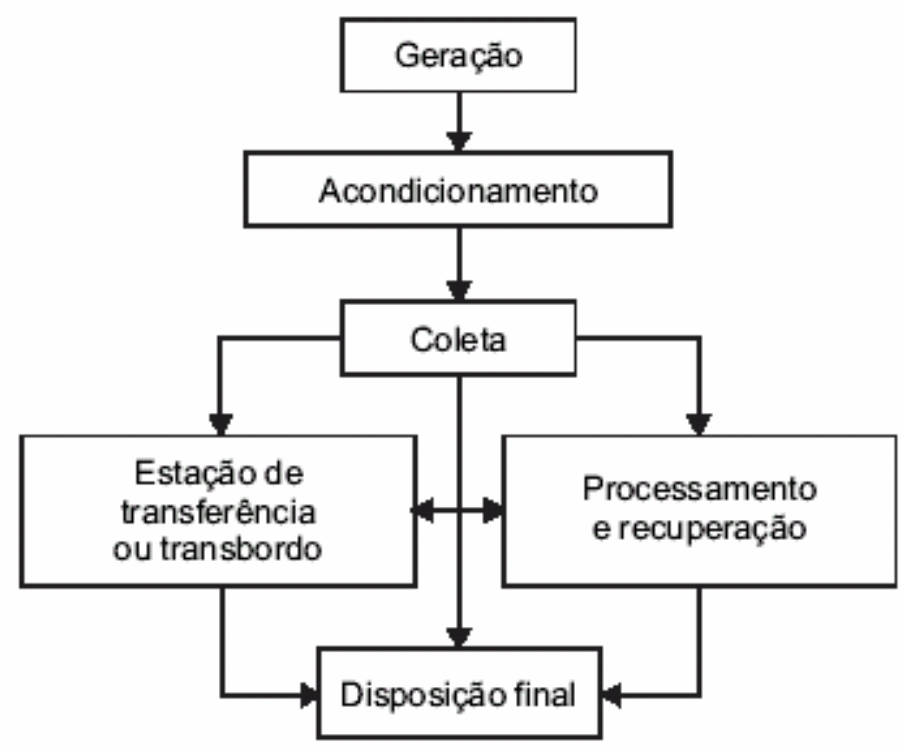

Figura 3 - O processo da coleta de resíduos sólidos e suas inter-relações. Fonte: Tchobanoglous (1977).

Numa visão mais abrangente, SCHALCH e LEITE (1998), propõem o esquema mostrado na Figura 4. 


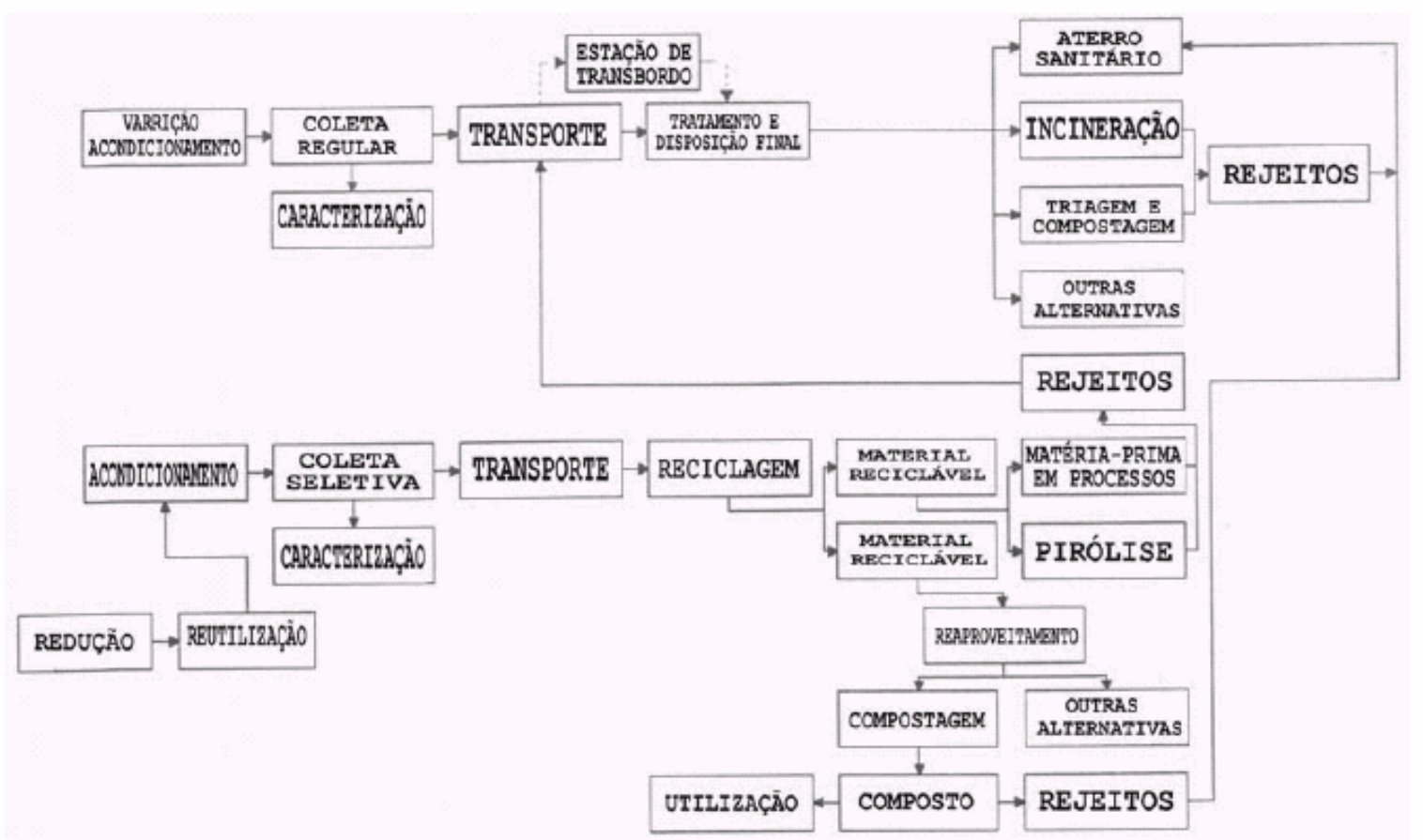

Figura 4 - Sistema de gerenciamento de resíduos sólidos domiciliares, proposto por SCHALCH e LEITE (1998).

Para tanto, as ações normativas, operacionais, financeiras e de planejamento, que envolvem a questão devem se processar de modo articulado, segundo a visão de que todas as ações e operações envolvidas encontram-se interligadas, comprometidas entre si.

Para além das atividades operacionais, o gerenciamento integrado de resíduos sólidos destaca a importância de se considerar as questões econômicas e sociais envolvidas no cenário da limpeza urbana e, para tanto, as políticas públicas - locais ou não - que possam estar associadas ao gerenciamento do lixo, sejam elas nas áreas de saúde, trabalho e renda, planejamento urbano, etc.

Em geral, diferentemente do conceito de gerenciamento integrado, os municípios costumam tratar o lixo produzido na cidade apenas como um material não desejado, a ser recolhido, transportado, podendo, no máximo, receber algum tratamento manual ou mecânico para ser finalmente disposto em aterros.

Trata-se de uma visão distorcida em relação ao foco da questão social, encarando o lixo mais como um desafio técnico no qual se deseja receita política que aponte eficiência operacional e equipamentos especializados. 
O gerenciamento integrado focaliza com mais nitidez o objetivo mais importante da questão, que é a elevação da urbanidade em um contexto mais nobre para a vivência da população, onde hajam manifestações de afeto à cidade e participação efetiva da comunidade no sistema, sensibilizada a não sujar as ruas, a reduzir o descarte, a reaproveitar os materiais e reciclá-los antes de encaminhá-los ao lixo.

Por conta desse conceito, no gerenciamento integrado são preconizados programas da limpeza urbana, enfocando meios para que sejam obtidos a máxima redução da produção de lixo, o máximo reaproveitamento e reciclagem de materiais e, ainda, a disposição dos resíduos de forma mais sanitária ambientalmente adequada, abrangendo toda a população e a universalidade dos serviços. Essas atitudes contribuem significativamente para a redução dos custos do sistema, além de proteger e melhorar o ambiente.

Finalmente, o gerenciamento integrado revela-se com a atuação de subsistemas específicos que demandam instalações, equipamentos, pessoal e tecnologia, não somente disponíveis na prefeitura, mas oferecidos pelos demais agentes envolvidos na gestão, entre os quais se enquadram:

- a própria população, empenhada na separação e acondicionamento diferenciado dos materiais recicláveis em casa;

- os grandes geradores, responsáveis pelos próprios rejeitos;

- os catadores, organizados em cooperativas, capazes de atender à coleta de recicláveis oferecidos pela população e comercializá-los junto às fontes de beneficiamento;

- os estabelecimentos que tratam da saúde, tornando-os inertes ou oferecidos à coleta diferenciada, quando isso for imprescindível;

- a prefeitura, através de seus agentes, instituições e empresas contratadas, que por meio de acordos, convênios e parcerias, exerce, é claro, papel protagonista no gerenciamento integrado de todo o sistema.

O gerenciamento integrado, portanto, implica a busca contínua de parceiros, especialmente junto às lideranças da sociedade e das entidades importantes na comunidade, para comporem o sistema. Também é preciso identificar as alternativas tecnológicas necessárias a reduzir os impactos ambientais decorrentes da geração de resíduos, ao atendimento das aspirações sociais e aos aportes econômicos que possam sustentá-lo. 


\subsubsection{O Consórcio intermunicipal}

A Constituição Federal do Brasil de 1988 (BRASIL, 2002) em seu Artigo 18, confere autonomia aos entes da organização político-administrativa da República Federativa do Brasil, que compreende a União, os Estados, o Distrito Federal e os Municípios. No artigo 23, confere competência comum a União, Estado, Distrito Federal e Municípios: “... proteger o meio ambiente e combater a poluição em qualquer de suas formas; preservar as florestas, a fauna e a flora; ...". E no Artigo 255, a Constituição prevê:

\footnotetext{
"todos têm direito ao meio ambiente ecologicamente equilibrado, bem de uso comum do povo e essencial à sadia qualidade de vida, impondo-se ao poder público e a coletividade_o dever de defendê-lo e preservá-lo para as presentes e futuras gerações".
}

A Constituição garante ao brasileiro o direito ao meio ambiente resguardado, e prevê a todos os entes federados, entre eles os municípios, o dever de zelar por este direito e autonomia para alcançar este objetivo. Mas, segundo CRUZ (2001), apesar da autonomia concedida aos municípios, isto não significa que estes disponham de recursos financeiros, materiais e humanos para a implementação de ações de proteção ao meio ambiente. Para esta autora, os municípios pequenos não possuem recursos suficientes para a implantação de serviços mais complexos, sendo dependentes em relação aos grandes municípios ou municípios-pólo. Assim, os governos locais devem assumir novos papéis e responsabilidades para mudar este quadro. De acordo com ZULAUF (2001), cabe ao município não só assumir claramente sua parte, mas também, estabelecer parcerias com os demais entes federados, principalmente outros municípios para conduzir ações voltadas ao fiel cumprimento dos preceitos constitucionais.

Com o objetivo de estudar o sistema consorciado entre municípios para a destinação de resíduos sólidos urbanos (RSU), através do levantamento de custos e análises logísticas no nível estratégico de localização de aterros e no nível operacional de roteirização e programação de frota, com a utilização de um Sistema de Informações Geográficas, NARUO (2003), desenvolveu um trabalho, onde a questão do consórcio foi amplamente investigada, trazendo enorme contribuição à pesquisa deste assunto e outros correlatos. No trabalho, a idéia principal é apresentada como: 
Têm sido difundidos no Brasil, como parcerias entre governos locais, principalmente entre pequenas e médias cidades adjacentes, sendo que a proximidade física pode determinar a viabilidade da implantação dos consórcios.

Esta difusão da cooperação ao nível de administração local se deve à necessidade de superar os desafios ocasionados pela descentralização das políticas públicas, autonomia concebida a partir da Constituição de 1988. Para alcançar o objetivo e progredir sem estar sujeito a uma esfera superior de governo, os municípios empenharam-se em racionalizar o modelo da gestão pública através da implementação de consórcios intermunicipais.

Por diversos aspectos o consórcio intermunicipal se torna atraente, principalmente para modernizar a administração pública e torná-la capaz de cumprir com suas obrigações constitucionais (NARUO, 2003, p. 25).

Considerando as cidades envolvidas com seu estudo, o autor conclui que o consórcio intermunicipal não chega a resolver todos os problemas de ociosidade de instalações e equipamentos, mas confirmou ser melhor que a solução adotada de forma isolada. Seus resultados confirmam haver uma significativa redução nos custos envolvidos ao se adotar uma solução conjunta entre os municípios.

Como conclusão final, o método desenvolvido nesta pesquisa, as ferramentas utilizadas e a solução proposta, fizeram com que se atingisse o objetivo da pesquisa, ou seja, de analisar o sistema consorciado para destinação dos resíduos sólidos e confirmá-la como alternativa melhor que a solução isolada.

Com estas conclusões, é desejável que esta pesquisa sirva de subsídio para que profissionais e pesquisadores da área desenvolvam estudos e até projetos, para auxiliar na implantação de soluções para destinação adequada de resíduos, principalmente para as cidades de pequeno porte, que sofrem com a falta de recursos financeiros e técnicos (NARUO, 2003, p. 155).

\subsection{A Importância de solucionar os problemas do lixo}

O modelo de gerenciamento ambiental não pode insistir na tese de que o crescimento econômico e a conservação ambiental são objetivos excludentes. A única maneira de se obter o crescimento econômico sustentável é a partir da conservação do meio ambiente. "Dar solução ao problema do lixo é importante sob os aspectos sanitário, ambiental, social, econômico, ecológico, pedagógico, estético e político” (IETEC, 1999, 20).

A revisão dos estudos referentes à poluição ambiental evidencia que os esforços no sentido de se desenvolver uma tecnologia adequada foram inicialmente concentrados 
nos recursos hídricos; logo em seguida nos do ar, e somente mais tarde o solo passou a ser considerado como área-problema, requerendo atenções especiais e soluções mais complexas. Pode-se encontrar na literatura especializada um número relativamente grande de excelentes trabalhos que relatam com clareza as técnicas e procedimentos utilizados no combate à poluição das águas e do ar. A intenção no momento é resumir alguns informes sobre a poluição do solo, principalmente sobre o impacto causado pelo resíduo sólido, que apesar de ser um tema muito discutido é pouco difundido (LIMA, 1991).

Para que se alcance a sustentabilidade das cidades, uma grande coordenação e integração de esforços são necessárias em vários setores, inclusive mudanças no padrão de consumo e produção. Educação adequada e a conscientização pública deverão ser reconhecidas como pilares de sustentabilidade.

A relevância sanitária na solução satisfatória de todas as fases de processamento do lixo prende-se aos aspectos de saneamento básico, com redução de impactos ambientais e, conseqüentemente, melhoria das condições de saúde pública. A importância ambiental pode ser exemplificada a partir do próprio conceito do que seja Lixo, distinguindo-o de Resíduos Recicláveis e Resíduos Reaproveitáveis. Essa distinção possibilita a formação de uma consciência ecológica em relação aos componentes recicláveis e reaproveitáveis, com valor para a preservação do meio ambiente e dos recursos não renováveis. $\mathrm{O}$ aspecto econômico, às vezes tão discutido, é ainda uma incógnita, pois o lixo não constitui riqueza a ser explorada, mas problema a ser resolvido. É pequeno o valor puramente econômico do reaproveitamento do lixo ao se comparar esse retorno de receita com os investimentos necessários para sua solução.

Têm valor econômico no lixo alguns componentes com possibilidades de reciclagem ou transformação, como:

- reciclagem de papel, papelão, plástico, vidro, metal;

- transformação de matéria orgânica do lixo em composto orgânico, através de sua industrialização;

- a produção de biogás pela decomposição da matéria orgânica, para aproveitamento do metano;

- a recuperação de entulhos para fabricação de novos materiais;

- a recuperação estrutural de terrenos inaproveitáveis pelo uso do processo de aterros sanitários;

- a produção de vapor d'água e de energia elétrica, através da incineração do lixo (IETEC, 1999, 20-21). 
Por isso o valor a ser considerado é o ecológico, pois os resíduos recicláveis retornam ao ciclo de produção como matéria prima, reduzindo consumo de energia e de recursos naturais, e a matéria orgânica, após sua transformação em compostos orgânicos, é reintroduzida no ciclo ecológico como condicionador de solos rico em húmus.

Além da reciclagem e da recuperação, reduzir a geração de resíduos é de fundamental importância para a destinação final do lixo. A introdução de novos hábitos e mudanças de comportamento da população produtora em relação à geração do lixo, neste caso, deve ser alvo a ser perseguido e, por todas as importâncias citadas, o processo de educação para a limpeza urbana e destinação final do lixo, através de projeto pedagógico e de mobilização comunitária, impulsiona o cidadão a uma participação ativa, formando uma consciência ecológica voltada para o antidesperdício.

Os conceitos modernos de gerenciamento do lixo urbano, já difundidos nos países desenvolvidos, propõem modelos de gestão descentralizados para cada tipo de resíduos e preconizam a reutilização, o reuso e a reciclagem dos mesmos, a fim de garantir economia de energia e de recursos naturais, e ao mesmo tempo, a preservação do meio ambiente e a proteção da saúde pública.

Os resíduos orgânicos poderão ser compostados e transformados em fertilizantes; os resíduos inorgânicos recicláveis poderão ser selecionados e reintroduzidos como matéria-prima ao sistema produtivo; os demais resíduos sem valor poderão ser confinados em aterros ou valas, sem que produzam danos ambientais (BRITO et al., 2000, p. 216).

Também, a busca de um maior bem estar da população encontra na solução do problema do lixo o resultado para eliminar o aspecto antiestético e desagradável à vista e ao olfato dos despejos de lixo a céu aberto. Numa comunidade onde o lixo não é retirado regularmente e com destinação adequada, é impossível garantir qualidade de vida para a população. Finalmente a destinação adequada do lixo não é apenas uma questão técnica. Como atividade pública essencial, de competência municipal, é fundamentalmente uma questão política.

De acordo com Távora Junior e Lucena (2000, p. 457):

(...) É necessário que se escolha o tipo mais adequado para a disposição de resíduos, dado o volume coletado. Uma das maneiras de analisar, do ponto de vista econômico, qual a forma de disposição 
mais adequada é através da análise dos custos de cada tecnologia, por ser esta uma das formas mais eficientes, por agregar todas as informações econômicas relevantes, entre elas os aspectos sociais e ambientais.

A destinação do lixo é um dos maiores problemas de quase todos os municípios, visto que se defrontam com a falta de recursos para investimentos na coleta e no processamento final do lixo. Os "lixões" continuam sendo o destino da maior parte dos resíduos sólidos urbanos, trazendo graves prejuízos ao meio ambiente, à saúde e a qualidade de vida da população. Mesmo nas cidades que implantaram aterros sanitários, o rápido esgotamento de sua vida útil mantém evidente o problema do destino do lixo urbano. Assim sendo, a situação exige soluções no que se refere à destinação final, e também na redução de seu volume (VAZ e CABRAL, 2000).

\subsection{Legislação ambiental}

A problemática dos resíduos sólidos é hoje um tema extremamente preocupante para as administrações municipais, estaduais e a federal e, um grande pesadelo para as comunidades. Percebe-se com clareza o avanço da legislação ambiental, principalmente a partir da constituição de 1988, em que ficam bem definidas as competências dos municípios, dos estados e da união.

Existem várias leis regendo esta matéria, cabendo à sociedade o dever de cumpri-las e, se isso não ocorrer, sanções das mais variadas espécies podem ser efetivadas. As normas de interesse geral são estabelecidas pela União, conforme disposição constitucional. Inexistindo lei federal sobre normas gerais, cabe aos estados legislar. Aos municípios compete legislar quando o assunto for de interesse local. A norma federal não é superior às normas estadual e municipal por ser federal, mas sim por ser geral. Essa norma geral federal, se invadir o campo da peculiaridade regional ou estadual, ou entrar no campo dos interesses exclusivamente locais se torna inconstitucional. A competência administrativa, o poder de polícia, ou poder-dever de polícia, como também pode ser entendido, está expresso no art. 23 da Constituição Federal. 
Relativamente ao tema resíduos sólidos, diretamente ligado às questões ambientais, nos incisos VI e VII, ela estabelece que é competência comum da União, dos Estados, do Distrito Federal e dos Municípios; no inciso VI, proteger o meio ambiente e combater a poluição em todas as suas formas; no inciso VII, preservar as florestas, a fauna e a flora. Esta competência também é repetida no art. 225, $\S 1^{\circ}$ da Constituição Federal, que afirma que todos têm direito ao meio ambiente ecologicamente equilibrado, bem de uso comum do povo e essencial à sadia qualidade de vida, impondo-se ao poder público e à coletividade o dever de defendê-lo e preservá-lo para as presentes e futuras gerações (BONATO, 1995).

A inexistência de uma definição legal é a principal responsável pela confusão que comumente se faz entre serviço público e outras instituições também de interesse coletivo, mas de natureza diversa e, portanto, insuscetíveis de concessão ou permissão, o que vem tornar imprescindível a identificação objetiva e precisa das atividades a que se refere a lei em análise, já que esta também não fornece tal conceito.

Acontece que a definição do que seja atividade específica do Estado enseja divergências insuperáveis. Aquilo que em determinado lugar considera-se atividade própria do Estado em outros lugares não pode ser assim considerado. E até em um mesmo lugar hoje pode ser considerado atividade própria do Estado àquilo que não o era ontem.

Serviço público é atividade como tal considerada pela constituição da República ou pela lei, prestada de forma permanente (ou contínua) submetida ao regime de direito público, executada concreta e diretamente pelo Estado, ou por aqueles a quem tal incumbência for delegada, visando à satisfação de necessidades, ambas de interesse coletivo. As utilidades criadas pelo exercício de serviços públicos têm natureza material, são desfrutáveis de forma direta e individualizada pelos particulares, e o regime jurídico que lhe é próprio de direito público, consagra prerrogativas de supremacia e restrições especiais (BLANCHET, 1999).

A Lei 9.074, de 07 de julho de 1995 estabelece normas para outorga e prorrogações das concessões e permissões de serviços públicos, e dá outras providências:

- Art. $2^{o}$. É vedado à União, aos Estados, ao Distrito Federal e aos Municípios, executarem obras e serviços públicos por meio de concessão e permissão de serviço 
público, sem lei que lhes autorize e fixe os termos, dispensada a lei autorizativa nos casos de saneamento básico e limpeza urbana e nos já referidos da Constituição Federal, nas Constituições Estaduais e nas Leis Orgânicas do Distrito Federal e Municípios, observados em qualquer caso, nos termos da Lei 8.987/95.

Serviço público, portanto, é toda atividade de oferecimento de utilidade ou comodidade material fruível diretamente pelos administrados, prestados pelo Estado ou por quem lhe faça as vezes, sob um regime de direito público, portanto consagrador de prerrogativas de supremacia e restrições especiais, instituído pelo Estado em favor dos interesses que houver definido como próprio no sistema normativo (MELLO, 1994). 


\title{
3. A REMUNERACÃO PELOS SERVICOS PRESTADOS
}

\subsection{A situação atual}

Em termos da remuneração dos serviços, o sistema de limpeza urbana pode ser dividido simplesmente em coleta de resíduos sólidos domiciliares (lixo domiciliar), limpeza dos logradouros e disposição final. Pela coleta de lixo domiciliar, cabe à prefeitura cobrar da população uma taxa específica, denominada taxa de coleta de lixo. Alguns serviços específicos, passíveis de serem medidos, cujos usuários sejam também perfeitamente identificados, podem ser objeto de fixação de preço e, portanto, ser remunerados exclusivamente por tarifas.

\begin{abstract}
A remuneração do sistema de limpeza urbana, realizada pela população em quase sua totalidade, não se dá de forma direta, nem os recursos advindos do pagamento de taxas de coleta de lixo domiciliar podem ser condicionados exclusivamente ao sistema, devido à legislação fiscal. Da mesma forma, a prefeitura não pode cobrar dos moradores a varrição e a limpeza da respectiva rua por ser um serviço indivisível. É preciso, portanto, que a prefeitura garanta, por meios políticos, as dotações orçamentárias que sustentem adequadamente o custeio e os investimentos no sistema. (Manual de Gerenciamento Integrado de resíduos sólidos - IBAM, 2001, p.14).
\end{abstract}

No tocante à inadimplência dos contribuintes ou usuários, são parcas as soluções legalmente possíveis para contornar a situação. Os cortes comumente adotados no fornecimento de luz ou água, pela falta de pagamento da tarifa, não podem ser aplicados na coleta ou remoção de lixo. A falta de pagamento da taxa de coleta de lixo, por exemplo, não pode ser combatida com a suspensão do serviço e do atendimento ao contribuinte inadimplente, simplesmente porque o lixo que ele dispõe para a coleta tem que ser recolhido de qualquer maneira por razões de saúde pública.

Restam, assim, poucas alternativas. Embora de aplicação legalmente duvidosa, em alguns casos é adotada a inscrição do imóvel do devedor na dívida pública do 
Município. Mesmo assim esse ato tem pouco poder punitivo, porque apenas ameaça o devedor na ocasião da eventual alienação do imóvel. O sistema de limpeza urbana, de um modo geral, consome de sete a $15 \%$ do orçamento do Município.

Há uma tendência, no país, de as prefeituras remunerarem os serviços de limpeza urbana através de uma taxa, geralmente cobrada na mesma guia do Imposto Predial e Territorial Urbano - IPTU -, quase sempre usando a mesma base de cálculo, que é a área do imóvel.

Essa é uma prática inconstitucional, que vem sendo substituída por diversas outras formas de cobrança, não havendo ainda um consenso quanto à maneira mais adequada de fazê-lo. Só mesmo uma reforma tributária poderá instrumentalizar os municípios a se ressarcirem, de forma socialmente justa, pelos serviços de limpeza urbana prestados à população.

\subsection{Modelo de cobrança através de taxa}

Os serviços e coleta e destinação final dos resíduos sólidos domiciliares são, por força legal, de responsabilidade do poder público municipal. Esta atribuição, em geral, tem sido desempenhada ou pelas próprias prefeituras ou através de empresas públicas municipais, que terceirizam ou não os serviços de limpeza pública.

\subsubsection{Conceito de taxa}

Enquanto o imposto é uma espécie de tributo cujo fato gerador não está vinculado a nenhuma atividade estatal específica relativa ao contribuinte, a taxa pelo contrário, tem seu fato gerador vinculado a uma atividade estatal específica ao contribuinte. A maioria dos autores ensina que a taxa corresponde ou está ligada a uma atividade estatal específica relativa ao contribuinte.

Conforme Machado (2000), “taxa é um tributo vinculado. A primeira característica da taxa, portanto, é ser um tributo cujo fato gerador é vinculado a uma atividade estatal específica relativa ao contribuinte. Esta característica a distingue do imposto, entretanto não basta para sua identificação específica, porque também a contribuição de melhoria 
tem seu fato gerador vinculado a atividade estatal específica". Acrescenta-se pois, que a taxa é vinculada ao serviço publico, ou ao exercício do poder de polícia. "É o tributo exigível em razão do exercício do poder de polícia ou pela utilização efetiva ou potencial de serviços públicos específicos e divisíveis, prestados ao contribuinte ou postos à sua disposição" (CASSONE, 1999, p. 75).

E no art. 77 e 79, do Código Tributário Nacional:

Art. 77. As taxas cobradas pela União, pelos Estados, pelo Distrito Federal ou pelos Municípios, no âmbito de suas respectivas atribuições, têm como fato gerador o exercício regular do poder de polícia, ou a utilização, efetiva ou potencial, de serviço público específico e divisível, prestado ao contribuinte ou posto à sua disposição.

Parágrafo único. A taxa não pode ter base de cálculo ou fato gerador idênticos aos que correspondam a imposto (MACHADO, 2000).

Art. 79. Os serviços públicos a que se refere o artigo 77 consideramse:

I - utilizados pelo contribuinte:

a) efetivamente, quando por ele usufruídos a qualquer título;

b) potencialmente, quando, sendo de utilização compulsória, sejam postos à sua disposição mediante atividade administrativa em efetivo funcionamento;

II - específicos, quando possam ser destacados em unidades autônomas de intervenção, de unidade, ou de necessidades públicas;

III - divisíveis, quando suscetíveis de utilização, separadamente, por parte de cada um dos seus usuários (CASSONE, 1999, p. 81).

Assim, para que se possa exigir taxa dessa espécie, há necessidade de o serviço público ser utilizado efetivamente pelo contribuinte, seja a que título for. Esse tipo de serviço público haverá de ter dois requisitos cumulativos:

- utilização efetiva: quando possam ser destacados em unidades autônomas de intervenção, de utilidade ou de necessidade pública (obtenho um alvará, uma certidão, um porte de arma);

- divisível: quando suscetíveis de utilização, separadamente, por parte de cada um dos usuários (o cidadão que precisa de um alvará, uma certidão, um porte de arma) (CASSONE, 1999). 


\subsubsection{Fato gerador da taxa}

O fato gerador da taxa é sempre uma atividade estatal específica relativa ao contribuinte. Indica-o a Constituição Federal, que, embora não descreva a hipótese de incidência do tributo, estabelece o âmbito dentro do qual o legislador pode fazê-lo, e neste sentido estabeleceu que a União, os Estados, o Distrito Federal e os Municípios poderão instituir "taxas, em razão do exercício do poder de polícia ou pela utilização, efetiva ou potencial, de serviços públicos específicos e divisíveis, prestados ao contribuinte ou postos a sua disposição" (MACHADO, 2000, art. 145, inc.II). Essa mesma indicação é feita pelo Código Tributário Nacional em seu art.77.

Resulta claro do texto constitucional que na atividade estatal específica relativa ao contribuinte, à qual se vincula a instituição da taxa, pode ser: (a) o exercício regular do poder de polícia ou (b) a prestação de serviços ou colocação destes à disposição do contribuinte. Tem-se, portanto, que o fato gerador da taxa envolve sempre os conceitos de poder de polícia e de serviço público, que se situam no âmbito do Direito Administrativo. Aliás, segundo consta no livro Curso de Direito Administrativo (p. 181), “[...] não poderia mesmo ser de outro modo, pois ao Direito Administrativo cabe o disciplinamento das atividades estatais, e não há dúvida de que, tanto o exercício do poder de polícia como o serviço público, constituem atividades tipicamente estatais".

\subsubsection{Poder de polícia}

De acordo com o Código Tributário Nacional o poder de polícia é definido da seguinte forma:

Art. 78. Considera-se poder de polícia atividade da administração pública que, limitando ou disciplinando direito, interesse, ou liberdade, regula a prática de ato ou a abstenção de fato, em razão de interesse público concernente à segurança, à higiene, à ordem, aos costumes, à tranqüilidade pública, ou ao respeito à propriedade e aos direitos individuais ou coletivos.

Parágrafo único. Considera-se regular o exercício do poder de polícia quando desempenhado pelo órgão competente nos limites da lei aplicável, com observância do processo legal e, tratando-se de atividade que a lei tenha como discricionária, sem abuso ou desvio de poder (CASSONE, 1999, p.79). 


\subsubsection{Serviço público}

Para o feito de situar o problema da cobrança de taxas, pode-se entender por serviço público "toda e qualquer atividade prestacional realizada pelo Estado, ou por quem fizer suas vezes, para satisfazer, de modo concreto e de forma direta, necessidades coletivas". Não se confunde com o poder de polícia porque é sempre atividade prestacional de natureza material. Para que o serviço público possa servir como fato gerador de taxa, deve ser: (a) específico e divisível; (b) prestado ao contribuinte ou posto à sua disposição; e, finalmente, (c) utilizado, efetiva ou potencialmente, pelo contribuinte.

Não é fácil o que seja um serviço público específico e divisível. Diz o Código Tributário Nacional que os serviços são específicos quando possam ser destacados em unidades autônomas de intervenção, de utilidade ou de necessidade públicas, e divisíveis quando suscetíveis de utilização, separadamente, por parte de cada um de seus usuários (MACHADO, 2000, art. 79, inc. III).

Não obstante estejam tais definições contidas em dispositivos separados, cuida-se de duas definições inseparáveis, no sentido de que um serviço não pode ser divisível se não for específico. Não tem sentido prático, portanto, separar tais definições, como a indicar que a taxa pode ter como fato gerador a prestação de um serviço público específico ou de um serviço público divisível. Aliás, isto decorre do próprio dispositivo constitucional, que se refere a serviço específico e divisível.

Se o serviço não é de utilização compulsória, só a sua utilização efetiva enseja a cobrança de taxa. Se a utilização é compulsória, ainda que não ocorra efetivamente essa utilização a taxa poderá ser cobrada. Em qualquer caso é indispensável que a atividade estatal, vale dizer, o serviço publico especifico e divisível, encontre-se em efetivo funcionamento. Em outras palavras, é condição indispensável para a cobrança da taxa a efetiva existência do serviço à disposição do contribuinte.

De acordo com o contido no parágrafo único do art. 77 do Código Tributário Nacional, a taxa não pode ter, base de cálculo ou fato gerador, idênticos aos que correspondam a impostos. É de toda evidência que a taxa não pode ter fato gerador idêntico ao de um imposto, pois a diferença entre as duas espécies tributarias, reside na diferença da 
natureza dos respectivos fatos geradores. Assim, inteiramente desnecessária é a restrição contida no referido dispositivo legal, porquanto, com ou sem ela, nenhuma taxa poderia ter fato gerador idêntico ao de um imposto.

\subsubsection{Base de cálculo:}

As discussões acerca da distinção entre taxa e preço público ou tarifa sempre foram bem acaloradas, fato que tem propiciado a solução de diversas questões. Contudo, mesmo com o sobrevir da nova Constituição, alguns pontos ainda estão a desafiar a argúcia dos doutrinadores (CASSONE, 1999).

As taxas geralmente são estabelecidas em quantias prefixadas. Não se há de falar, nestes casos, de base de cálculo, nem de alíquota. Mas pode ocorrer que o legislador prefira indicar uma base de cálculo e uma alíquota. Pode ainda ocorrer que a determinação do valor da taxa seja feita em função de elementos como, por exemplo, a área do imóvel, como acontece com a taxa de licença para localização de estabelecimento comercial ou industrial. Nestes casos, é possível dizer-se que o calculo é feito mediante aplicação de alíquota especifica. Mesmo não dispondo de critério para o exato dimensionamento da maioria das taxas, especialmente daquelas cujo fato gerador é o exercício do poder da policia, é razoável o entendimento pelo qual o valor da taxa há de ser relacionado ao custo da atividade estatal à qual se vincula. A não ser assim, a taxa poderia terminar sendo verdadeiro imposto, na medida em que o seu valor fosse muito superior a esse custo (MACHADO, 2000).

\subsection{Modelo de cobrança através de tarifa}

Para a contemplação e cobertura dos custos dos serviços prestados, a remuneração pela prestação dos serviços de limpeza pública poderá ser efetuada por meio de cobrança de tarifa, mas somente mediante a hipótese concessão ou permissão do serviço.

A Constituição, no parágrafo único do art. 175, diz que será a dispor sobre o regime das empresas concessionárias e permissionárias de serviços públicos, sobre a política tarifária etc. E, como tudo se faz em virtude de lei (art. $5^{\circ}$, II), não é o Poder Executivo a dizer que tal ou qual serviço está sujeito a esta ou àquela exação, mas a lei - que por 
sua vez deve dispor conforme a diretriz constitucional (CASSONE, 1999, p. 84).

É esse o critério jurídico que entende-se adequado, extraído, pelos fundamentos citados, de um conjunto normativo-sistemático composto de preceitos constitucionais e infraconstitucionais, qual seja, exame em face de princípios constitucionais e normas ordinárias reguladoras (CASSONE, 1999).

E o Art. $9^{\circ}$, da Lei No 8.987/95:

Art. $9^{\circ}$ A tarifa do serviço público concedido será fixada pelo preço da proposta vencedora da licitação e preservada pelas regras de revisão previstas nesta lei, no edital e no contrato.

$1^{\circ}$ A tarifa não será subordinada à legislação específica anterior.

$2^{\circ}$ Os contratos poderão prever mecanismos de revisão das tarifas, a fim de manter-se o equilíbrio econômico-financeiro.

$3^{\circ}$ Ressalvados os impostos sobre a renda, a criação, alteração ou extinção de quaisquer tributos ou encargos legais, após a apresentação da proposta, quando comprovado seu impacto, implicará a revisão da tarifa, para mais ou para menos, conforme o caso.

$4^{\circ}$ Em havendo alteração unilateral do contrato que afete o seu inicial equilíbrio econômico-financeiro, o poder concedente deverá restabelecê-lo, concomitantemente à alteração (MACHADO, 2000).

Em torno destas Leis existe necessidade de algumas definições mais amplas para bom entendimento futuro da cobrança de tarifa no serviço público.

\subsubsection{Tarifa}

Blanchet (1999) alerta que o vocábulo tarifa, a rigor, não seria sinônimo da expressão preço público, pois, o vocábulo tarifa designa uma tabela de preços, e não os próprios preços. Na prática, entretanto, nada impede o uso das duas definições como sinônimos. O que não se pode confundir é taxa e tarifa. Tarifa envolve contraprestação, retribuição, de natureza contratual, daí o caráter facultativo do preço público, a liberdade de escolha do usuário.

Quando se refere a preços públicos, a Constituição fala em "política tarifária" referindose aos serviços públicos delegados por concessão ou permissão, serviços esses que também são públicos, específicos e divisíveis, tal como exigido para as taxas. Ante isso, 
há necessidade de saber-se quando estão sujeitos a uma exação e quando à outra, tendo em vista que os efeitos jurídicos que desencadeiam são bem diferenciados.

\subsubsection{Valor da tarifa}

Para uma melhor compreensão no que se refere ao valor da tarifa, torna-se relevante a definiçãa de Blanchet (1999). A tarifa a ser paga pelo usuário do serviço corresponderá ao valor cotado pelo concessionário na proposta com a qual foi vencedor da licitação correspondente. O valor da tarifa não é imutável, podendo ser objeto de reajuste ou de revisão. O reajuste corresponde aos acréscimos resultantes das variações dos preços dos insumos necessários à prestação do serviço, calculando-se mediante aplicação de fórmula que também deverá estar prevista no mesmo contrato (BLANCHET, 1999).

A revisão, embora possa derivar-se também de oscilações nos preços dos insumos, não se subordina a uma periodicidade contratualmente prevista, pois ocorre somente quando tal oscilação é imprevisível. A revisão pode também resultar de outros fatores que venham a afetar a equação econômico-financeira do contrato de concessão, tal como ocorre com os demais contratos administrativos, desde que o motivo do desequilíbrio econômico-financeiro seja superveniente à apresentação da proposta, não provocada, imprevisível e inevitável pela parte interessada na revisão, geral e objetiva (de tal natureza que atingiria da mesma forma o contrato qualquer que fosse o concessionário), e gerador de extraordinária onerosidade para uma das partes (eventuais perdas ordinárias não excessivas compensam-se com ganhos que também acabam se verificando no transcorrer da vigência contratual).

A lei utiliza-se única e genericamente do termo revisão, mas em verdade trata também do reajuste. O direito à revisão, é reconhecido ao concessionário independentemente de previsão no edital ou no contrato, pois se funda na imprevisibilidade. Quando, pois o art. $9^{\circ}$ alude a "regras de revisão previstas nesta Lei, no edital e no contrato", está englobando na mesma denominação às duas figuras distintas: revisão e reajuste. Como ambos, revisão e reajuste, podem ser aplicados à tarifa, e objetivam também ambos, a manutenção do equilíbrio econômico-financeiro, torna-se necessário discerni-los. 


\subsubsection{Legislação municipal para a cobrança de tarifa}

Uma saída prática, para se obter uma arrecadação a altura referente ao serviço de coleta transporte e destinação final dos resíduos sólidos urbanos, pode ser a concessão dos serviços, sendo que a cobrança da tarifa, se viabilizaria através de uma Lei Municipal prévia que autorizaria a concessionária a fazer a arrecadação (MACHADO, 2000).

Modelo de Concessão dos Serviços Públicos:

- Planejamento e controle são responsabilidades do Poder Público;

- Prestação dos serviços é de responsabilidade do concessionário;

- Investimentos em meios e infraestrutura são de responsabilidade do concessionário;

- A remuneração se dá pela cobrança da tarifa.

As tarifas podem ser calculadas em função de dimensão, população, topografia, industrialização em cada um dos municípios, além dos custos de operação e manutenção de pessoal e equipamentos.

As tarifas calculadas podem representar valores médios que seriam objeto de negociação com os Poderes Executivos Municipais, e posterior aprovação em Câmara pelos Poderes Legislativos Municipais. Atingido este objetivo, a próxima etapa, englobaria a implantação de uma política tarifária que estabelecesse classes e valores diferenciados, de acordo com a geração de resíduos e da atividade do gerador. A tarifa seria composta de duas parcelas distintas: fixa e variável. A cobrança pode ser feita diretamente dos usuários dos serviços, na conta de água, luz ou telefone, conforme modelo de talão de cobrança: para que a cobrança da tarifa se viabilize, é necessário que haja uma Lei Municipal prévia que autorize a concessionária a fazer a arrecadação de acordo com o modelo a seguir.

Minuta de Projeto de Lei $N .^{\circ} \ldots$ número do PL...

Altera o Código Tributário Municipal e estabelece a forma e base de cobrança dos serviços de coleta tratamento e destinação final de resíduos sólidos municipais.

Art. $1^{\circ}$ Os serviços de coleta, tratamento e destinação final de resíduos sólidos urbanos passam a ser cobrados dos usuários sob o regime de tarifa.

$\S 1^{\circ}$ A tarifa será cobrada dos usuários que receberem os serviços prestados pela concessionária destes, nas condições estabelecidas pela 
Lei $\mathrm{N}^{\mathrm{o}}$... Número ... (Lei que autoriza o Executivo Municipal a outorgar a concessão dos serviços de coleta, tratamento e destinação final de resíduos sólidos urbanos) e pela Lei $\mathrm{N}^{\circ} \ldots$ Número ... (Lei que estabelece as condições gerais da prestação dos serviços no Município).

Art. $2^{\circ}$ - A base de cobrança da tarifa será o peso de resíduos produzido pelos usuários dos serviços.

$\S 1^{\circ}$ Os usuários serão divididos nas categorias residencial e não residencial, conforme o tipo de uso do imóvel que ocuparem.

Art. $3^{\circ}$ - Esta Lei entrará em vigor na data de sua publicação, revogadas as disposições em contrário.

\subsection{Constitucionalidade da cobrança de taxa de limpeza pública}

O Poder Judiciário, sistematicamente, vem considerando inconstitucional, em diversos municípios, a cobrança da taxa de limpeza publica agregada ao IPTU (Imposto Predial e Territorial Urbano) que utiliza como base de calculo o $\mathrm{m}^{2}$ (metro quadrado) de área construída das edificações.

Tal inconstitucionalidade decorre do fato de que como o lixo é comprovadamente gerado pelo consumo de cada habitante, então se existem várias pessoas morando em uma área construída hipotética e na área ao lado de iguais dimensões exista apenas uma pessoa, o pagamento do IPTU referente à Limpeza Pública não pode ser o mesmo. A alegação é embasada no Art.145, da CF na qual não existe base de cálculo própria.

\subsection{O Gerenciador dos resíduos sólidos urbanos e suas dificuldades no gerenciamento}

Por ser uma atividade essencial de competência local, os resíduos sólidos urbanos domiciliares têm como gerenciador o poder público municipal.

De modo geral, salvo raras exceções, a situação da limpeza urbana nos municípios que a executam diretamente não é boa. Os baixos salários, a rotatividade de pessoal, a falta de capacitação profissional, a indisponibilidade de instrumentos de controle e gerenciamento, a morosidade habitual dos processos de aquisição e suprimento de pecas, materiais e ferramentas, as influências políticas, a fragilidade institucional, a permanente falta de recursos, especialmente para fazer frente aos investimentos, e principalmente a ausência de decisão política, fazem com que os serviços sejam mal executados, sem planejamento, com baixa produtividade e altos custos (PENIDO, 1997). 
A falta de conscientização da população, em geral, faz com que o indivíduo gerador e o Estado não assumam nenhuma responsabilidade sobre esse problema, que está relacionado diretamente com o crescimento constante da população, exigindo mais produção e industrialização de alimentos e de matérias primas, transformando-as em produtos industrializados, contribuindo assim, para o aumento dos resíduos sólidos, com consequiências desastrosas para o meio ambiente e para a qualidade de vida da coletividade.

Esse assunto acaba ficando todo ao encargo dos municípios, que na grande maioria, não tem condições financeiras e econômicas, técnicas de recursos humanos capacitados para dar um atendimento adequado aos serviços de varrição, coleta, transporte, tratamento e destinação final aos resíduos sólidos em geral, e além disso o agravamento natural provocado pela falta de hábitos higiênicos e de conhecimento da população sobre a matéria (TÁVORA e LUCENA, 2000).

\subsection{Sustentabilidade financeira e ônus político}

Os resíduos sólidos urbanos se constituem em um dos mais sérios problemas ambientais enfrentados ultimamente pelas várias administrações municipais, pois os municípios brasileiros não possuem um sistema de gerenciamento adequado a seus resíduos sólidos, o que dificulta mais ainda a solução para os problemas que a má disposição desses resíduos trazem para a saúde pública (TÁVORA e LUCENA, 2000).

O fraco desempenho é causado pelas dificuldades burocráticas características da administração direta no gerenciamento de um setor operacional com grande impacto sobre a opinião pública como o da limpeza pública, o qual exige agilidade nas tomadas de decisão. O que não ocorre na administração pública, tendo em vista os baixos salários, a rotatividade de pessoal, a falta de capacitação profissional, a indisponibilidade de instrumentos de controle e gerenciamento, a morosidade habitual dos processos de aquisição e suprimento de peças, materiais e ferramentas, as influências políticas, a fragilidade institucional, a permanente falta de recursos, especialmente para fazer frente aos investimentos e principalmente a ingerência política, fazem com que os serviços sejam mal executados, sem planejamento, com baixa produtividade e altos custos. 
Adicionalmente os gastos necessários para melhorar este cenário são expressivos e enfrentam problemas institucionais e de jurisdição, de competência do poder público, pois há inúmeras ações impetradas pelas promotorias públicas pelo Brasil, questionando a constitucionalidade da cobrança da taxa de lixo. São questões como a base de cálculo, a cobrança vinculada, a divisibilidade, entre outras que têm levado à uma queda de braço entre prefeituras e promotorias cujo único perdedor é o cidadão.

Pois a dificuldade das administrações municipais em conseguir a sustentabilidade financeira dos serviços de coleta e disposição de resíduos sólidos domiciliares é potencializada em função das formas de cobrança usualmente empregadas. Há uma necessidade premente do desenvolvimento de modelos de cobrança mais eficientes, que contemplem as especificidades do gerenciamento de resíduos sólidos e a realidade técnico-operacional do município, que sirvam como instrumento econômico na redução da geração de resíduos e que estejam adequados às limitações e "lacunas" do arcabouço legal e tributário vigente.

Tais dificuldades encontradas pelas administrações municipais para um adequado gerenciamento dos seus resíduos sólidos, onde haja sustentabilidade financeira e ambiental do sistema, são agravadas pela ausência de uma Política Nacional de Resíduos Sólidos e pela existência de uma legislação tributária que não contempla, com a especificidade necessária, um instrumento satisfatório de cobrança para os serviços de coleta e disposição de resíduos sólidos domiciliares.

A grande dificuldade das Prefeituras está na sustentabilidade financeira porque a limpeza urbana é um dos serviços que mais oneram os cofres municipais, podendo seus custos absorver de 10 a 20\% do orçamento do município (PENIDO, 1997).

Em contrapartida, os recursos destinados à destinação final de lixo são compostos pela parcela que sobra (quando sobra alguma coisa) do orçamento municipal depois de gasto o que foi possível com a coleta e com a limpeza de logradouros. Sendo que em todo o país, os serviços de limpeza urbana são remunerados através de uma taxa, geralmente cobrada na mesma guia do Imposto Predial e Territorial Urbano - IPTU.

A receita proveniente desta taxa é recolhida ao tesouro municipal, nada garantindo, portanto, sua aplicação no setor. De qualquer forma, representa normalmente apenas um 
percentual dos custos reais dos serviços, advindo daí a necessidade de aportes complementares de recursos por parte das Prefeituras. Sendo que a atualização ou correção dos valores da taxa, dependem da autorização da Câmara dos Vereadores, que de um modo geral não vê com bons olhos o aumento da carga tributária dos munícipes. Além disso, a aplicação de uma taxa realista e socialmente justa, que efetivamente cubra os custos dos serviços, ainda que dentro do princípio de quem pode mais paga mais, implica em um ônus político que nem sempre os Prefeitos estão dispostos a assumir.

O resultado desta política é desanimador: ou os serviços de limpeza urbana recebem menos recursos do que o necessário, ou o tesouro municipal tem que desviar o montante de outros setores essenciais, como a saúde e educação, para execução dos serviços de coleta, limpeza de logradouros e destinação final do lixo. Dessa forma, em qualquer das hipóteses, fica prejudicada a qualidade dos serviços prestados e o círculo vicioso não se rompe: a limpeza urbana é mal realizada, pois não dispõe de recursos necessários e a população não aceita um aumento das taxas por não ser brindada com serviços de qualidade. E mais uma vez, só uma decisão política do Prefeito pode mudar o quadro, desde que esteja disposto a arcar, durante algum tempo, com o ônus de um aumento da carga tributária, até que o quadro reverta com a melhoria da qualidade dos serviços prestados (PENIDO, 1997).

O que acontece hoje na prática na grande maioria dos municípios brasileiros é que as taxas cobradas anualmente junto ao Imposto Predial e Territorial Urbano (IPTU) não geram receita para fazer frente às despesas oriundas dos serviços de coleta e disposição final, contratados ou executados pelas prefeituras municipais. Com isso a eficiência do serviço tende a cair, o sistema de coleta se torna mais escasso acarretando acúmulo de lixo nas ruas e terrenos desabitados e por fim atinge diretamente a saúde da população, causando mais gastos ainda para o município.

\subsection{Formas de cobrança - exemplos e comentários}

\subsubsection{Situação existente}

Muitos municípios têm tentado encontrar uma fórmula própria de cotizar a cobrança da taxa de coleta de resíduos sólidos urbanos, através de formulações que buscam mesclar 
os vários fatores que influenciam na formação dos custos de coleta (frequiência, padrão da edificação, bairro, área construída, testada do imóvel, etc.). Ocorre que cada município tem as suas particularidades (distribuição geográfica dos bairros, sistemas de trânsito, tipo de economia, aspectos culturais, hábitos populacionais, etc.), tornando as equações muito específicas e com aplicabilidade limitada àquela situação.

A seguir, apresentam-se algumas formas atualmente existentes de cobrança, praticadas em municípios brasileiros, de portes diferentes, onde os parâmetros determinantes das taxas estão vinculados basicamente à área construída do imóvel, ou à sua testada e ainda a algum outro fator referente ao imóvel.

\subsubsection{Cobrança da taxa de coleta em Campinas-SP.}

O município de Campinas através da Lei Municipal $n^{\circ} 5.901$ (30/12/1987), com as posteriores alterações dadas pela Lei $n^{\circ} 6355$ (26/12/1990) e suas alterações, cobra dos munícipes a taxa de Coleta, Remoção e Destinação de Lixo Urbano. Tem como base de cálculo o valor estimado da prestação do serviço, tendo como critério de rateio da Taxa os parâmetros, freqüência do serviço prestado ou posto à disposição do contribuinte; o volume da edificação (para os imóveis edificados); a testada do terreno (para os não edificados) e ainda a localização do imóvel.

Para o cálculo da taxa são feitas ainda algumas considerações. A zona urbana é dividida em duas regiões, sendo que a freqüência mínima de coleta para a Área 1 é de 301 dias por ano e para a Área 2 é de 165 dias por ano. São ainda estabelecidos os valores anuais por metro cúbico $\left(\mathrm{m}^{3}\right)$ edificado (representa uma porcentagem da UFMC - Unidade Fiscal do Município de Campinas), de acordo com a localização do imóvel e sua utilização (uso residencial ou não residencial). Para os terrenos não edificados, os valores anuais (em \% da UFMC) são considerados por metro linear de testada, resultando nos valores apresentados na tabela 1 . 
Tabela 1 - Critérios para cobrança da coleta de lixo - Campinas -SP.

\begin{tabular}{|c|c|c|c|}
\hline Tipo de Imóvel & Localização & $\begin{array}{c}\text { Valor anual } \\
\text { (\% da UFMC) }\end{array}$ & Unidade a ser considerada \\
\hline Residencial & Área 1 & 4,80 & $\mathrm{~m}^{3}$ edificado \\
\hline Residencial & Área 2 & 3,60 & $\mathrm{~m}^{3}$ edificado \\
\hline Não residencial & Área 1 & 4,00 & $\mathrm{~m}^{3}$ edificado \\
\hline Não residencial & Área 2 & 3,00 & $\mathrm{~m}^{3}$ edificado \\
\hline Terreno & Área 1 & 180,00 & $\mathrm{~m}$ linear de testada \\
\hline Terreno & Área 2 & 60,00 & m linear de testada \\
\hline
\end{tabular}

\subsubsection{Comentários.}

O método descrito torna de fácil aplicação o critério adotado pela administração municipal, pois basta conhecer alguns dados do imóvel em questão para se poder calcular o valor da taxa a ser cobrada anualmente deste imóvel. Para um prédio residencial, com localização definida e área construída coletada junto ao cadastro imobiliário da Prefeitura, pode-se calcular então o valor a ser lançado juntamente com o IPTU.

Para uma verificação deste critério de cobrança, podem ser consideradas duas situações distintas de ocupação do imóvel, por exemplo, como mostrado na tabela 2.

Tabela 2 - Exemplo hipotético 1 de cálculo da Taxa de Coleta

\begin{tabular}{|c|c|c|c|c|cr|c|}
\hline $\begin{array}{c}\text { Tipo } \\
\text { imóvel }\end{array}$ & Localização & $\begin{array}{c}\mathrm{N}^{\circ} \text { de } \\
\text { moradores }\end{array}$ & $\begin{array}{c}\mathrm{m}^{3} \\
\text { edificado }\end{array}$ & $\begin{array}{c}\text { Valor a lançar } \\
\text { (\%UFMC)/ano }\end{array}$ & $\begin{array}{c}\text { Custo/morador } \\
(\% \text { UFMC)/ano }\end{array}$ & $\begin{array}{c}\text { Variação } \\
(\mathrm{A} / \mathrm{B})\end{array}$ \\
\hline Residencial & Área 1 & 4 & $300^{*}$ & 14,40 & 3,60 & $(\mathrm{~A})$ & 0,5 \\
\hline Residencial & Área 1 & 2 & $300^{*}$ & 14,40 & 7,20 & $(\mathrm{~B})$ & \\
\hline
\end{tabular}

* casas com área de $100,00 \mathrm{~m}^{2}$ de construção e pé-direito de $3,00 \mathrm{~m}$.

Da comparação nota-se uma clara distorção nos valores lançados e cobrados dos contribuintes. Ainda que utilize o volume da construção, este é um valor obtido através da área construída do imóvel, multiplicado pelo pé-direito da construção. Vale notar que nos dois casos acima, considerou-se que ambas as casas estão localizadas na área 1. Pode-se supor outra condição onde os imóveis estejam em áreas distintas, e os valores são definidos em função da freqüência de coleta para cada área, conforme a tabela 3. 
Tabela 3 - Exemplo hipotético 2 de cálculo da taxa de coleta

\begin{tabular}{|c|c|c|c|c|rr|c|}
\hline $\begin{array}{c}\text { Tipo } \\
\text { imóvel }\end{array}$ & Localização & $\begin{array}{c}\mathrm{N}^{\mathbf{0}} \text { de } \\
\text { moradores }\end{array}$ & $\begin{array}{c}\mathrm{M}^{3} \\
\text { edificado }\end{array}$ & $\begin{array}{c}\text { Valor a lançar } \\
\text { (\%UFMC)/ano }\end{array}$ & $\begin{array}{c}\text { Custo/morador } \\
\text { (\%UFMC)/ano }\end{array}$ & $\begin{array}{c}\text { Variação } \\
(\mathrm{A} / \mathrm{B})\end{array}$ \\
\hline Residencial & Área 1 & 2 & $600^{*}$ & 28,80 & 14,40 & $(\mathrm{~A})$ & 5,33 \\
\hline Residencial & Área 2 & 4 & $300^{*}$ & 10,80 & 2,70 & $(\mathrm{~B})$ & \\
\hline
\end{tabular}

* casas com áreas construídas de 200,00 m2 e 100,00 m² respectivamente, ambas com pé-direito de 3,00 m.

Nota-se outra distorção expressiva, onde o custo por morador é 5 vezes maior na $1^{\text {a }}$ situação (A). Observa-se, finalmente, que em ambos os casos, a área construída determina o valor a ser lançado, não se considerando o número de pessoas na residência. Admitindo-se a existência de uma taxa média de geração de lixo por morador, os valores poderiam expressar esta média.

\subsubsection{Cobrança da taxa de coleta em Florianópolis - SC.}

O Município de Florianópolis - SC utiliza seu Código Tributário Municipal (instituído pela Lei Municipal $n^{\circ} 805$, de 27/12/1966) e suas alterações dadas pela Lei $n^{\circ} 984$, de 16/11/1970; Lei ${ }^{\circ} 1757$, de 04/12/1980; Lei no 2010, de 28/12/1983; Lei no 2180, de 14/12/1984 e Lei n 3499, de 12/12/1990, que definem a Taxa de Coleta de Resíduos TCR.

Para o lançamento da Taxa é utilizado o Cadastro Imobiliário Municipal, sendo que a incidência somente atinge os imóveis urbanos com edificações e beneficiados pelo serviço. O recolhimento ocorre juntamente com o IPTU sendo que a base de cálculo é a área construída do imóvel, o tipo do imóvel e a freqüência de coleta.

O valor da TCR para cada contribuinte é calculado multiplicando-se a alíquota determinada de acordo com a Tabela de freqüência de coleta; o valor da Unidade Fiscal de Referência - UFIR - do mês do lançamento e a área do imóvel. A freqüência de coleta é variável, podendo ser de 1 a 7 dias na semana, e ainda existe uma divisão entre imóveis residenciais e imóveis não residenciais, como mostrado na tabela 4. 
Tabela 4 - Tabela de frequiência de coleta - Florianópolis - SC.

\begin{tabular}{|c|c|c|}
\hline \multicolumn{3}{|c|}{ Porcentagem sobre a UFIR } \\
\hline Freqüência de coleta & Imóveis residenciais & Imóveis não residenciais \\
\hline 1 & 28,31 & 42,69 \\
\hline 2 & 57,31 & 85,61 \\
\hline 3 & 85,61 & 128,31 \\
\hline 4 & 100,23 & 151,28 \\
\hline 5 & 114,85 & 171,23 \\
\hline 6 & 128,31 & 194,20 \\
\hline 7 & 142,92 & 215,08 \\
\hline
\end{tabular}

\subsubsection{Comentários.}

Neste caso, podemos considerar para análise a mesma família do caso anterior, com freqüências de coleta diferentes e teremos então os valores mostrados na tabela 5 .

Tabela 5 - Exemplo hipotético 1 de cálculo da taxa de coleta

\begin{tabular}{|c|c|c|c|r|c|}
\hline $\begin{array}{c}\text { Tipo } \\
\text { imóvel }\end{array}$ & $\begin{array}{c}\text { Freqüência } \\
\text { de coleta }\end{array}$ & $\begin{array}{c}\mathrm{N}^{\circ} \text { de } \\
\text { moradores }\end{array}$ & $\begin{array}{c}\text { Valor lançado } \\
\text { (\% UFIR)/ano }\end{array}$ & $\begin{array}{c}\text { Custo/morador } \\
\text { (\%UFIR)/ano }\end{array}$ & $\begin{array}{c}\text { Variação } \\
\text { (A/B) }\end{array}$ \\
\hline Residencial & 4 & 2 & 100,23 & $50,11 \quad(\mathrm{~A})$ & 3,50 \\
\hline Residencial & 2 & 4 & 57,31 & $14,33 \quad(\mathrm{~B})$ & \\
\hline
\end{tabular}

Novamente pode-se observar que ocorre uma distorção na cobrança, pois ela não aborda alguns parâmetros potencialmente importantes na geração do lixo a ser coletado, que seriam o número de pessoas na residência, a renda familiar, o nível cultural, entre outros aspectos, que certamente influenciam no volume de lixo gerado.

\subsubsection{Cobrança da taxa em Vista Alegre do Alto - SP.}

Tomando como exemplo um município pequeno, com população próxima a 5.000 habitantes, a taxa de limpeza pública está relacionada ao uso do imóvel (se possui construção ou não) e à sua área construída, conforme mostrado na Tabela 6 que reproduz a Tabela VI do Código Tributário Municipal. 
Tabela 6 - Tabela VI do Código Tributário de Vista Alegre do Alto - SP.

\begin{tabular}{|c|c|c|}
\hline \multicolumn{3}{|c|}{ VALORES DA TAXA DE LIMPEZA PÚBLICA } \\
\hline ATIVIDADES & $\begin{array}{l}\text { Período de } \\
\text { Incidência }\end{array}$ & $\begin{array}{c}\text { Valor da Taxa } \\
\text { em R } \$ *\end{array}$ \\
\hline $\begin{array}{l}\text { 1. Imóveis com área de terreno até } 200,00 \mathrm{~m}^{2} \\
\text { a) com construção } \\
\text { b) sem construção }\end{array}$ & anual & $\begin{array}{l}30,00 \\
15,00\end{array}$ \\
\hline $\begin{array}{l}\text { 2. Imóveis com área de terreno de } 200,01 \mathrm{~m}^{2} \text { até } \\
300,00 \mathrm{~m}^{2} \\
\text { a) com construção } \\
\text { b) sem construção }\end{array}$ & anual & $\begin{array}{l}45,00 \\
22,50\end{array}$ \\
\hline $\begin{array}{l}\text { 3. Imóveis com área de terreno de } 300,01 \mathrm{~m}^{2} \text { até } 500,00 \\
\mathrm{~m}^{2} \\
\text { a) com construção } \\
\text { b) sem construção }\end{array}$ & anual & $\begin{array}{l}65,00 \\
32,50\end{array}$ \\
\hline $\begin{array}{l}\text { Imóveis com área de terreno acima de } 500,01 \mathrm{~m}^{2} \\
\text { a) com construção } \\
\text { b) sem construção }\end{array}$ & anual & $\begin{array}{l}85,00 \\
42,50\end{array}$ \\
\hline
\end{tabular}

* valores referentes ao ano de 2.003

Numa análise simples, compatível até com o critério utilizado, pode-se notar que neste caso, mais uma vez está ocorrendo uma incoerência ou até injustiça social. O critério baseia-se na área construída do imóvel, ignorando outros parâmetros significativos relacionados à geração de lixo nas residências, como citados anteriormente, e ainda efetua uma cobrança antecipada da taxa, na medida em que o lançamento é anual e pago sem que o ano fiscal termine. O contribuinte, paga a taxa antes do serviço de coleta ser realizado.

A grande maioria dos municípios de pequeno porte (e ainda muitos dos municípios de grande porte) efetua a cobrança da taxa de coleta de lixo com critérios que fundamentalmente utilizam a área construída do imóvel como base de cálculo da referida taxa. Considerando-se os municípios brasileiros com população de até 50.000 habitantes, que representam cerca de $36 \%$ do total (1.993 municípios), a cobrança da taxa de coleta é feita juntamente com o IPTU, e a área construída do imóvel é utilizada como base de cálculo. Este fato torna valiosa a contribuição de pesquisas que busquem encontrar melhores formas de definição das cotas de cada contribuinte ou residência. 


\subsubsection{O modelo adotado pela cidade de São Paulo - SP.}

\subsubsection{A forma de cobrança proposta}

O proprietário ou locatário de cada imóvel deverá declarar em um questionário o volume estimado de lixo que produz por dia. A partir daí, a prefeitura fixará uma taxa a ser paga mensalmente. No caso de prédios, a cobrança será individual, por apartamento. O pagamento deverá ser feito no $5^{\circ}$ dia útil do mês subseqüente. Quem não pagar a taxa continuará tendo seu lixo recolhido, mas poderá ser processado judicialmente por inadimplência. Estão isentos cerca de 5\% dos domicílios de SP (150 mil), onde não existe coleta porta-a-porta.

O dinheiro arrecadado irá para o Fundo Municipal de Limpeza Urbana, administrado a princípio pela Secretaria das Finanças, e será usado exclusivamente para pagamento dos serviços de coleta, transporte e destinação final do lixo. Atualmente, uma parcela de $1 \%$ do IPTU (Imposto Predial e Territorial Urbano) é destinada a coleta do lixo, mas o dinheiro acaba no caixa geral da prefeitura São Paulo gera cerca de 15 mil toneladas por dia, sendo 12 mil toneladas de lixo doméstico.

Os valores a serem pagos pelos contribuintes estão apresentados nas tabelas 7 e 8 .

Tabela 7 - Valores cobrados em função da quantidade de lixo gerado (1)

\begin{tabular}{|l|l|}
\hline \multicolumn{2}{|c|}{ Imóveis residenciais } \\
\hline Geração por dia - (litros) & Valor a ser pago por mês - (R\$) \\
\hline Até dez litros & $\mathrm{R} \$ 6,14$ \\
\hline Entre dez e 20 litros & $\mathrm{R} \$ 12,27$ \\
\hline Entre 20 e 30 litros & $\mathrm{R} \$ 18,41$ \\
\hline Entre 30 e 60 litros & $\mathrm{R} \$ 36,82$ \\
\hline Mais de 60 litros & $\mathrm{R} \$ 61,36$ \\
\hline
\end{tabular}


Tabela 8 - Valores cobrados em função da quantidade de lixo gerado (2)

\begin{tabular}{|l|l|}
\hline \multicolumn{2}{|c|}{ Imóveis comerciais* } \\
\hline Geração por dia - (litros) & Valor a ser pago por mês - (R\$) \\
\hline Até 30 litros & $\mathrm{R} \$ 18,41$ \\
\hline Entre 30 e 60 litros & $\mathrm{R} \$ 36,82$ \\
\hline Entre 60 e 100 litros & $\mathrm{R} \$ 61,36$ \\
\hline Entre 100 e 200 litros & $\mathrm{R} \$ 122,72$ \\
\hline
\end{tabular}

* Quem gera acima de 200 litros por dia tem de contratar uma empresa cadastrada pela prefeitura e arca com todos os custos da coleta e destinação.

No caso de imóveis vazios, segundo a assessoria de imprensa da Secretaria de Serviços e Obras, mesmo com o imóvel fechado a coleta tem continuidade. Caso o imóvel esteja comprovadamente vazio, o proprietário deve lançar no guia de pagamento o valor estabelecido na faixa mínima de cobrança $(R \$ 6,14)$. Se o imóvel estiver fechado temporariamente (férias, por exemplo), a taxa a ser paga será a mesma utilizada para o primeiro lançamento, cujo valor é definido pelo proprietário.

Como forma de orientar a população, a Prefeitura elaborou uma cartilha contendo todas as orientações necessárias aos munícipes, cuja distribuição foi feita juntamente com a primeira parcela de cobrança, explicando como aferir a produção de lixo do imóvel. Um saquinho de supermercado, comumente utilizado para acondicionar resíduos domésticos, tem capacidade para cerca de cinco litros. A prefeitura calculou em $\mathrm{R} \$ 0,02$ o valor do litro de lixo.

\subsubsection{2 $\mathrm{O}$ aspecto legal}

Muita polêmica foi criada com esta forma de cobrança proposta pela prefeitura do município de São Paulo, desde a questão política, junto à bancada da oposição na Câmara Municipal, até entidades civis que questionaram na justiça a forma utilizada.

Após vários embates no campo jurídico, e considerando ainda a inconstitucionalidade da cobrança, na medida em que, no valor do IPTU (Imposto Predial Territorial Urbano), está embutido o custo dos serviços de coleta de lixo e limpeza das ruas, o prefeito eleito 
de São Paulo encaminhou no final do ano de 2005, projeto de lei à câmara municipal que extinguiu a taxa de lixo domiciliar a partir do exercício de 2006.

\subsection{Um panorama da cobrança em alguns países}

A cobrança pelos serviços de coleta e destinação de resíduos sólidos no exterior é bastante diversificada. O que se pode observar é uma notória situação de cobrar pela quantidade de lixo que cada unidade habitacional produz, ainda que esta prática não esteja disseminada entre os países desenvolvidos. Um benefício deste modelo é o efeito redutor da quantidade de lixo produzido, favorecendo ainda a reciclagem.

Atualmente, os meios mais utilizados de cobrança no exterior são aqueles que tem por base de cálculo o peso dos resíduos ou o seu volume. Em algumas comunidades dos EUA e da Europa, a forma mais utilizada é a que considera o volume de lixo gerado, sendo que em menor número, o peso é também utilizado como base de cálculo. Diversos fatores tornam este sistema difícil de ser implementado na coleta domiciliar, pois a operação é complexa e os custos de aquisição de equipamentos são elevados.

A cobrança baseada no volume de lixo também é utilizada nos EUA e na Europa, apresentando-se de formas diversas, que em resumo podem classificadas em Cobrança Proporcional, Cobrança Variável e Cobrança Mínima.

Na modalidade Cobrança Proporcional, utilizam-se sacos de lixo (denominados "Bags") com tamanhos padronizados e específicos, cuja aquisição é feita pelo munícipe junto ao administrador municipal ou pela empresa terceirizada, sendo que os custos relativos à operação do sistema já estão incorporados no valor do saco adquirido. Para controle deste sistema, somente estes sacos são coletados. Uma variante deste modelo é a venda por parte do município, de etiquetas adesivas (chamadas "Tags" ou "Stickers") que são coladas nos sacos de lixo comuns e desta forma também são coletados. O valor cobrado pela etiqueta também contempla os custos daquela coleta.

Na modalidade Cobrança Variável, utilizam-se contêineres com pagamentos feitos de acordo com o volume do contêiner ("Can") e da freqüência de coleta. O lixo excedente é cobrado à parte, sendo seu valor crescente, objetivando inibir a geração de resíduos. 
O sistema de Cobrança Mínima consiste no pagamento, juntamente com outras taxas e impostos pagos à municipalidade, de um valor fixo que assegura ao munícipe a coleta de seus resíduos, até um certo valor definido previamente.

Em algumas comunidades o usuário paga apenas pelo lixo não-reciclável ou misturado ("mixed waste"); em outras localidades, além do "mixed waste", os usuários são cobrados também pela coleta de materiais recicláveis segregados (especialmente os resíduos orgânicos).

Na União Européia e Suíça, com exceção da Grã-Bretanha, as comunidades locais têm autorização legal para efetuar a cobrança das taxas necessárias para custear o gerenciamento de resíduos da localidade. Em países como a Itália, Luxemburgo e Suíça, essa cobrança, por parte das autoridades locais, é obrigatória, conforme indicado na Tabela 7.

Tabela 9 - Existência de base legal para a cobrança de taxas de coleta de lixo por parte das autoridades locais (SPET, 1999).

\begin{tabular}{|l|l|l|l|}
\hline \multicolumn{1}{|c|}{ País } & Situação & País & Situação \\
\hline Áustria & Sim & Suécia & Sim \\
\hline Bélgica & Sim & Suíça & Obrigatório \\
\hline Dinamarca & Sim & Inglaterra & Não \\
\hline Finlândia & Sim & Itália & Obrigatório \\
\hline França & Sim & Luxemburgo & Obrigatório \\
\hline Alemanha & Sim & Holanda & Sim \\
\hline Grécia & Sim & Espanha & Sim \\
\hline Irlanda & Sim & & \\
\hline
\end{tabular}

Na Grã-Bretanha, os serviços de coleta, tratamento e disposição final de resíduos têm de ser feitos pelas comunidades, sem a cobrança de taxas específicas dos domicílios. A cobrança é proibida por lei. Entretanto, prestadores de serviços e geradores de lixo comerciais têm de pagar pela disposição final. Para os resíduos de embalagem, o usuário, geralmente, já está pagando, embutido no preço, o custo da coleta, reciclagem e destinação, quando efetua a própria compra do produto.Principalmente no sul da Europa e na maior parte da América do Norte, os custos com o gerenciamento de resíduos ainda 
são cobertos por meio de uma taxa calculada com base no tamanho da edificação, no tipo de uso do imóvel (prestação de serviços, comércio, etc.), no tamanho dos jardins, no nível de renda, etc..

Exemplos de utilização de novas formas de cobrança para os geradores domiciliares na Europa e Estados Unidos e o detalhamento de algumas delas, em localidades situadas em países europeus e nos EUA, com a verificação dos seus efeitos, são relatados a seguir.

\subsubsection{A cobrança da taxa de coleta nos Estados Unidos}

Em estudos realizados por BURGIEL et RANDALL (1988), que verificaram a existência de cobrança pelos serviços de coleta de resíduos em municípios com menos de 100.000 habitantes, observou-se que em 17\% destes municípios, é feita a cobrança com base na quantidade de lixo gerada, fato também observado em cerca de $18 \%$ dos municípios com mais de 100.000 habitantes. Dessa forma, do total de 267,5 milhões de habitantes, 35 milhões de pessoas (cerca de $13 \%$ ) viviam em cidades onde havia a cobrança da coleta e disposição do lixo domiciliar pelo sistema denominado pela EPA Enviromental Protecion- Agency - de PAYT ("Pay-as-you-throw").

Das 4.033 comunidades que adotavam o PAYT em 1998, 1843 localizavam-se no estado de Minesota, abrangendo um total de 3,8 milhões de habitantes. Nesse estado, há legislação específica que determina, no âmbito estadual, que as autoridades locais efetuem a cobrança dos serviços de coleta e disposição final do lixo pela quantidade gerada (em peso ou em volume).

As formas de cobrança nas comunidades dos EUA são similares às da Europa e variam de cidade para cidade (BAUER et MIRANDA, 1996). É utilizado tanto o sistema de venda de sacos padrão, quanto o de venda de etiquetas ou rótulos; sendo bastante utilizado, ainda, o sistema de aluguel de contêiner conforme o seu volume e a freqüência de coleta. A pesagem dos resíduos é utilizada em poucas comunidades. Diversos exemplos da aplicação do sistema PAYT são relatados por MIRANDA et al. (1995) e MIRANDA et La PALME (1997). 


\subsubsection{A cobrança da taxa de coleta na Itália}

Na Itália, o princípio do PAYT está previsto em legislação nacional (National Waste Management Act - Decree 22/97) e na regulamentação subseqüente (Technicals Regulations on Financing of MSW Collection), para ser implementado em toda a Itália dentro de poucos anos (Gripp, W.G, 2004). A legislação prevê que todos os custos dos serviços de coleta sejam partilhados pelos usuários domiciliares e também por outros, tais como artesãos, prestadores de serviços e usuários comerciais, tendo como base alguns parâmetros básicos: o tipo, a quantidade e o potencial de geração de resíduos e a qualidade do serviço (freqüência, tipo de contêiner, etc.).

Outro aspecto importante, é que também está prevista a cobrança dos serviços de limpeza em duas parcelas, sendo uma parte fixa e outra variável. A parte fixa, cobrada das residências, utiliza como parâmetros a dimensão da casa, o número de moradores e ainda no tipo da moradia (se tem jardim, se é do tipo flat, se é térrea, etc.), também nos índices de produção de resíduos, de acordo com a sua categoria estão estabelecidos na legislação vigente. Esta parte visa cobrir as despesas com a coleta dos recicláveis, a limpeza das ruas e ainda parte dos custos de coleta e transporte dos resíduos não recicláveis. A parcela variável está vinculada à quantidade (em peso ou volume) dos resíduos não recicláveis gerados, e objetiva cobrir os custos de tratamento e disposição final dos resíduos não recicláveis, bem como complementar os custos de coleta e transporte não cobertos pela parte fixa. 


\section{INSTRUMENTO DE COLETA DE DADOS}

Para a realização do trabalho, foi necessário o desenvolvimento de uma pesquisa de campo, objetivando a obtenção de dados quantitativos que expressassem com fidelidade o consumo de energia elétrica e consumo de água, vinculados à residência pesquisada, no município de Taiaçu - SP.

A realização da pesquisa está no fato de que a mesma tem se tornado um instrumento amplamente utilizado e reconhecida na maior parte dos países. Por meio de relatórios apresentados, o conceito de se considerar informações provenientes de um pequeno número de pessoas, como uma representação precisa de um número de pessoas significativamente maior, tornou-se familiar. As pesquisas têm amplo apelo, particularmente em culturas democráticas, porque são vistas como um reflexo das atitudes, preferências e opiniões próprias das pessoas das quais os responsáveis pela política recebem seu mandato. Os políticos baseiam-se fortemente em pesquisas e levantamentos da opinião pública para orientação de estratégias de campanha e no cumprimento de suas responsabilidades profissionais.

As empresas usam resultados de pesquisas para formular estratégias, programas de rádio e televisão são avaliados e planejados em grande parte de acordo com os resultados de pesquisas (REA e PARKER, 2000).

\subsection{Metodologia}

A abordagem fundamental para a realização do trabalho trata-se da parte empírica, a qual foi realizada através de entrevistas em uma amostra determinada dos domicílios urbanos. Para obtenção dos dados relevantes para a pesquisa, foram realizadas 210 entrevistas em residências, através de formulário específico, representando $14 \%$ dos domicílios do município e conferindo um coeficiente de confiabilidade de $95 \%$. As entrevistas para obtenção dos dados discutidos no trabalho foram realizadas nos meses 
de fevereiro e março do ano de 2005, sendo os dados tabulados no programa Excel e elaborados gráficos e tabelas para melhor representar as informações obtidas. Dos 210 formulários preenchidos, 10 entrevistas foram descartadas por apresentarem informações duvidosas as quais poderiam comprometer o resultado do estudo.

Tabela 10 - Exemplo de planilha de coleta de dados

PLANILHA DE COLETA DE DADOS: PESAGEM DE LIXO DOMÉSTICO
\begin{tabular}{|l|l|c|c|c|c|c|}
\hline DATA: 12/09/2004 & $\begin{array}{c}\text { Técnico: Thiago } \\
\text { SEQ. }\end{array}$ & ENDEREÇO \\
coleta & $\begin{array}{c}\text { Nonsumo de } \\
\text { na casa }\end{array}$ & $\begin{array}{c}\text { PESO (Kg) } \\
\text { quarta }\end{array}$ & $\begin{array}{c}\text { PESO (Kg) } \\
\text { sexta }\end{array}$ \\
\hline 1 & $\begin{array}{l}\text { Rua São } \\
\text { Sebastião, } 340\end{array}$ & $8: 00$ & 4 & $145-124-117-135$ & 9 & 8 \\
\hline 2 & $\begin{array}{l}\text { Av. 13 de Maio, } \\
250\end{array}$ & $9: 30$ & 3 & $120-112-118-122$ & 7,5 & 6 \\
\hline 29 & $\begin{array}{l}\text {. } \\
\text {. }\end{array}$ &. &. &. &. &. \\
\hline 30 & $\begin{array}{l}\text { Av. 15 de } \\
\text { Novembro, } 78\end{array}$ & $10: 00$ & 3 & $145-150-135-147$ & 8 &. \\
\hline
\end{tabular}

O presente estudo foi norteado pela seguinte base científica: Gil (1994), Gil (1995), Marconi e Lakatos (1996) e Silva (2001). De acordo com a proposição dos autores referidos, pode-se classificar o presente trabalho da seguinte forma:

- Do ponto de vista da sua natureza é uma pesquisa básica, pois objetiva gerar conhecimentos novos, úteis para o avanço da ciência sem necessariamente ter aplicação prática prevista;

- Quanto à forma de abordagem do problema é quantitativa, pois para serem analisadas e classificadas as informações e opiniões foram traduzidas em números e percentuais;

- Do ponto de vista de seus objetivos a pesquisa é tanto exploratória quanto descritiva;

- Exploratória porque visou proporcionar maior familiaridade com a problemática dos resíduos sólidos urbanos, através de estudo bibliográfico;

- Descritiva, pois analisou as características da população e procurou entender as relações entre as diferentes variáveis. Sendo que as informações para caracterizar a população foram obtidas através de entrevista com formulário previamente padronizado;

- Do ponto de vista dos procedimentos técnicos, é uma pesquisa bibliográfica, pois foram consultados livros, artigos de periódicos e materiais disponíveis na 
Internet. Ainda, documental porque materiais que não receberam tratamento analítico foram consultados. Levantamento, porque as pessoas cujos dados queria-se conhecer foram interrogadas diretamente;

- A pesquisa bibliográfica e documental foi desenvolvida através da contribuição de diversos autores sobre o problema, mediante consultas a livros, periódicos, revistas, leis, teses, dissertações e documentos em site's da Internet.

A pesquisa de campo caracteriza-se pela interrogação direta das pessoas cujo comportamento se deseja conhecer. Basicamente, procede-se à solicitação de informações a um grupo significativo de pessoas acerca do problema estudado. A realização de pesquisas por amostragem com formulários estruturados, gera dados padronizados, os quais permitem a quantificação, conseqüente processamento e a análise estatística. Porém, o sucesso da pesquisa está em grande parte relacionado com o processo de elaboração das perguntas.

É importante salientar que nenhum questionário ou formulário pode ser considerado ideal para obter todas as informações necessárias a um estudo. O pesquisador precisa usar de experiência e critério profissionais na construção de uma série de perguntas que maximizem as vantagens e minimizem as desvantagens em potencial.

Para o levantamento de dados foi elaborado um formulário, o qual possibilitou a realização de uma entrevista estruturada, sendo que esta se desenvolveu a partir de uma relação fixa de perguntas, cuja ordem e redação permaneceu invariável para todos os entrevistados. Por possibilitar o tratamento quantitativo dos dados este tipo de entrevista tornou-se o mais adequado. Quando a finalidade for comparar indivíduos, instituições ou comunidades, as pesquisas oferecem uma vantagem adicional, a capacidade de reprodução, ou seja, o questionário usado numa cidade ou comunidade pode ser reimplementado em outra, ou aplicado posteriormente na mesma comunidade para avaliar diferenças atribuíveis à localização ou ao tempo (GIL, 1994). 


\section{5 - RESULTADOS E DISCUSSÃO}

\subsection{Resultados obtidos}

Após a coleta dos dados da população estudada, utilizou-se a planilha Excel para tratar as informações, através de gráficos representativos das situações propostas. O objetivo do estudo compreende a verificação das relações entre os consumos vinculados à residência e a geração de resíduos sólidos domiciliares - RSD.

Os pares de valores de consumo de energia-RSD gerado, consumo de água-RSD gerado e área construída-RSD gerado foram listados e gerados então gráficos e tabelas para melhor visualização do assunto.

\subsubsection{Relação entre consumo de água e RSD gerado}

Uma das primeiras relações que foram estudadas é a que busca verificar o vínculo existente entre o consumo de água na residência e a quantidade de resíduos sólidos domiciliares gerados. Os valores obtidos com a pesquisa são apresentados a seguir, com as respectivas representações gráficas, que facilitam a visualização desta realidade. 


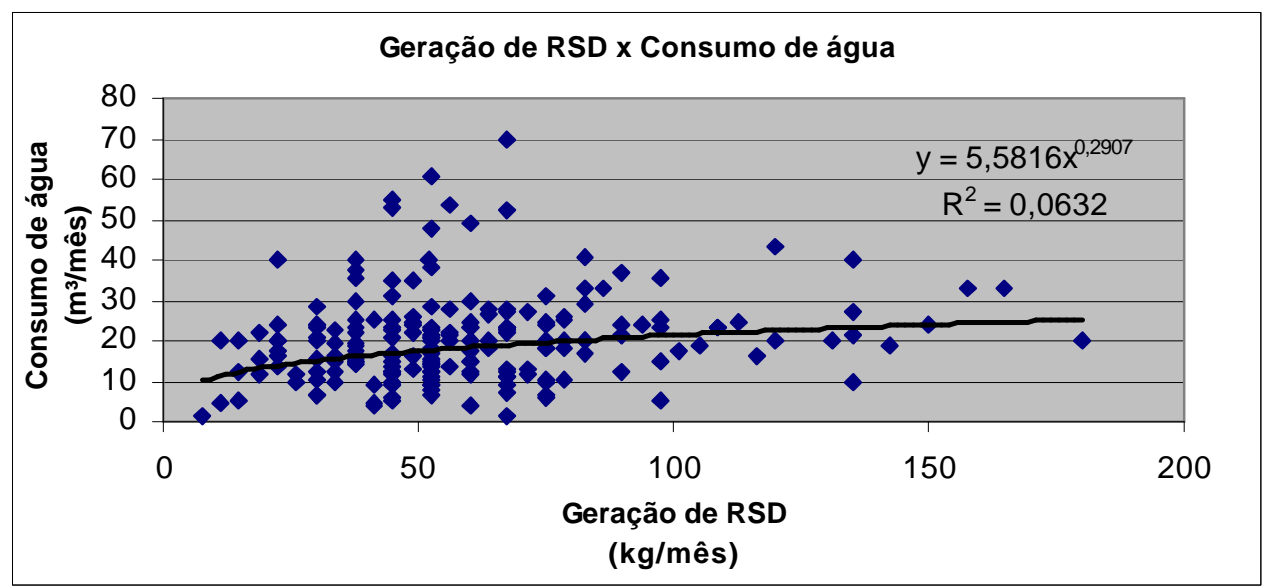

Figura 5 - Gráfico dos valores referentes ao consumo de água x quantidade de RSD gerado

A curva que melhor representou a dispersão apresentada é do tipo potencial, porém observa-se que há grande erro ( $\mathrm{R}^{2}$ pequeno). Com o intuito de verificar a possibilidade da classificação em faixas de consumo promover uma melhora expressiva na linha de tendência, elaborou-se então novas tabelas de valores, para cada faixa de consumo de água.

O objetivo, a partir da fraca representação encontrada para o universo de dados, foi verificar se trabalhando com faixas menores de consumo, poderia haver melhora expressiva na representação. À frente estão as representações obtidas para as faixas respectivas de consumo de água.

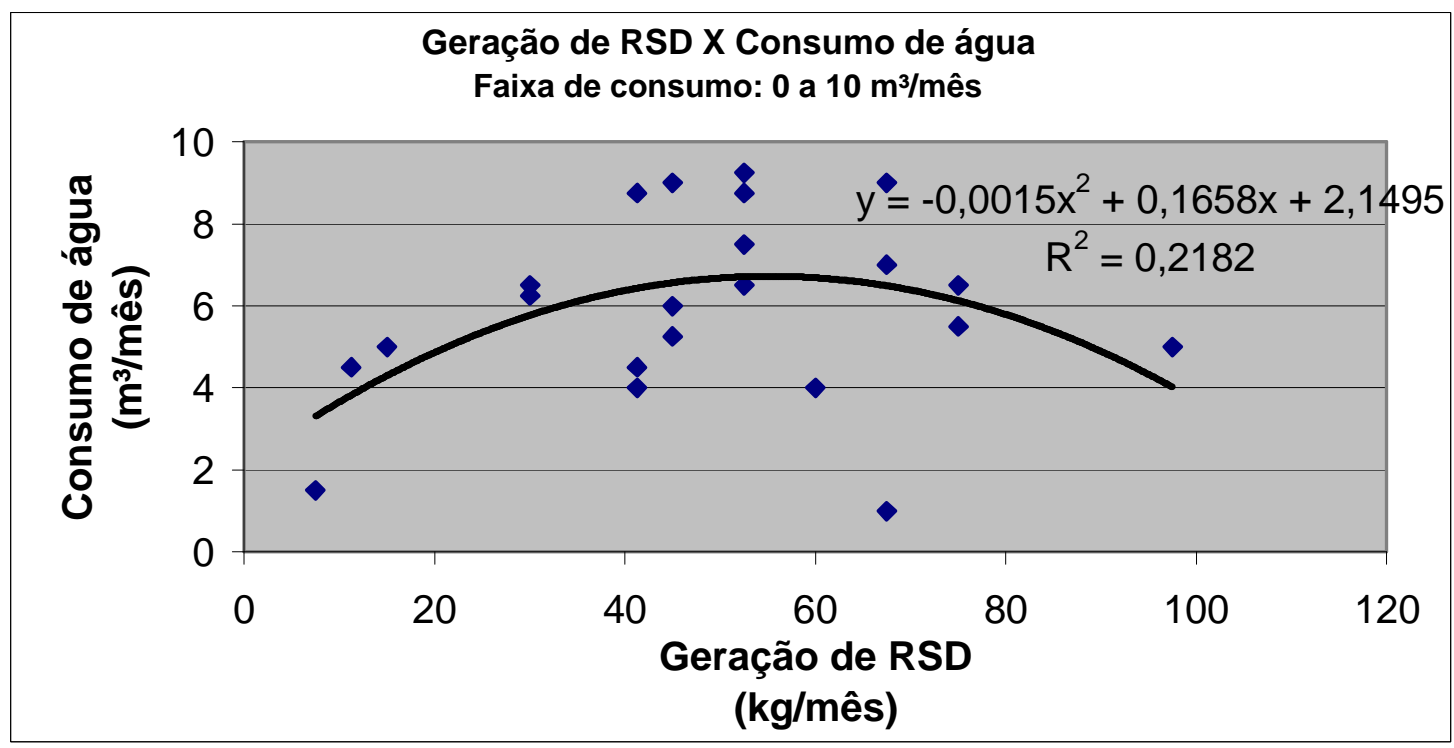

Figura 6 - Gráfico dos valores referentes ao consumo de água x quantidade de RSD gerado para faixa de consumo de 0 a 10 m³/mês. 
Como se pode observar, não houve melhora expressiva para esta faixa de consumo.

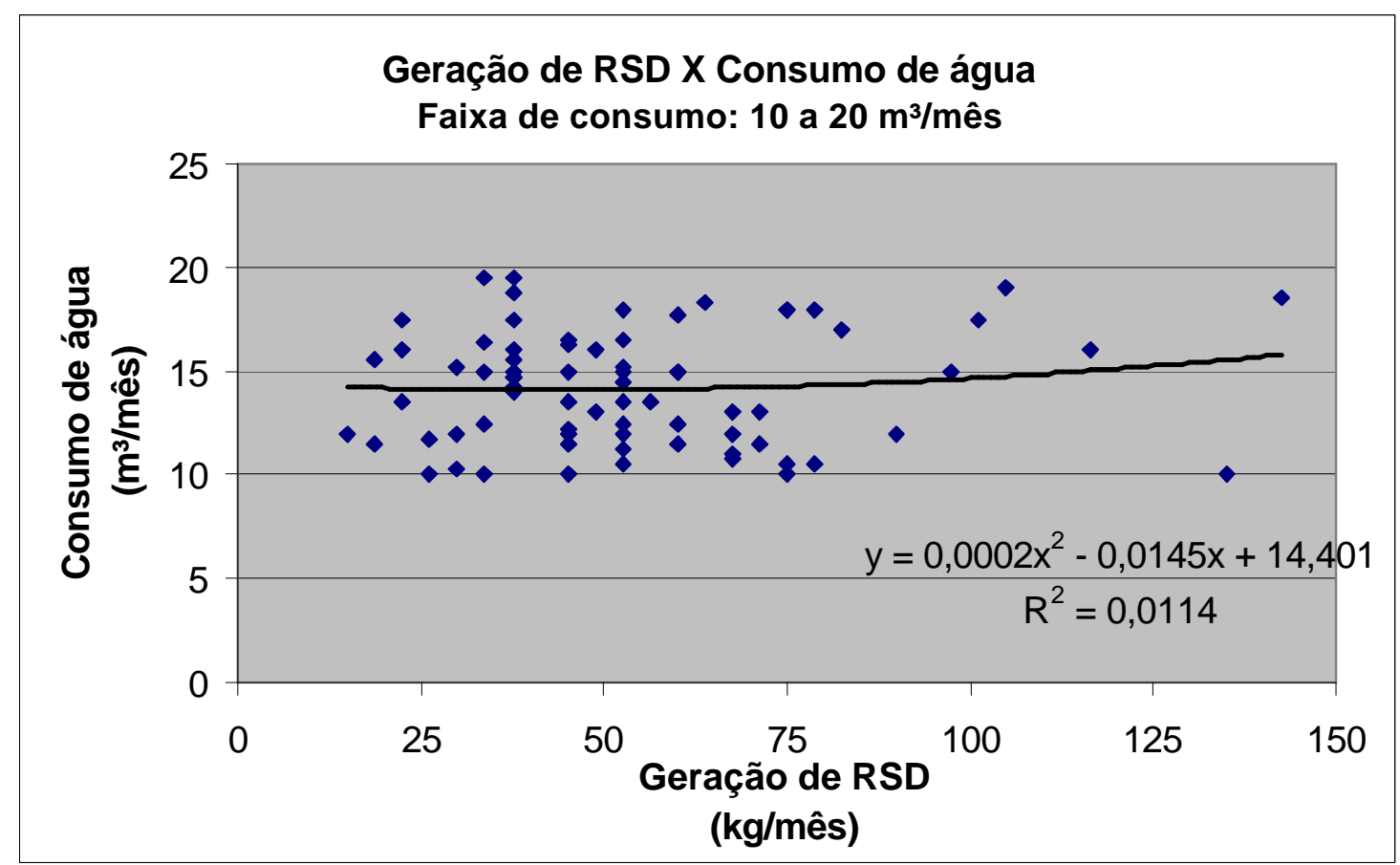

Figura 7 - Gráfico dos valores referentes ao consumo de água x quantidade de RSD gerado para faixa de consumo de 10 a $20 \mathrm{~m}^{3} / \mathrm{mês}$.

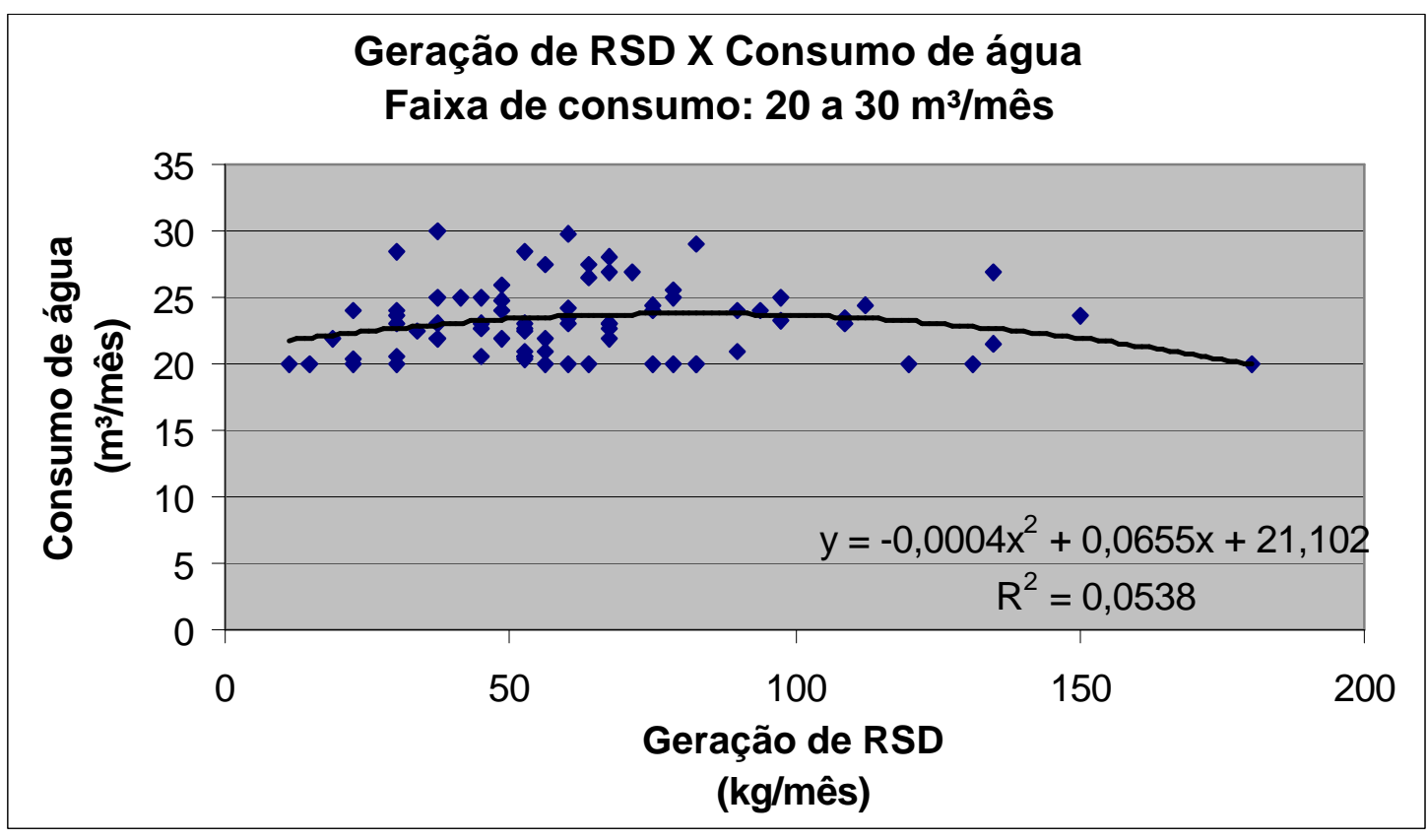

Figura 8 - Gráfico dos valores referentes ao consumo de água x quantidade de RSD gerado para faixa de consumo de 20 a $30 \mathrm{~m}^{3} / \mathrm{mês}$. 


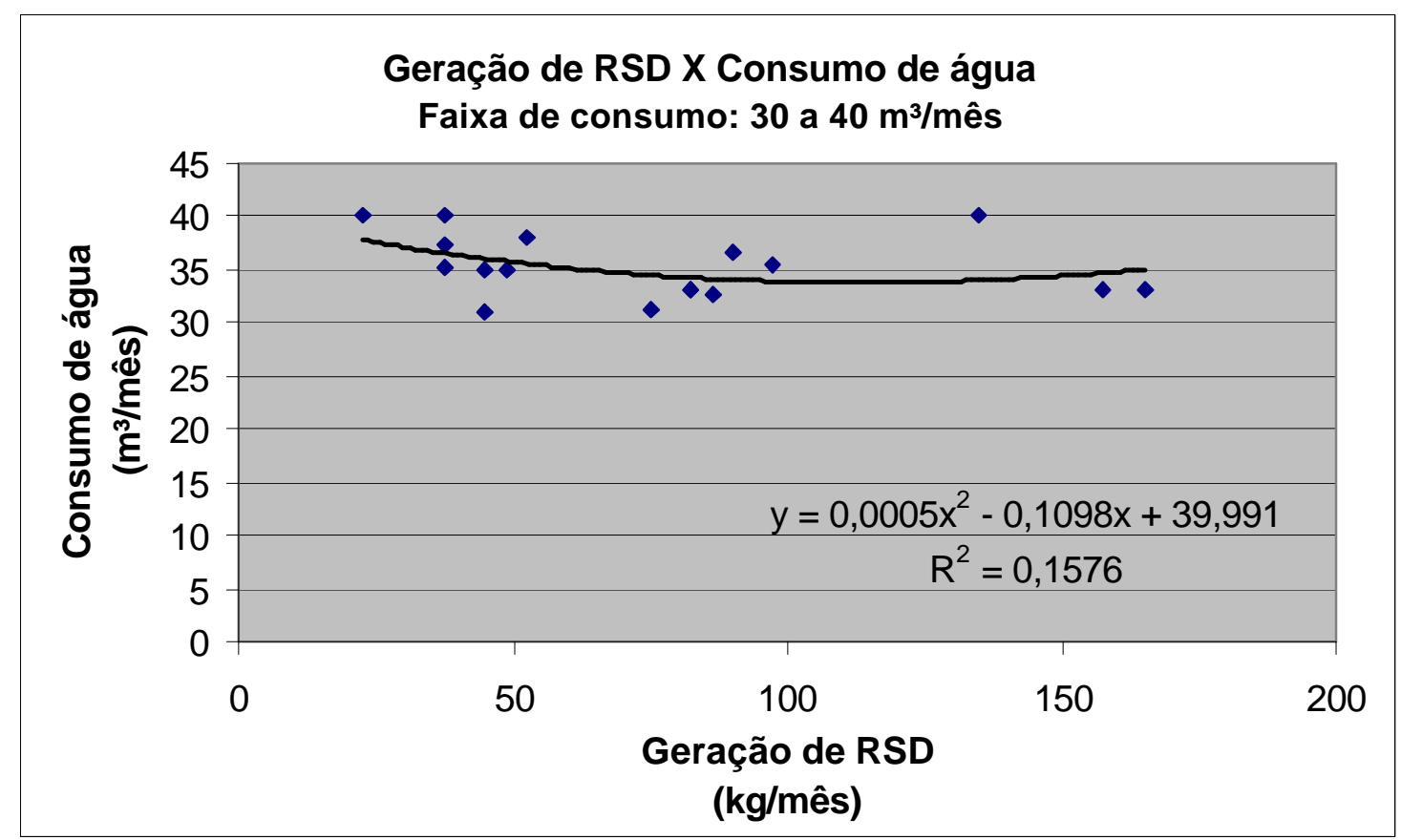

Figura 9 - Gráfico dos valores referentes ao consumo de água x quantidade de RSD gerado para faixa de consumo de 30 a $40 \mathrm{~m}^{3} / \mathrm{mês}$.

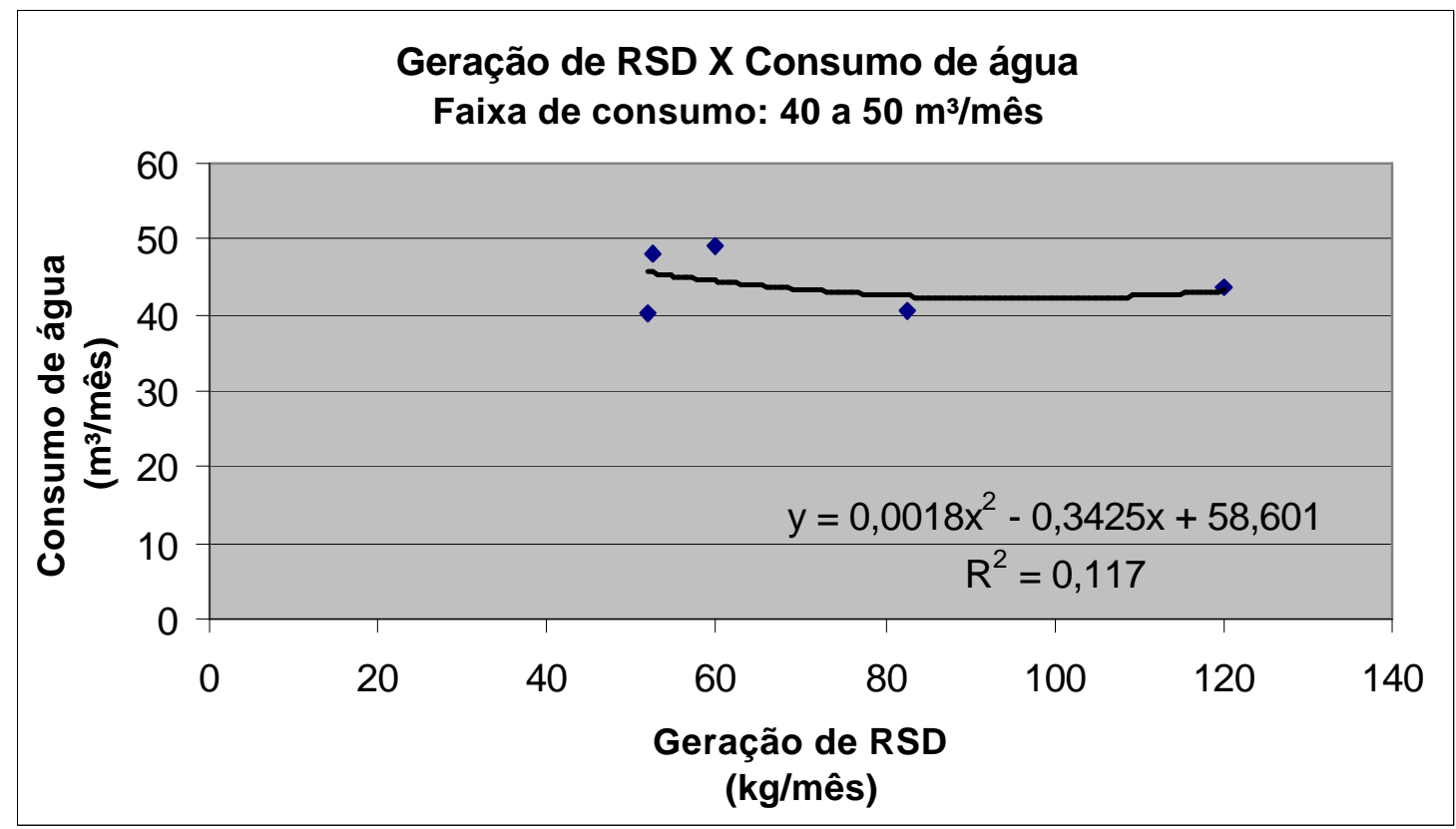

Figura 10 - Gráfico dos valores referentes ao consumo de água x quantidade de RSD gerado para faixa de consumo de 40 a $50 \mathrm{~m}^{3} / \mathrm{mês}$.

$\mathrm{Na}$ busca de verificar a possível vinculação entre o consumo de água e a geração de resíduos sólidos domiciliares, D’Elia (2000), em estudo realizado no município de Mairinque-SP., com população de 50.000 habitantes, constatou: “[...] os índices relacionais obtidos nos comprova a relação existente entre a utilização da água e a geração de resíduos sólidos domiciliares [...]”. 
Amparado por esta conclusão, buscou-se ainda estudar a relação, através da divisão por faixas de consumo que representavam o somatório de todos os consumos da faixa em questão, com o respectivo somatório das quantidades de RSD's gerados para aquela faixa, e cujos valores obtidos e a representação gráfica estão abaixo.

Tabela 11 - Valores obtidos por faixa de consumo de água

\begin{tabular}{|c|c|c|}
\hline Faixa de consumo & \multicolumn{2}{|c|}{ Total por faixa } \\
\hline (m³/mês) & Água $\left(\mathrm{m}^{3}\right)$ & RSD (kg) \\
\hline 0 A 10 & 131,25 & 1072,5 \\
\hline 10 A 20 & 1052,67 & 4001,25 \\
\hline 20 A 30 & 1736,85 & 4863,75 \\
\hline 30 A 40 & 479,5 & 1102,5 \\
\hline 40 A 50 & 341,25 & 562 \\
\hline Acima de 50 & 343,75 & 333,75 \\
\hline
\end{tabular}

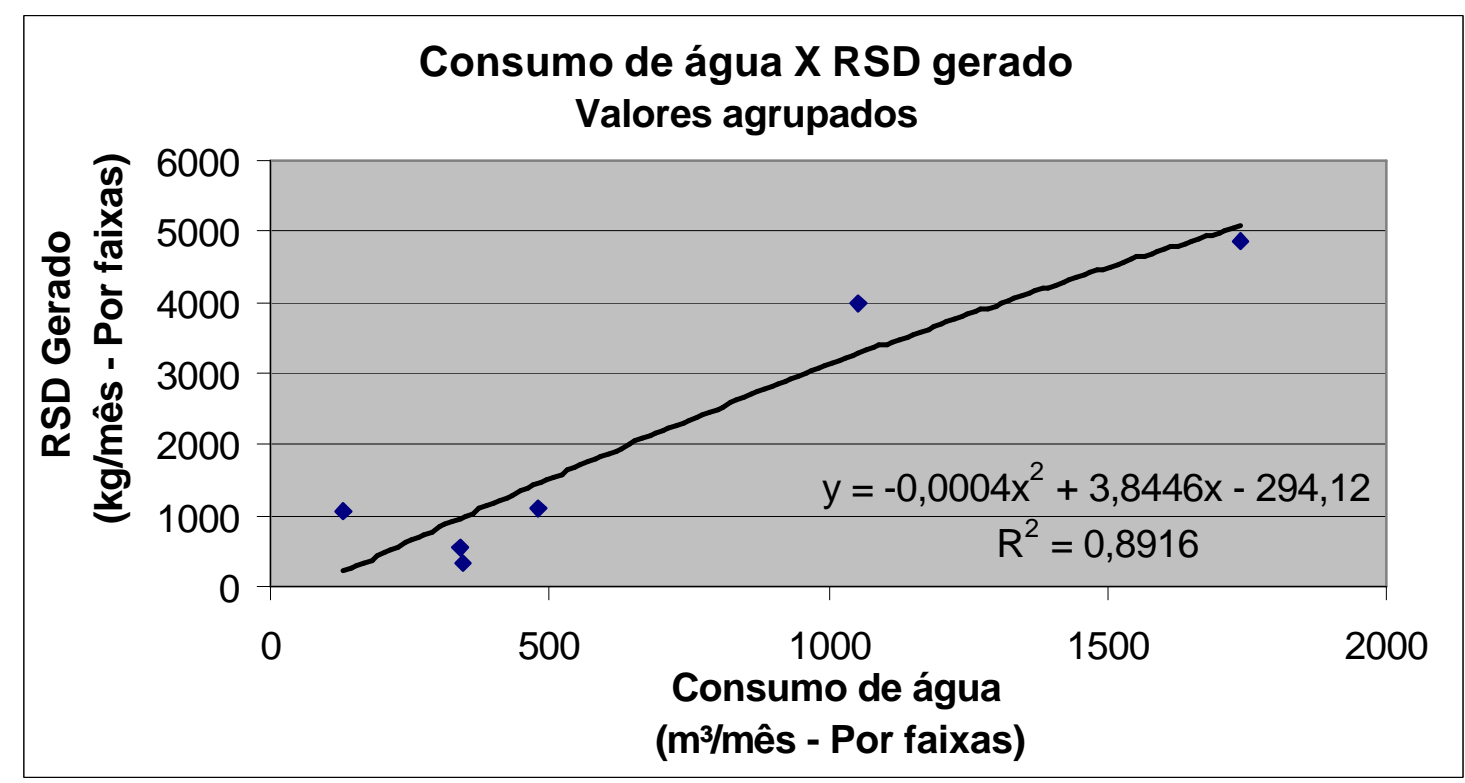

Figura 11 - Gráfico dos valores referentes ao consumo de água x quantidade de RSD gerado para faixa de consumo agrupadas (conf. Tab. 11).

Neste caso, houve grande melhora na representação proposta, com redução significativa do erro ( $\mathrm{R}^{2}$ melhor). 


\subsubsection{Relação entre consumo de energia elétrica e RSD gerado}

$\mathrm{Na}$ seqüência dos trabalhos, outra relação avaliada como relevante na análise da vinculação com a geração de RSD's é a que utiliza o consumo de energia elétrica do imóvel como parâmetro na previsão da quantidade de RSD gerado na residência. Os valores obtidos na pesquisa são apresentados a seguir.

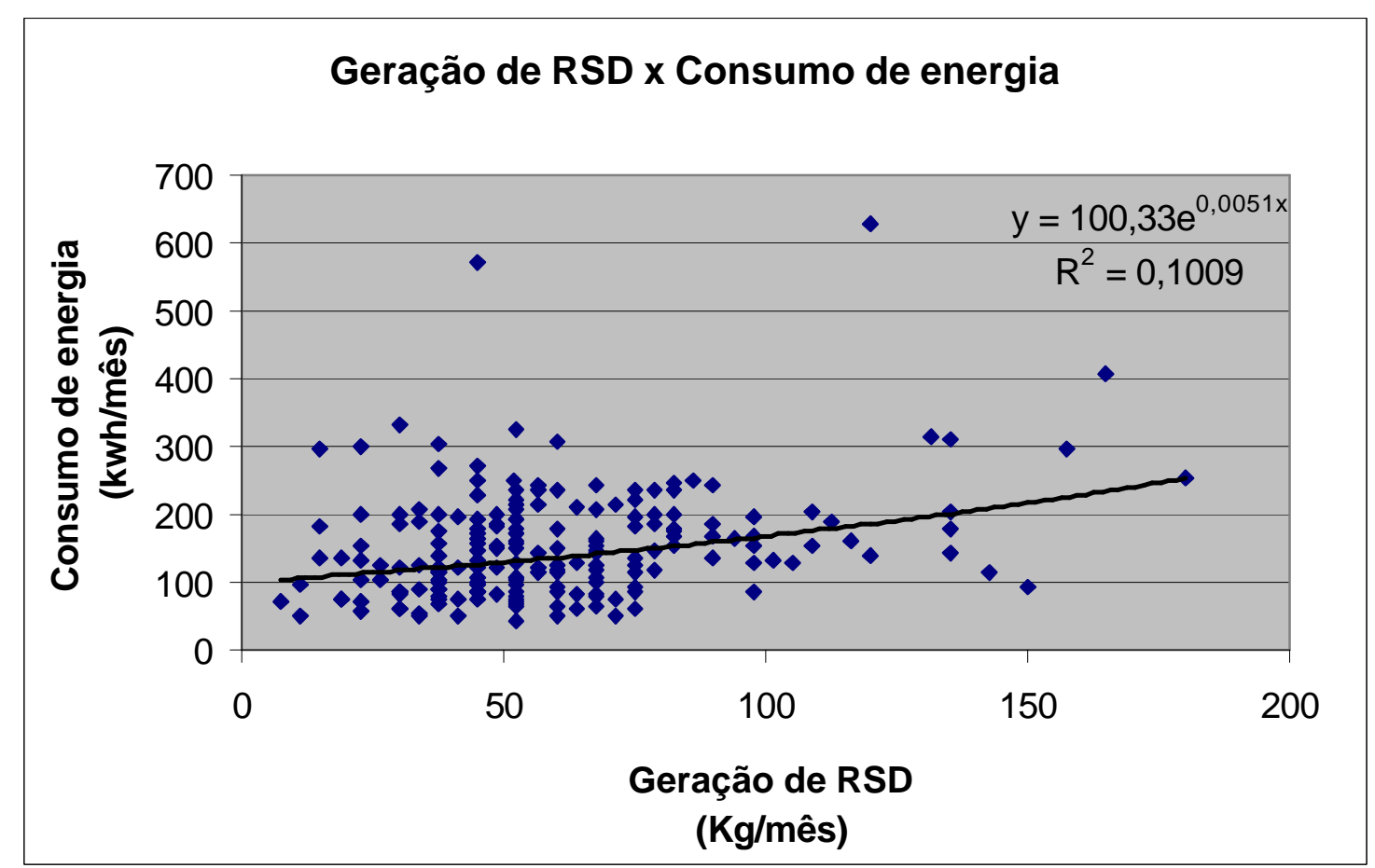

Figura 12 - Gráfico dos valores referentes ao consumo de energia x quantidade de RSD gerado

Comparando as várias opções de representação, a que melhor resultado apresentou foi a equação tipo exponencial, apresentando $\mathrm{R}^{2}=0,1$ (valor de pouca expressão). Buscando avaliar a contribuição da análise por faixas de consumo, onde cada faixa representaria uma categoria de consumidor, situado dentro de um grupo de consumidores com características de consumo próximas, dividiu-se então os grupos nas faixas apresentadas a seguir. 


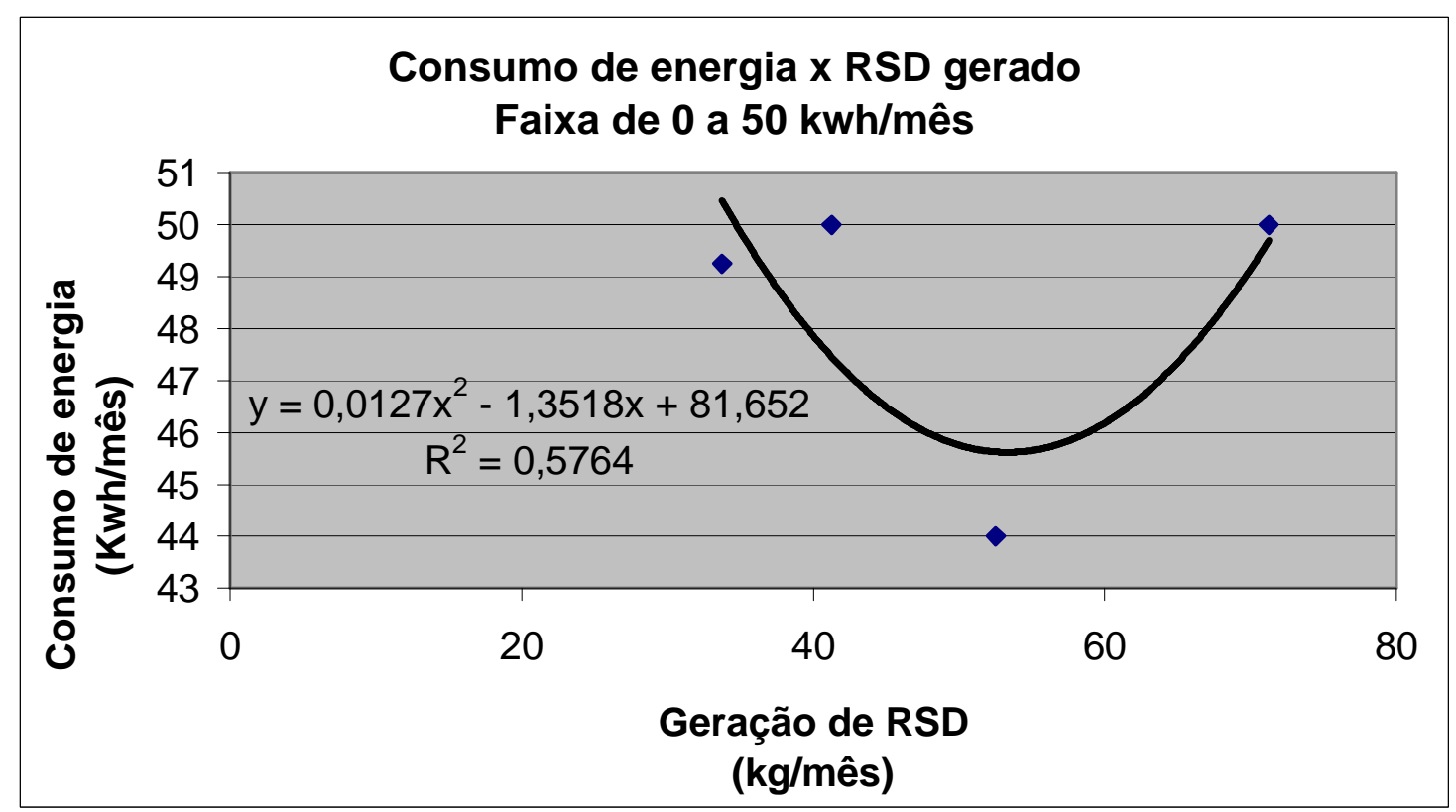

Figura 13 - Gráfico dos valores referentes ao consumo de energia elétrica x quantidade de RSD gerado para faixa de consumo de 0 a $50 \mathrm{kwh} / \mathrm{mês}$.

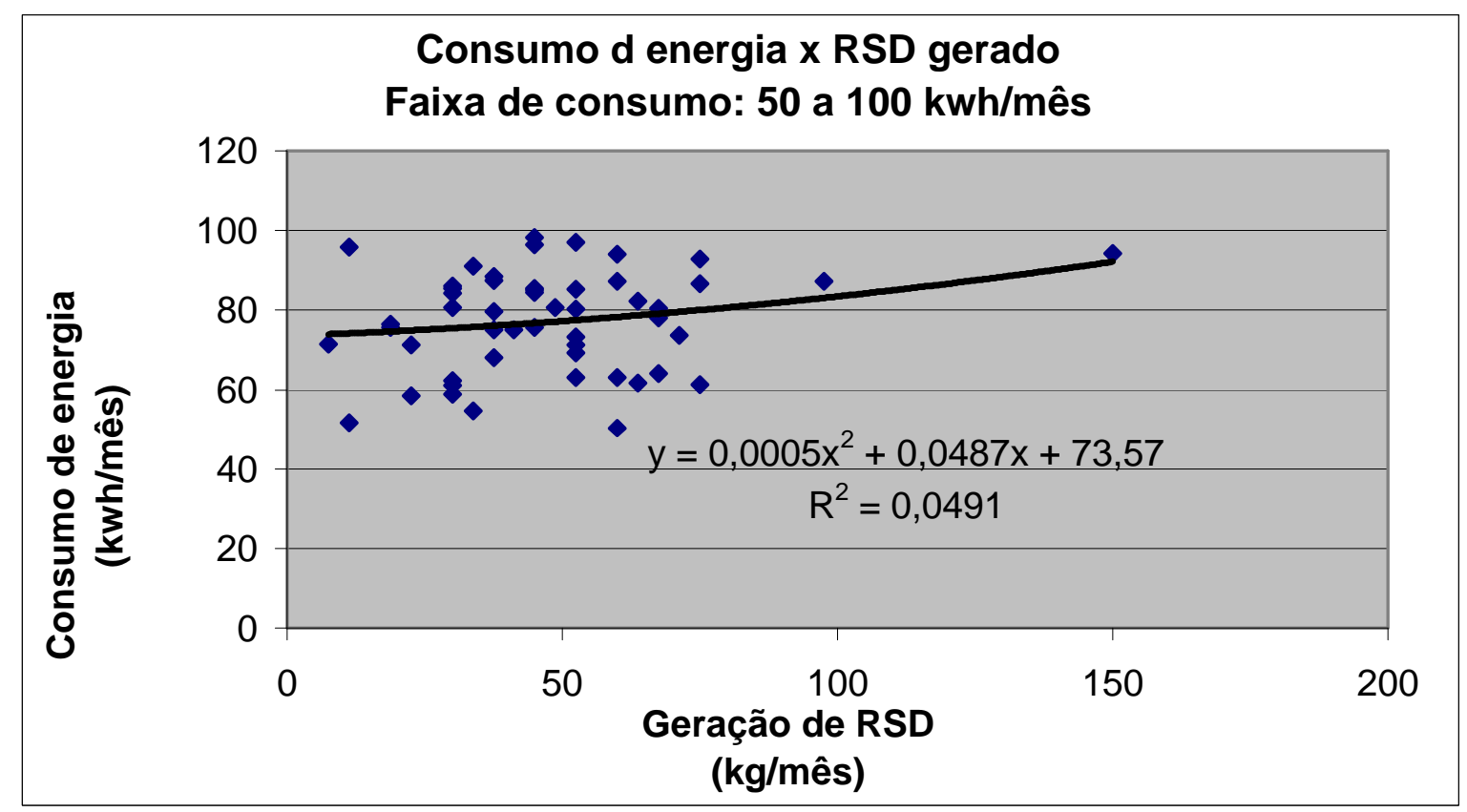

Figura 14 - Gráfico dos valores referentes ao consumo de energia elétrica x quantidade de RSD gerado para faixa de consumo de 50 a $100 \mathrm{kwh} / \mathrm{mês}$. 


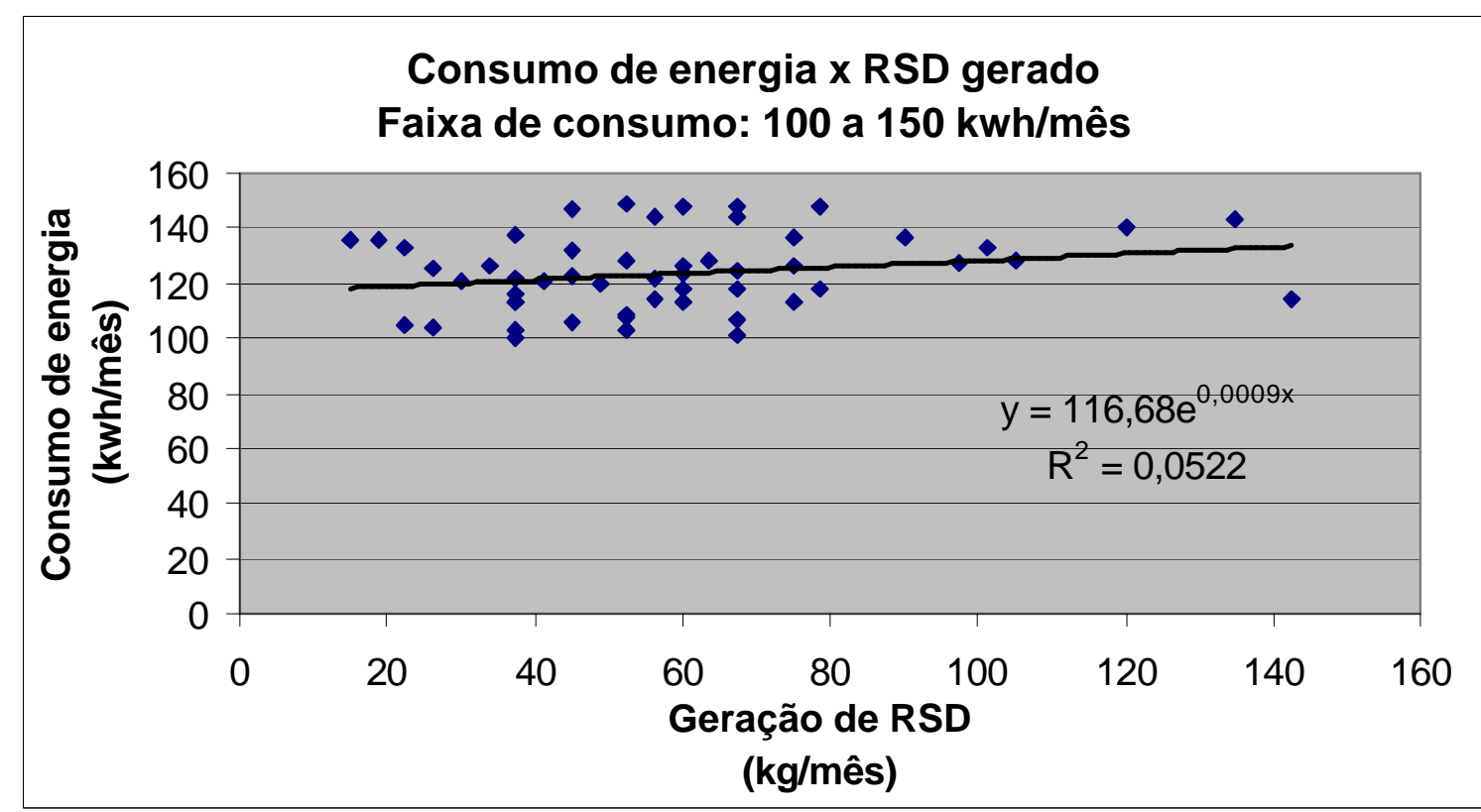

Figura 15 - Gráfico dos valores referentes ao consumo de energia elétrica x quantidade de RSD gerado para faixa de consumo de 100 a $150 \mathrm{kwh} / \mathrm{mês}$.

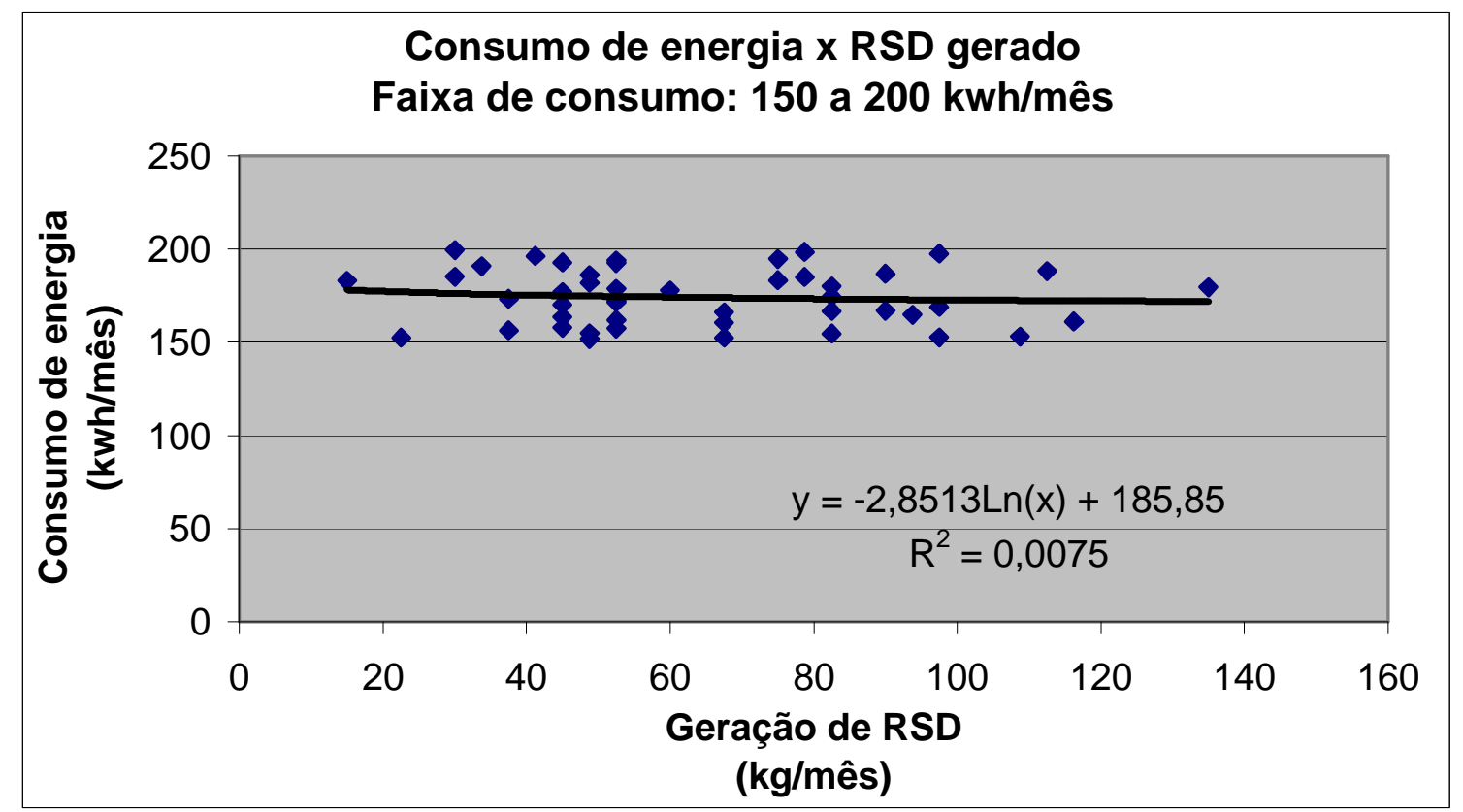

Figura 16 - Gráfico dos valores referentes ao consumo de energia elétrica $x$ quantidade de RSD gerado para faixa de consumo de 150 a $200 \mathrm{kwh} / \mathrm{mês}$. 


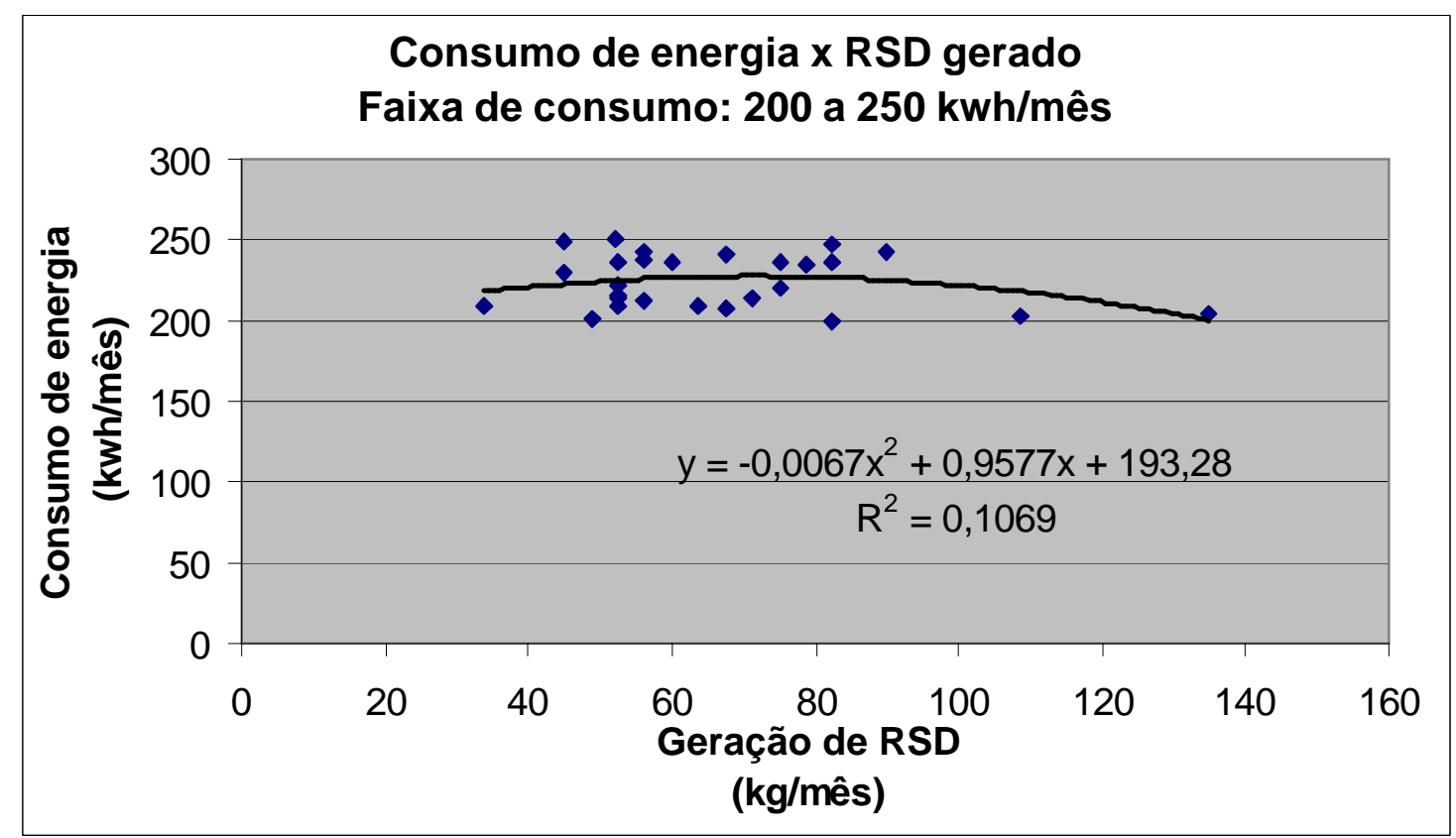

Figura 17 - Gráfico dos valores referentes ao consumo de energia elétrica x quantidade de RSD gerado para faixa de consumo de 200 a $250 \mathrm{kwh} / \mathrm{mês}$.

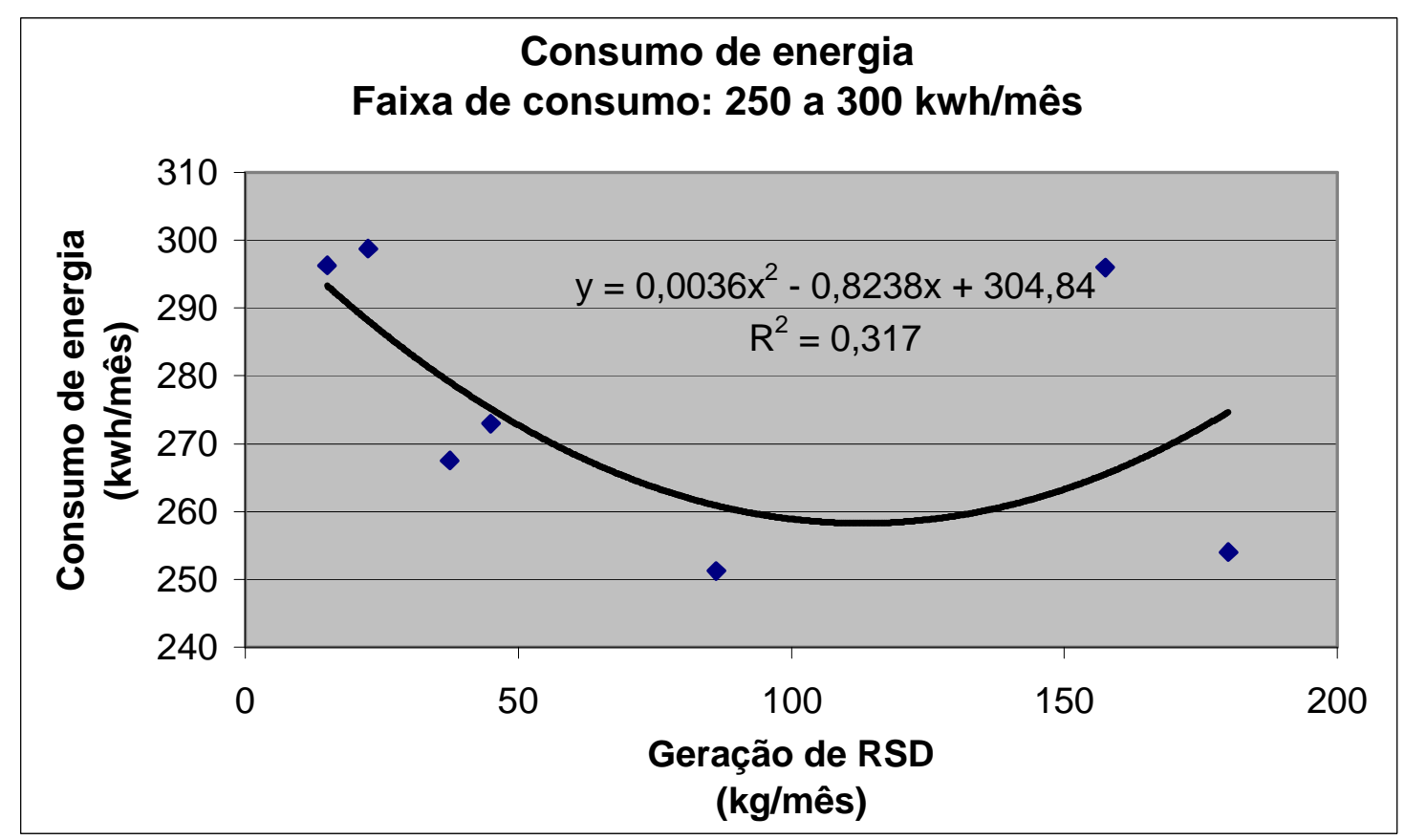

Figura 18 - Gráfico dos valores referentes ao consumo de energia elétrica $x$ quantidade de RSD gerado para faixa de consumo de 250 a 300 kwh/mês. 


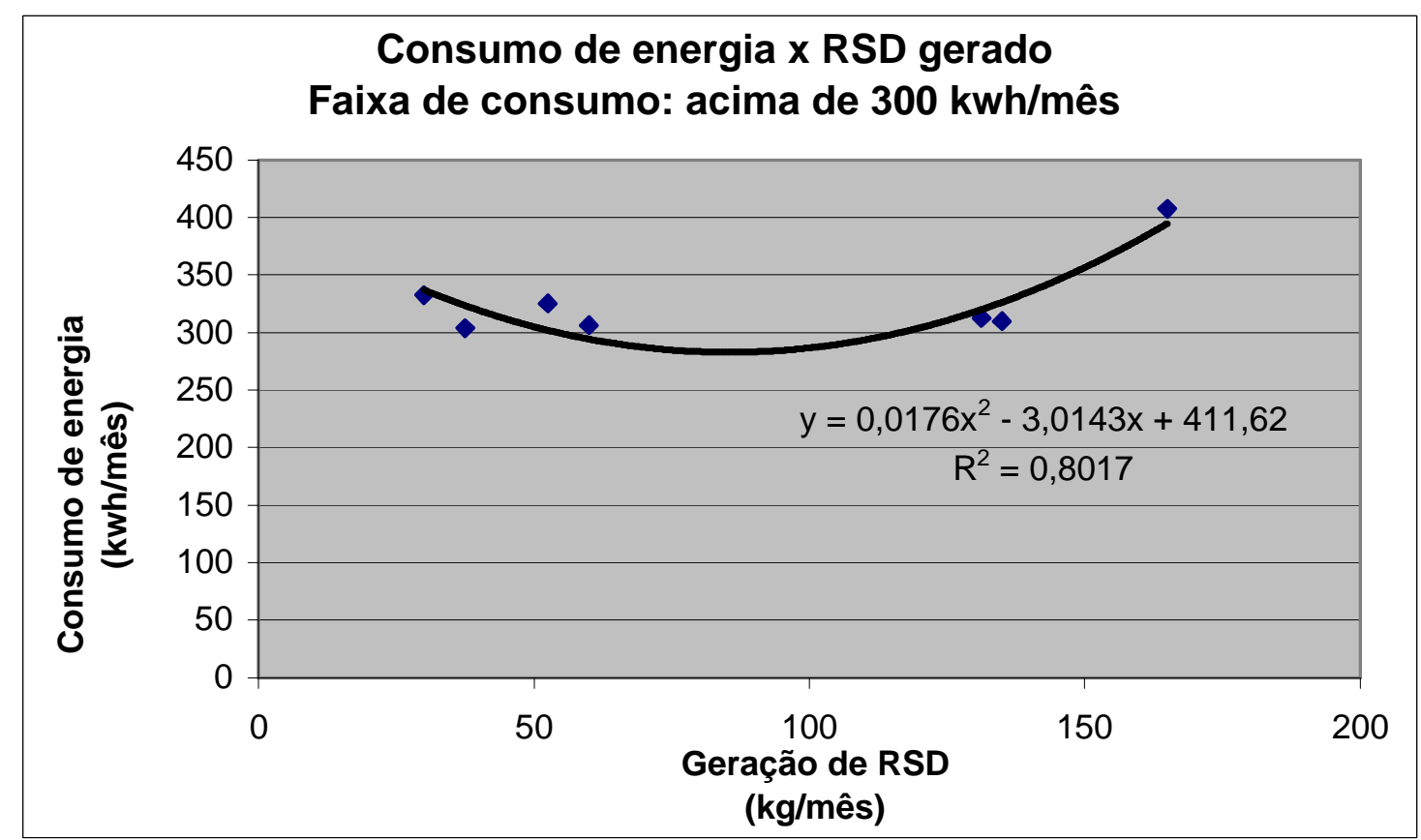

Figura 19 - Gráfico dos valores referentes ao consumo de energia elétrica x quantidade de RSD gerado para faixa de consumo acima de $300 \mathrm{kwh} / \mathrm{mês}$.

Novamente, buscando melhor representação da situação estudada, efetuou-se a análise dos dados de forma agrupada, pelo somatório dos consumos de energia elétrica para cada faixa, com o respectivo somatório da geração de RSD. A representação desta situação encontra-se na tabela 12 .

Tabela 12 - Valores obtidos por faixa de consumo de energia elétrica

\begin{tabular}{c|cc}
\hline Faixa de consumo & \multicolumn{2}{|c}{ Total por faixa } \\
\hline (Kwh/mês) & Energia Elétrica (kwh) & RSD (kg) \\
\hline 0 A 100 & 4135 & 2617,5 \\
100 A 200 & 14714,45 & 6142,5 \\
200 A 300 & 8392,25 & 2399,5 \\
300 A 400 & 1890 & 446,25 \\
Acima de 400 & 1607,5 & 330 \\
\hline
\end{tabular}




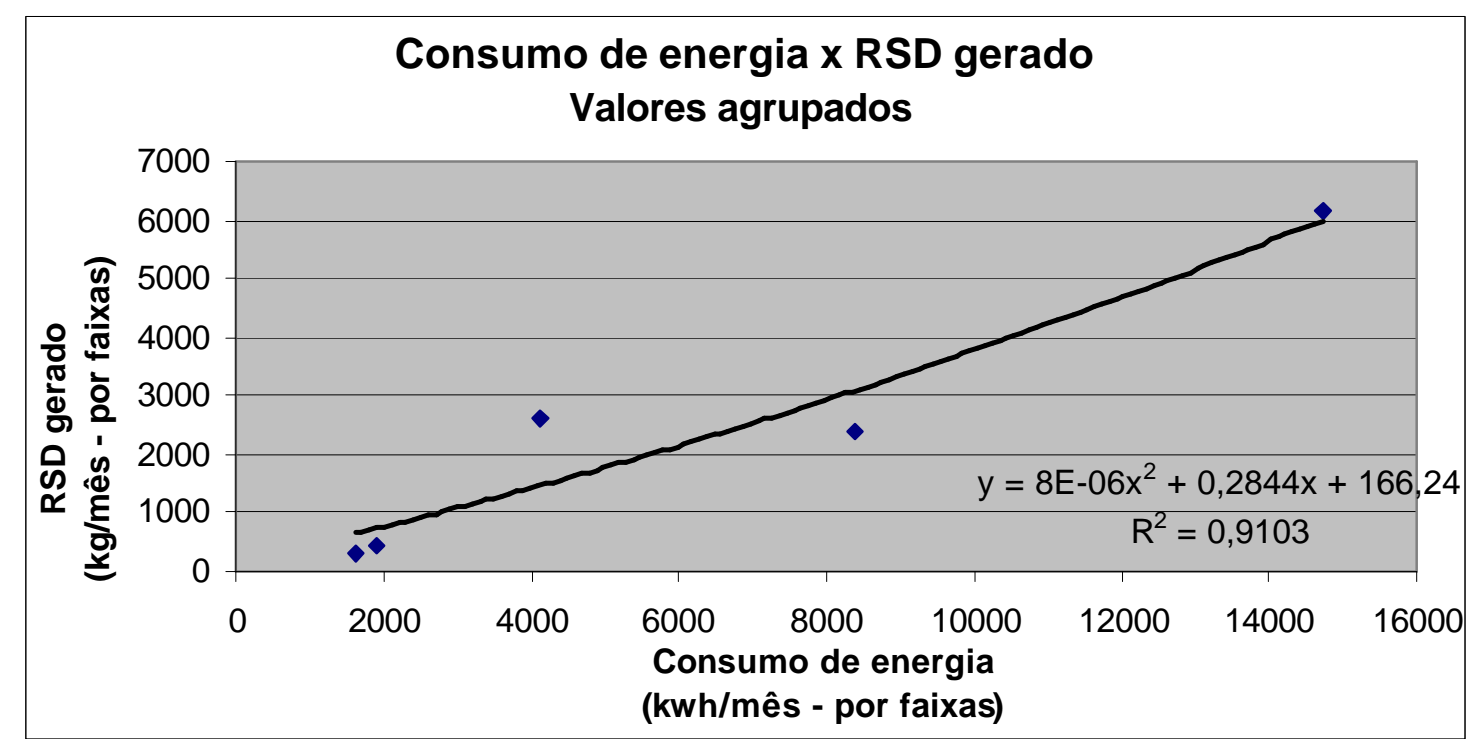

Figura 20 - Gráfico dos valores referentes ao consumo de energia elétrica x quantidade de RSD gerado para faixas de consumo agrupadas (conf. Tab. 12).

A situação encontrada permite supor que existe estreita relação entre a geração de RSD e a realidade do consumo de energia elétrica.

\subsubsection{Relação entre área construída e RSD gerado}

Completando a sequiência dos parâmetros analisados, seguem os resultados obtidos da análise da vinculação entre a área construída do imóvel e a geração de resíduos sólidos domiciliares - RSD's para a amostra de residências estudada. Para a visualização desta realidade, apresentam-se os gráficos originados a partir dos dados obtidos junto à população em questão. 


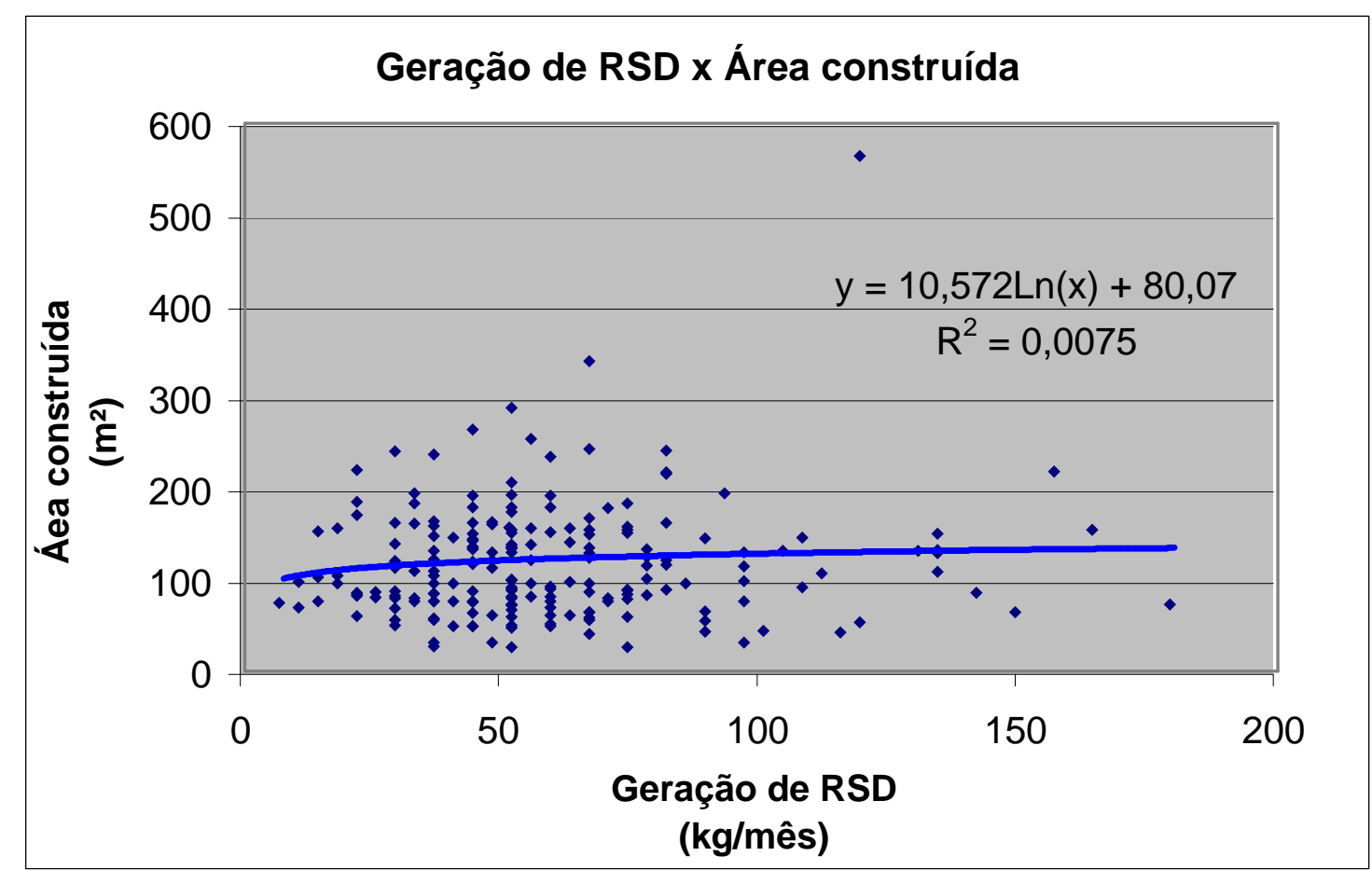

Figura 21 - Gráfico dos valores referentes à área construída x quantidade de RSD gerado

Neste caso, pode-se observar que dentre as três relações estudadas, esta apresentou o pior resultado, com erro muito grande $\left(\mathrm{R}^{2}=0,0075\right)$.

Objetivando avaliar a contribuição da divisão por faixas de tamanho da residência, seguem as representações obtidas para esta situação. 


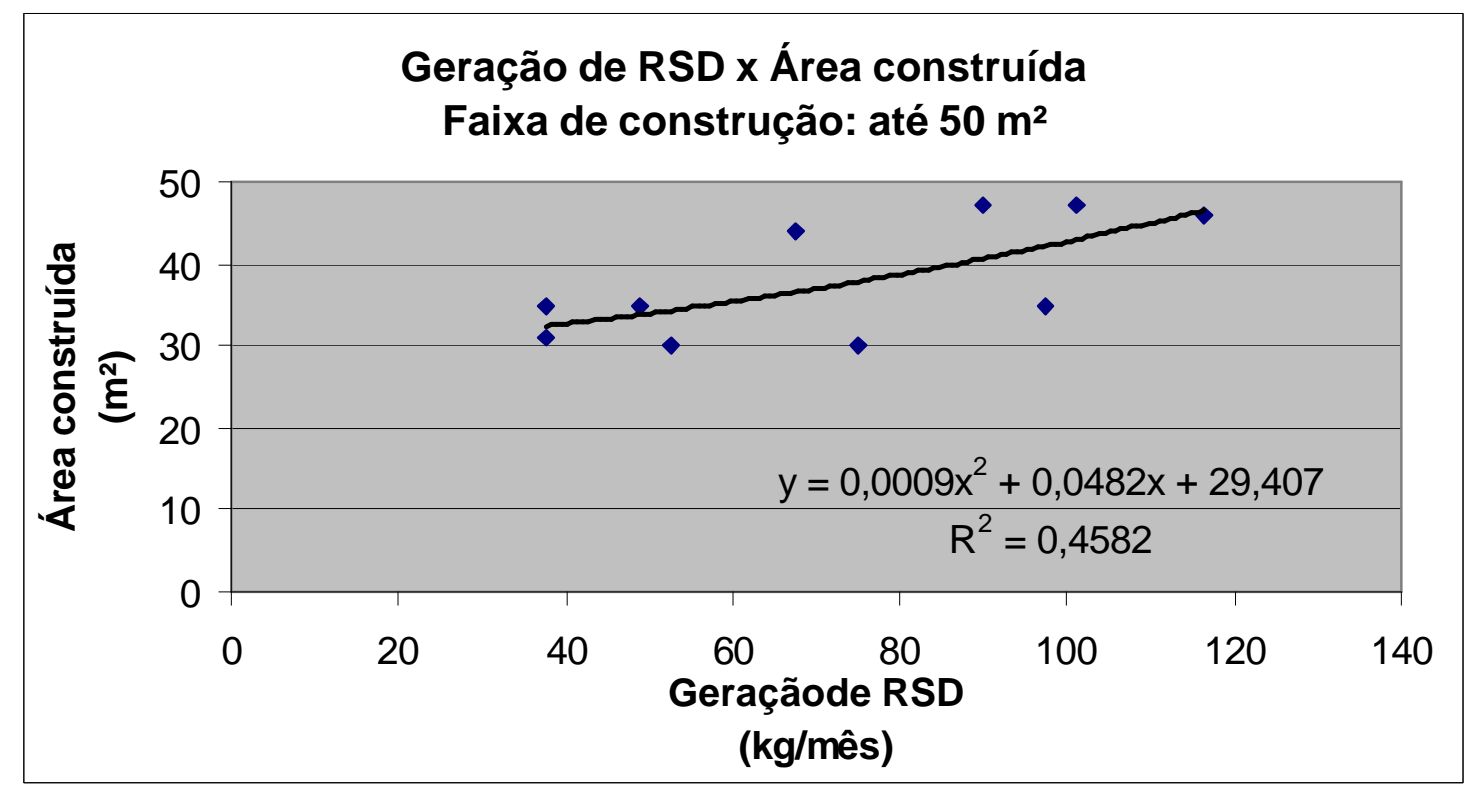

Figura 22 - Gráfico dos valores referentes à área construída x quantidade de RSD gerado para faixa de construção até $50 \mathrm{~m}^{2}$.

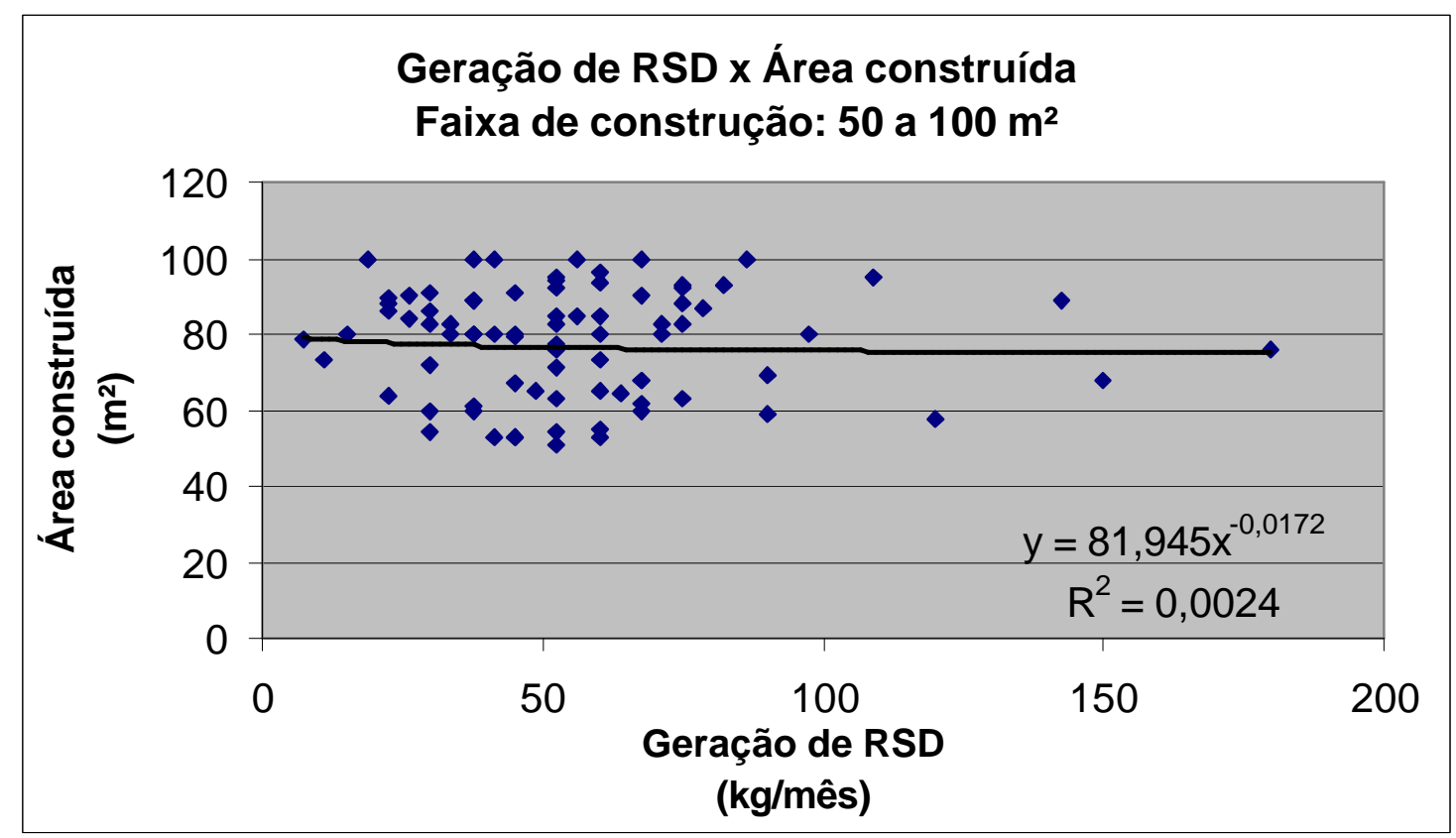

Figura 23 - Gráfico dos valores referentes à área construída x quantidade de RSD gerado para faixa de construção de 50 até $100 \mathrm{~m}^{2}$. 


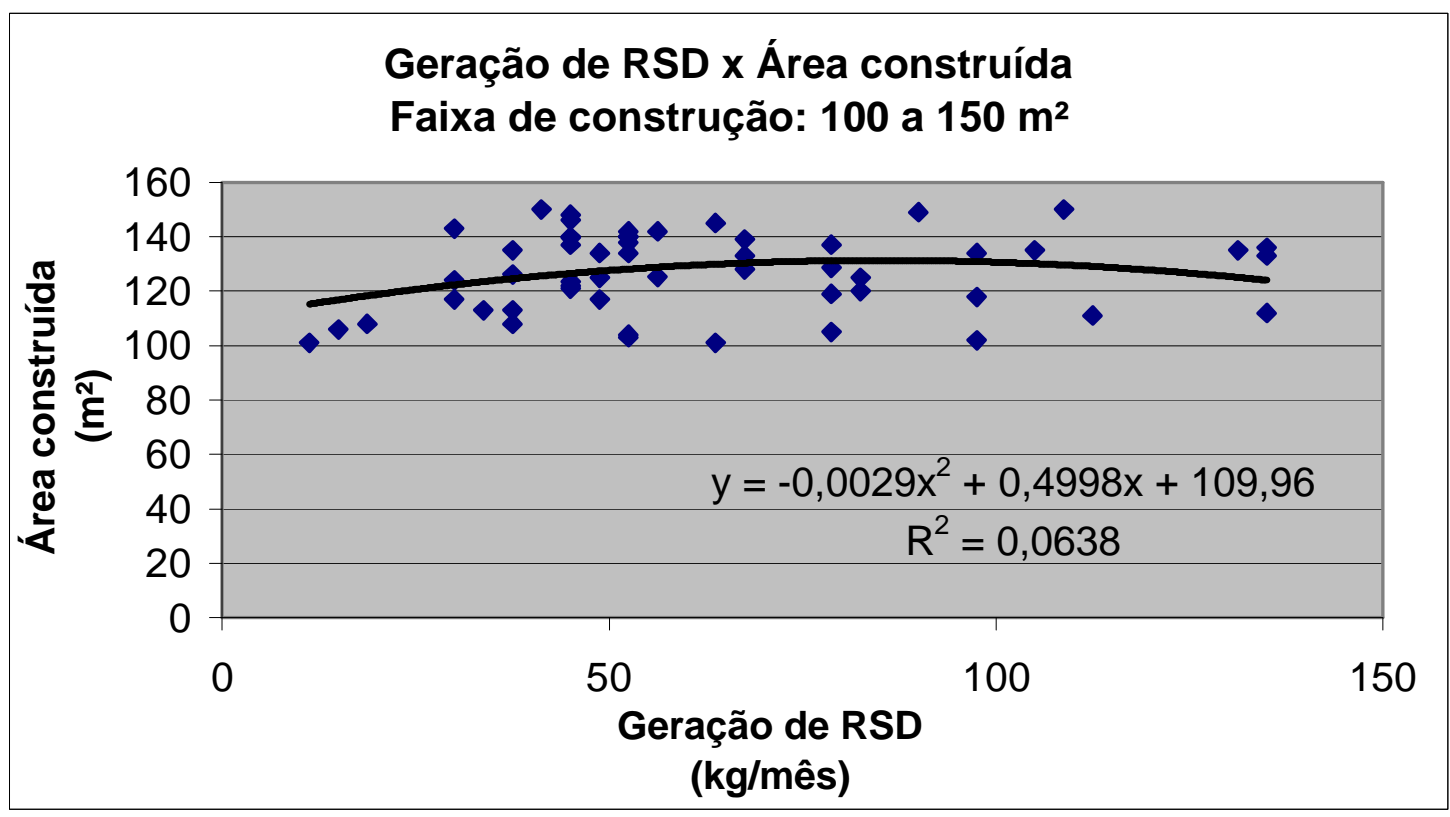

Figura 24 - Gráfico dos valores referentes à área construída x quantidade de RSD gerado para faixa de construção de 100 até $150 \mathrm{~m}^{2}$.

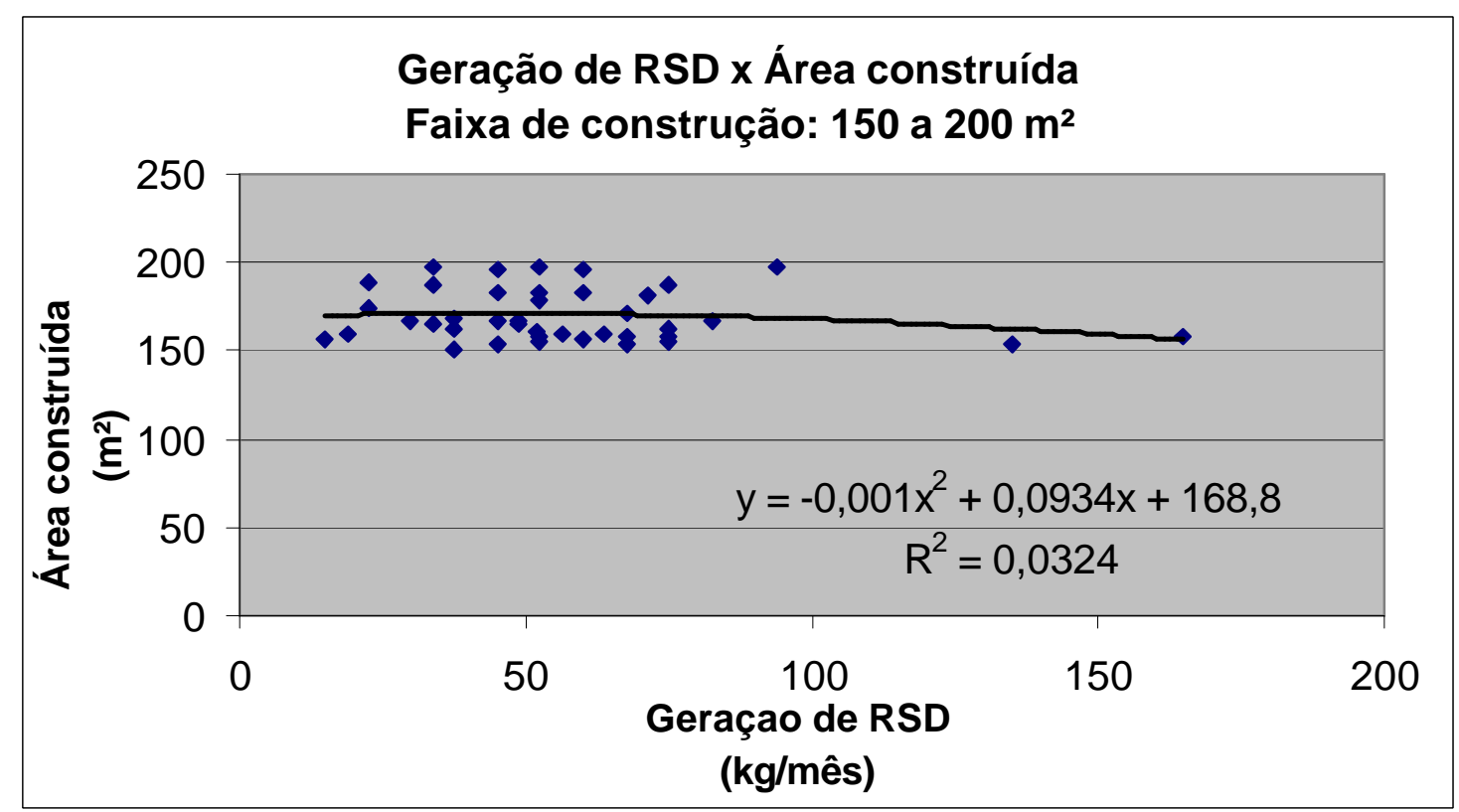

Figura 25 - Gráfico dos valores referentes á área construída x quantidade de RSD gerado para faixa de construção de 150 até $200 \mathrm{~m}^{2}$. 


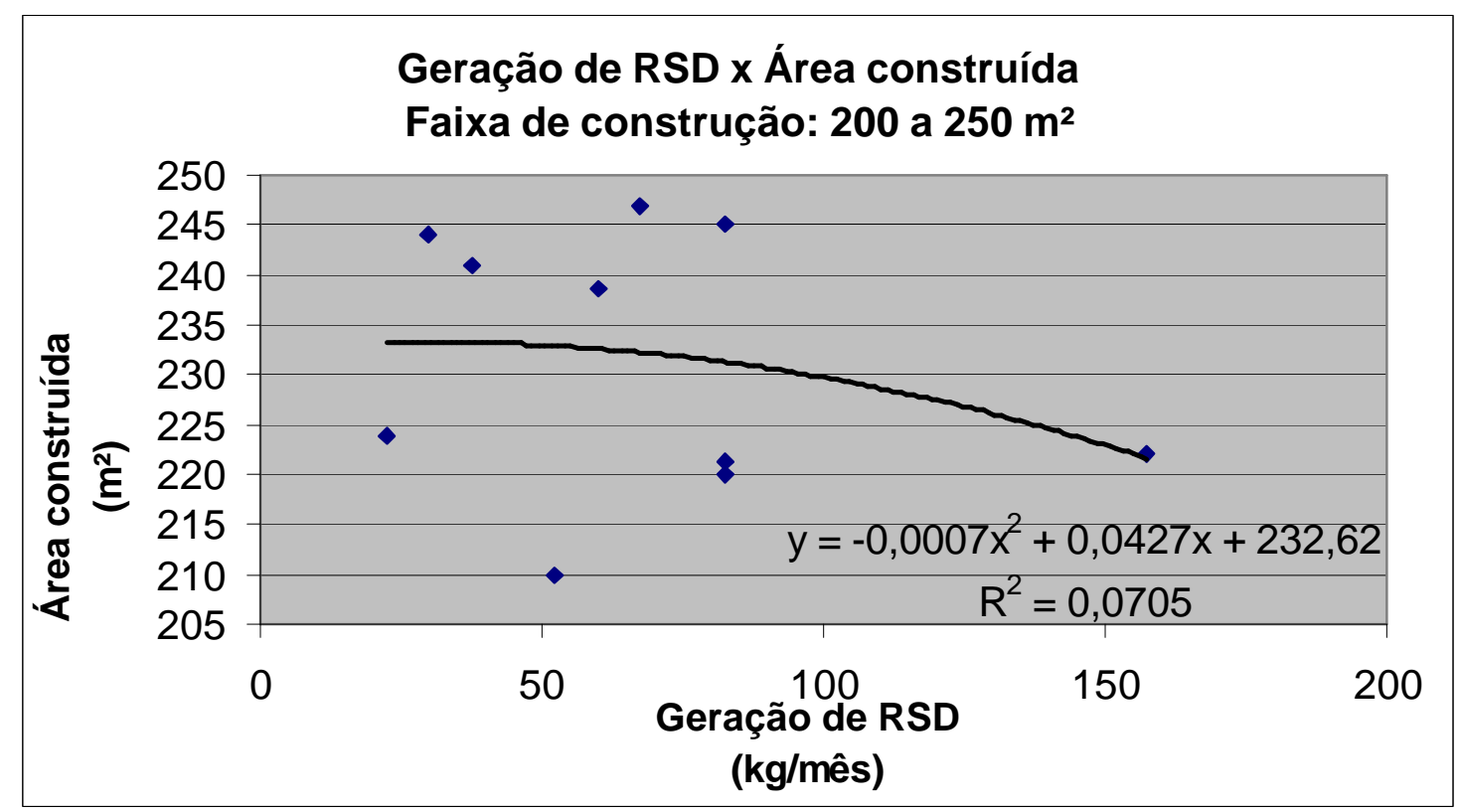

Figura 26 - Gráfico dos valores referentes à área construída x quantidade de RSD gerado para faixa de construção de 200 até $250 \mathrm{~m}^{2}$.

Finalmente, efetuou-se a análise dos dados relativos aos pares de valores área construída x RSD gerado, de forma agrupada, pelo somatório das áreas construídas para cada faixa, com o respectivo somatório da geração de RSD. A representação desta situação encontra-se na tabela 13.

Tabela 13 - Valores obtidos por faixa de consumo de energia elétrica

\begin{tabular}{c|cc}
\hline Faixa de consumo & \multicolumn{2}{|c}{ Total por faixa } \\
\hline $\left.\mathbf{( m}^{\mathbf{2}}\right)$ & Área construída $\left(\mathbf{m}^{\mathbf{2}}\right)$ & RSD $\mathbf{( k g})$ \\
\hline ATÉ 50 & 379,55 & 723,75 \\
50 A 100 & 6316,10 & 4530,00 \\
100 A 150 & 6860,77 & 3401,25 \\
150 A 200 & 6797,44 & 2264,50 \\
200 A 250 & 2312,90 & 675,00 \\
250 ACIMA & 1728,70 & 341,25 \\
\hline
\end{tabular}




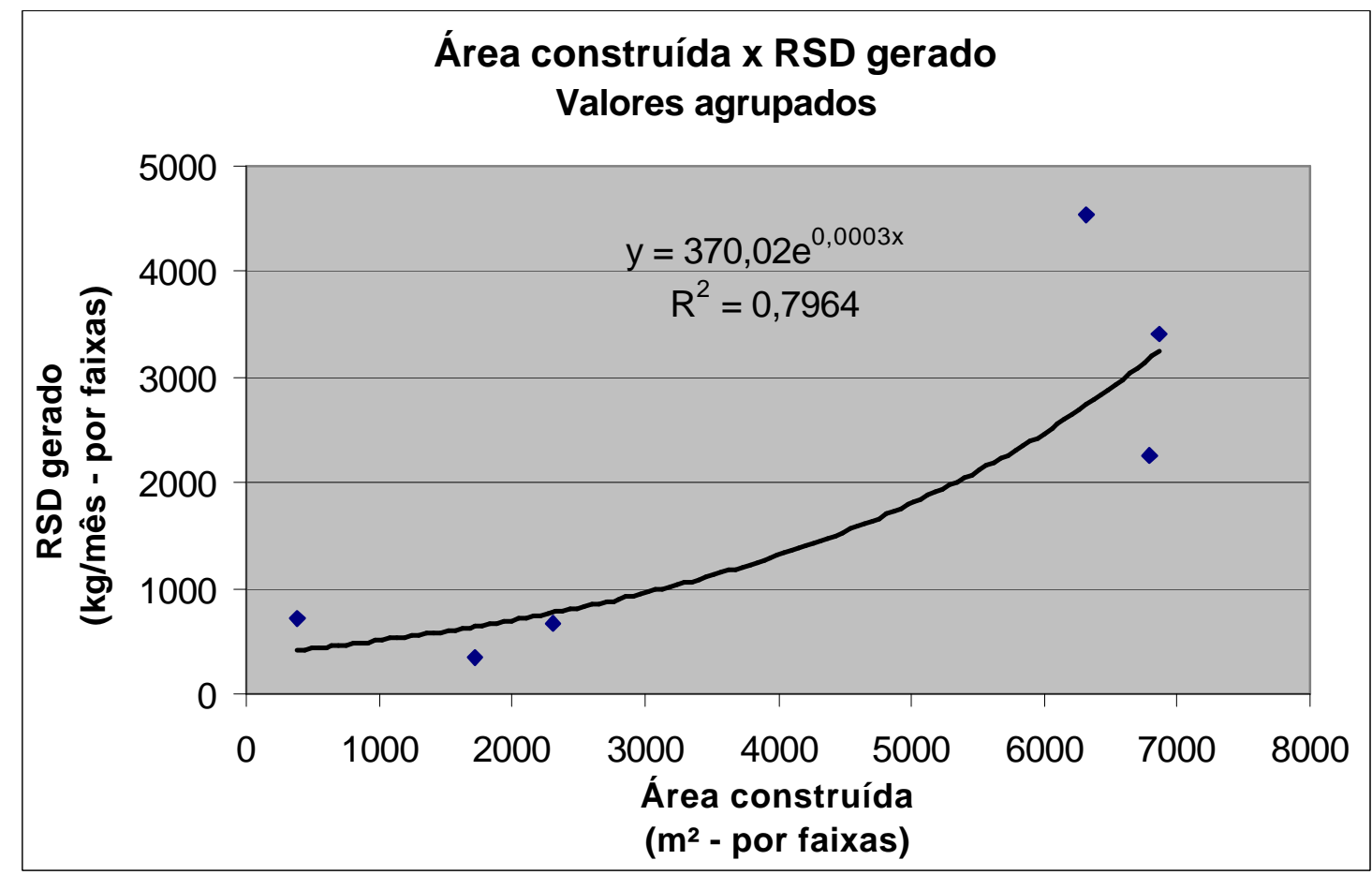

Figura 27 - Gráfico dos valores referentes à área construída x quantidade de RSD gerado para faixas de consumo agrupadas (conf. Tab. 13).

\subsubsection{Outras informações obtidas}

Como resultado secundário da pesquisa realizada, obteve-se um panorama da situação de ocupação do imóvel, através do total de pessoas por residência, dentro do universo da pesquisa.

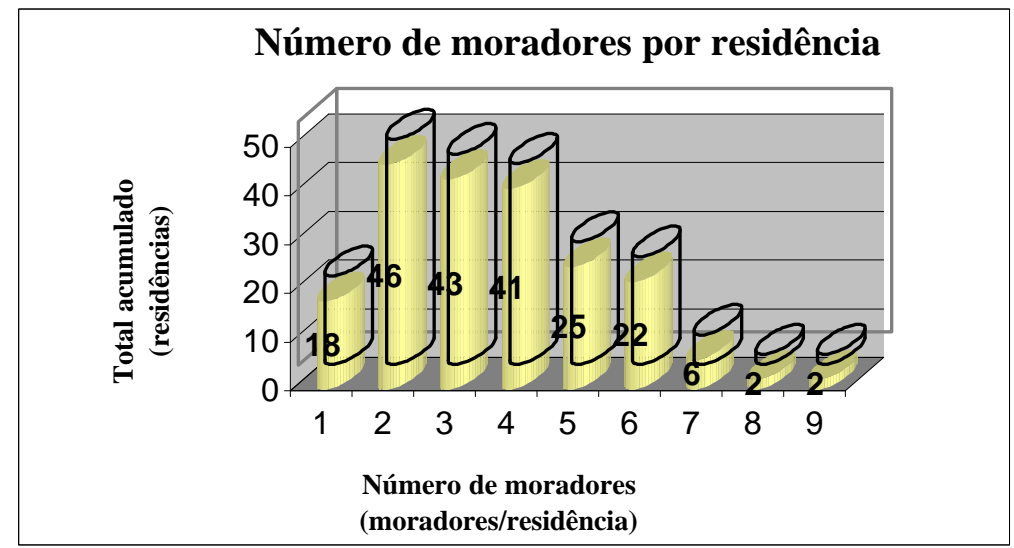

Figura 28 - Número de moradores por residência pesquisada, Taiaçu, 2005 


\subsection{Discussão}

Tendo verificado as combinações de parâmetros de consumo residencial com a geração dos resíduos sólidos domiciliares - rsd, pôde-se observar que a relação que melhor resultado apresentou foi a que vincula a geração de resíduos com o consumo de energia elétrica da residência $\left(\mathrm{r}^{2}=0,91\right)$. Também se verificou a estreita relação com o consumo de água da residência $\left(\mathrm{r}^{2}=0,89\right)$, apontando para a equivalência entre estes parâmetros (consumo de energia e consumo de água), quando os mesmos são estudados como indicadores (indiretos) da geração de rsd.

A forma de tratar os dados, de forma agrupada, mostrou-se apropriada na obtenção de equações que representam com a precisão aceitável, os valores referentes à geração de rsd por residência. Em virtude do tempo envolvido com o trabalho de coleta de dados e do grande número de residências a serem pesquisadas, não foi possível estender o tempo (em semanas) para a coleta dos pesos de resíduos gerados.

Ao se trabalhar com valores médios, transformando os dados obtidos em quantidades mensais, a pequena quantidade de informação permitiu a representação notada nas figuras 5, 12 e 21, onde se observa uma dispersão acentuada nos valores estudados.

Por fim, há que se observar que por mais que se procure atingir todos os fatores responsáveis pela geração de resíduos sólidos domiciliares (o alvo da pesquisa), existem situações particulares que impedem a vinculação de valores crescentes, ou seja, não há na realidade a garantia de que ao se aumentarem os consumos da residência, ter-se-á também o respectivo aumento na geração de resíduos. Isto se deve às divergências existentes junto à população estudada, o que certamente ocorrerá em qualquer município pesquisado. O nível de renda, grau de instrução, atividade profissional, hábitos de consumo, etc., afetarão significativamente os dados obtidos em pesquisa.

A habilidade do profissional aliada à experiência adquirida ao trabalhar com estas questões, permitirá que os acertos sejam maiores que os erros e desse modo os resultados obtidos contribuirão de forma mais efetiva para o resultado desejado. 


\section{CONCLUSÕES E RECOMENDACÕES}

\subsection{Considerações preliminares}

Segundo a Constituição da República do Brasil, cabe aos municípios (este elenco de competências encontra-se disperso nos dispositivos constitucionais vigentes, em especial, no Título III Da Organização do Estado, Capítulo IV Dos Municípios; Título VI Da Tributação e do Orçamento, Capítulo I Seção V Dos Impostos dos Municípios; Título VII Da Ordem Econômica e Financeira, Capítulo II Da Política Urbana; Título VIII Da Ordem Social, Capítulo VI Do Meio Ambiente):

- organizar e prestar, diretamente ou sob regime de concessão ou permissão, serviços públicos de interesse local, incluído o de transporte coletivo, de caráter essencial;

- manter programas de educação pré-escolar e de ensino fundamental, com a cooperação técnica e financeira da União e do Estado;

- aplicar não menos de vinco e cinco por cento da receita resultante de impostos, compreendidas as transferências, na manutenção e desenvolvimento do ensino;

- prestar serviços de atendimento à saúde da população residente, com a cooperação técnica e financeira da União e do Estado;

- promover ordenamento territorial, mediante planejamento e controle do uso, do parcelamento e da ocupação do solo urbano;

- executar a política de desenvolvimento urbano e ordenar o pleno desenvolvimento das funções sociais da cidade e garantir o bem-estar de seus habitantes;

- instituir o Plano Diretor, aprovado pela Câmara Municipal;

- promover a proteção do patrimônio histórico-cultural local, observada a legislação e a fiscalização federal e estadual;

- $\quad$ reger-se por Lei Orgânica; 
- promover a cooperação das associações representativas no planejamento municipal;

- instituir e arrecadar os tributos de sua competência e aplicar suas rendas, sendo impostos de sua exclusiva competência o incidente sobre propriedade predial e territorial urbana (IPTU), inclusive de caráter progressivo para assegurar o cumprimento da função social da propriedade;

- observar na aplicação de suas rendas e receitas a Lei de Diretrizes Orçamentárias - LDO, a Lei Orçamentária Anual e o Plano Plurianual de Investimentos, além da Lei Complementar $\mathrm{n}^{\circ}$. 101, de maio de 2000 (Lei de Responsabilidade Fiscal - LRF);

- constituir Guarda Municipal destinada à proteção de seus bens, serviços e instalações;

- preservar e restaurar os processos ecológicos essenciais e prover o manejo ecológico das espécies e ecossistemas;

- definir espaços territoriais e seus componentes a serem especialmente protegidos;

- exigir prévio estudo de impacto ambiental;

- promover a educação ambiental e a conscientização pública para a preservação do meio ambiente;

- proteger a fauna e a flora.

Diante deste quadro legal, verifica-se a grande responsabilidade que o poder executivo municipal assume diante da gestão da coisa pública, do bem comum. Estas atribuições requerem a execução de trabalho capacitado, segundo critérios técnicos e legais, cujo plano de execução seja elaborado adequadamente, orientando o desenvolvimento das atividades necessárias e favorecendo a sustentabilidade da gestão pública municipal.

O estudo e a criação de legislação que dê suporte às atividades desenvolvidas pela administração municipal, com relação à questão tributária, permitirá o equilíbrio econômico, necessário sob vários aspectos, bem como promoverá justiça social, na medida em que distribuirá entre os contribuintes, de forma equilibrada, os custos decorrentes dos serviços prestados à comunidade atendida. 


\subsection{Conclusões}

Diante dos resultados obtidos, viabilizados pelo variado número de parâmetros estudados e pelas formas de tratamento dos dados pesquisados, a hipótese inicial apresenta-se como viável de utilização, possibilitando seu uso quando da determinação da cota que cada residência deve assumir dos custos de coleta, transporte e destinação final dos rsd.

A prática desta vinculação, a da geração de resíduos com algum consumo da residência, é crescente em municípios brasileiros, tendo sido encontrada com frequiência na pesquisa bibliográfica realizada, mostrando que alguns administradores buscam adequar legalmente suas formas de cobrança.

A forma com que atualmente as administrações municipais promovem a cobrança pelos serviços prestados, na grande maioria dos municípios que a efetuam, ainda está contrariando as disposições legais pertinentes.

A busca de saídas para este problema está no desenvolvimento de estudos e pesquisas, adaptadas a cada realidade existente, onde soluções locais serão implantadas objetivando adequar legal e socialmente os critérios de rateio das despesas realizadas com os essenciais serviços de coleta, transporte e destinação final dos resíduos sólidos domiciliares.

\subsection{Recomendações para trabalhos futuros}

Considerando-se a necessidade crescente de adequação legal dos municípios, no que se refere à cobrança da taxa de coleta, o desenvolvimento de estudos e pesquisas que objetivem ajuste nas suas legislações tributárias certamente encontrará um campo vasto de trabalho. Outras hipóteses iniciais poderão ser verificadas, sempre buscando parâmetros que permitam melhor forma de definição da cota de cada residência, na divisão dos custos entre os beneficiados pelos serviços públicos.

No caso em questão, após a conclusão da coleta de dados e o início da elaboração de tabelas e gráficos, tornaram-se evidentes a necessidade de efetuar a pesagem dos 
resíduos por um período maior de tempo, como forma de obterem-se dados mais representativos, que certamente teriam reflexo na nuvem de pontos dispersos no gráfico avaliado.

A proposta de utilização dos resultados do presente trabalho compreende o uso da equação obtida com o gráfico apresentado na figura 20 (pág. 71), ou seja:

$$
y=8 E-06 x^{2}+0,2844 x+166,24
$$

onde:

- a coordenada $\mathbf{y}$ representa a quantidade de resíduos sólidos domiciliares gerados na residência, em valor acumulado por faixa de geração ( $\mathrm{kg} / \mathrm{mês} /$ faixa);

- A coordenada $\underline{\mathbf{x}}$ representa o consumo de energia elétrica da residência no mês, em valor acumulado por faixa de consumo de energia (kwh/mês/faixa).

Calculando-se o valor de $\mathbf{y}$ para cada residência, estes valores seriam somados, obtendose o total destes valores. A parcela de cada residência seria então obtida pela divisão de seu valor unitário por este montante, gerando assim o peso daquele contribuinte.

Tendo-se o valor total das despesas anuais com os serviços de coleta, transporte e destinação final dos resíduos domiciliares, se determinaria então o valor a ser cobrado de cada residência, pela multiplicação do peso unitário pelo total apurado das despesas. 


\section{REFERÊNCIAS BIBLIOGRÁFICAS}

ANDRADE, J. B. L. Avaliação do sistema de limpeza urbana na cidade de Campina Grande. Campina Grande, 1989. 280 p. Dissertação (Mestrado) - Universidade Federal da Paraíba, Engenharia Civil.

ASSOCIAÇÃO BRASILEIRA DE NORMAS TÉCNICAS. Resíduos sólidos: classificação, NBR 10004, NBR 10005, NBR 10006, NBR 10007. Rio de Janeiro, 2004.

ASTIER, M.; MASERA, O. Metodología para a evaluación de sistemas de manejo de recursos naturales incorporando indicadores de sustentabilidade. n. 17, abril 1996. 26 p.

BAUER, S.; MIRANDA, M. L. (1996). The urban performance of unit pricing: an analysis of variable rates for residential garbage collection in urban areas. School of the Environment, Duke University.

BEZERRA, M. C. L.; FERNANDES, M. A.. Cidades Sustentáveis: subsídio á elaboração da Agenda 21 brasileira 2000 : Brasília, 2000. Disponível na Internet <http://www.mma.gov.br/port/se/agen21/ag21bra/ doctematicos.html>.

BLANCHET, L. A. Concessão de serviços públicos. 2.ed. São Paulo: Juruá, 1999.

BONATO, C.. Curso de gerenciamento de resíduos sólidos. Porto Alegre: Ed. Da Assembléia Legislativa do Rio Grande do Sul, 1995.

BRANCO, Samuel Murgel. O meio ambiente em debate. 30.ed. São Paulo: Moderna, 1999. 
BRASIL. Constituição, 1988 (2002). Constituição da República Federativa do Brasil, 1998. Brasília, Senado federal - Prodasen. Disponível em: http://www.senado.gov.br/bdtextual/const88/const88.htm. Acesso em: 01 maio 2004. Última atualização: jan. 2002.

BRASIL. Código Tributário Nacional. São Paulo: Saraiva, 2000.

BRITO, K. G. Q. de; PEREIRA NETO, J. T.; CEBAllos, B. S. O. de. Bom gerenciamento do lixo urbano melhora a qualidade de vida e aumenta o sentimento de cidadania. In: SEMINÁRIO NACIONAL SOBRE RESÍDUOS SÓLIDOS (4. : 2000 : Recife). Anais. Recife: ABES PE/PB/DN, 2000. p. 215-219.

BRUNDTLAND, G. H. Nosso futuro comum. 2.ed. Rio de Janeiro: FGV, 1991.

BURGIEL J.; RANDALL R. (1998). National unit-based pricing survey results. New York: Solid Waste Association of North America and R. W. Beck, Inc.

CALDERONI, S.. Os bilhões perdidos no lixo. 2.ed. São Paulo: Humanistas, 1998.

CAMPINAS (cidade). Lei Municipal nº 6.355, de 26 de dezembro de 1990. Estabelece o Código Tributário do município de Campinas-SP. Disponível em : http://.campinas.sp.gov.br/financas/dri/leis/ctm.html. Acesso em 15 jan. 2004.

CASSONE, Vittorio. Direito tributário: fundamentos constitucionais, análise dos impostos, incentivos à exportação, doutrina, prática e jurisprudência. 11.ed. São Paulo: Atlas, 1999.

CEMPRE: compromisso empresarial para reciclagem. Curitiba: SEBRAE-PR, 2001. (apostila).

CETESB. Coleta seletiva de lixo doméstico no Bairro Agostino, município de São Miguel D’Oeste/SC, objetivando a reciclagem. Disponível na Internet: <http://www.jcbrasil.org.br/cajusmo/projetoandorinha.htm>. 
CRUZ, M.C.M.T., org. (2001). Consórcios Intermunicipais: uma alternativa de integração regional ascendente. Programa Gestão Pública e Cidadania/EAESP/FGV. São Paulo, Polis. 96 p. Disponível em: http://www.polis.org.br/publicacoes/download/arquivos/cadbid5.pdf. Acesso em: 06 abr. 2004.

D’ELIA, D.M.C., (2000). Relação entre utilização de água e geração de resíduos sólidos domiciliares. Revista Saneamento Ambiental, São Paulo, nº 65, p.38-41, mai.

FELLEMBERG, G. Introdução aos problemas de poluição ambiental. São Paulo: EDUSP, 1977.

FIGUEIREDO, P.J.M. A sociedade do lixo: os resíduos, a questão energética e a crise ambiental. Piracicaba: Ed. UNIMEP, 1995.

FLORIANÓPOLIS (cidade). Lei Municipal n 3.499, de 12 de dezembro de 1990. Altera o Código Tributário Municipal de Florianópolis-SC. Disponível em: http://www.leismunicipais.com.br/sc/florianopolis/. Acesso em 16 jan. 2004.

FONSECA, E. Iniciação ao estudo dos resíduos sólidos e da limpeza urbana. João Pessoa: Ed. União, 1999.

GIL, A. C. Métodos e técnicas de pesquisa social. São Paulo: Atlas, 1994.

GIL, A. C. Técnicas de pesquisa economia. São Paulo: Atlas, 1995.

GRIPP, W.G. Gerenciamento de resíduos sólidos municipais e os sistemas complexos: a busca da sustentabilidade e a proposta de cobrança da coleta em Santo André-SP. Tese (Doutorado)- Escola de Engenharia de São Carlos-Universidade de São Paulo, 2004. 
GÜTHS, L. D. Do mapeamento geo-ambiental ao planejamento urbano de Marechal Cândido Rondon. Florianópolis, 1999. Dissertação (Mestrado) - Universidade Federal de Santa Catarina.

IBGE - INSTITUTO BRASILEIRO DE GEOGRAFIA E ESTATÍSTICA (2002). Pesquisa nacional de saneamento básico 2000 - PNSB 2000. CD-Room. Rio de Janeiro: IBGE.

IDEC, Artigo Técnico (idec $6 \quad$ lixo) $\quad$ - disponível em http://www.idec.org.br/biblioteca/mcs lixo.pdf

IETEC. Disponível na Internet<www.ietec.com.br>.

KIEHL, E. J. Fertilizantes orgânicos. São Paulo: Agronômica Ceres, 1985.

LEITE, W. C. de A. (1997). Estudo da gestão de resíduos sólidos: uma proposta de modelo tomando a unidade de gerenciamento de recursos hídricos (UGRHI-5) como referência. São Carlos. Tese de Doutorado - Escola de Engenharia de São Carlos, Universidade de São Paulo.

LIMA et al. Educação ambiental a distância: classificação do lixo. Disponível na Internet: < http://www2.uel.br/pos/quimica/lixourbano/pag>. 1999.

LIMA, V. R. de; SOUSA, I. C. de; TÁVORA, U. Problemas ambientais. Disponível na Internet: < http://www.br500.futuro.usp.br>.

LERIPIO, A. A. Gestão da qualidade ambiental. Florianópolis, 1999. Dissertação (Mestrado em Engenharia de Produção) - Universidade Federal de Santa Catarina.

LIMA, L. M. Q. Tratamento de lixo. 2.ed São Paulo: Hemus, 1991.

MACHADO, H. B. Curso de direito tributário. 17.ed. São Paulo: Malheiros Editores, 2000. 
MALHADAS, Z. Z. Dupla ação: conscientizAção e educAção ambiental para a sustentabilidade : a Agenda 21 vai à escola. Curitiba: NIMAD, 2001.

Manual de Gerenciamento Integrado de resíduos sólidos / José Henrique Penido Monteiro ...[et al.]; coordenação técnica Victor Zular Zveibil. Rio de Janeiro: IBAM, 2001.

MARCONI, M. de A.; LAKATOS, E. M. Técnicas de pesquisa: técnicas e execução de pesquisas, amostragens e técnicas de pesquisa, elaboração, análise e interpretação de dados. 3.ed. São Paulo: Atlas, 1996.

MELLO, C. A. B. Curso de direito administrativo. 5.ed. São Paulo: Malheiros, 1994.

MIRANDA, M. L.; BAUER, S. D.; ALDY J. E. (1995). Unit pricing programs for residential solid waste: an assessment of the literature. School of the Environment, Duke University.

MIRANDA, M. L.; La PALME, S. (1997). Unit pricing of residential solid waste: a preliminary analysis of 212 U.S. communities. School of the Environment, Duke University.

MOTTA, R. S. da; SAYAGO, D. E. Propostas de instrumentos econômicos ambientais para a redução do lixo urbano e o reaproveitamento de sucatas no Brasil. Rio de Janeiro: IPEA, 1998

MUNHOZ, Tânia. Desenvolvimento sustentável e educação ambiental. Disponível na Internet <http://www.intelecto.net/cidadania/meio-5.html>. Acesso em 16 set. 2002.

NARUO, MAURO KENJI. O estudo do consórcio entre municípios de pequeno porte para disposição final de resíduos sólidos urbanos utilizando sistema de informações geográficas. Tese de mestrado - Escola de Engenharia de São Carlos, Universidade de São Paulo, 2003. 
OBLADEN, N.L.; TOKUDOME, M.; WESTPHAL, S. Coleta seletiva e reciclagem de resíduos sólidos urbanos. In: SEMINÁRIO INTERNACIONAL SOBRE COLETA SELETIVA E RECICLAGEM OU RESÍDUOS SÓLIDOS URBANOS (21-24 junho : 1995). Anais. Marechal Cândido Rondon: Prefeitura Municipal, 1995. p. 22-62.

PENIDO, J. H. In: SIMPÓSIO INTERNACIONAL DE DESTINAÇÃO DO LIXO (2. : 1997 : Salvador). Anais... Salvador, 1997.

REA, L. M.; PARKER, R. A. Metodologia de pesquisa: do planejamento à execução. São Paulo: Pioneira, 2000.

SCHALCH, V.; LEITE, W. C. A. (1998). Resíduos sólidos (lixo) e meio ambiente. In: CASTELlANO, E. G. (ed.) Desenvolvimento sustentado: problemas e estratégias. São Paulo: Academia de Ciências do Estado de São Paulo.

SCHALCH, V. (1995). Gerenciamento integrado de resíduos sólidos. In: Curso sobre gerenciamento integrado de resíduos sólidos. Fortaleza: ABES - UFC.

SCHALCH, V. et al. (1995). Gerenciamento integrado de resíduos sólidos. In: Simpósio Ítalo-Brasileiro de Engenharia Sanitária e Ambiental, 2., Paduva, 1995. Anais: Pollution in large cities. Paduva: ABES - ANDIS.

SCHALCH, V.; LEITE, W. C. A. (1998). Resíduos sólidos (lixo) e meio ambiente. In: CASTELLANO, E. G. (ed.) Desenvolvimento sustentado: problemas e estratégias. São Paulo: Academia de Ciências do Estado de São Paulo.

SILVA, E. L. da; MENEZES, E. M. Metodologia da pesquisa e elaboração de dissertação. 2.ed. Florianópolis: Laboratório de Ensino a Distância da UFSC, 2001.

SPET, G. (1999). Financial concepts for solid waste management. In: Thematic Workshop 1 - Solid Waste Management \& Energy, Vienna, 8 e 9/11/1999. 
TAVARES, C.R.G.; BARROS JUNIOR, C. A situação do resíduo sólido urbano da cidade de Maringá. In: SEMINÁRIO NACIONAL SOBRE RESÍDUOS SÓLIDOS (4. : 2000 : Recife). Anais... Recife: ABES, 2000. p. 203-206.

TÁVORA JUNIOR, J.L.; LUCENA, L.F.L. Destino de resíduos sólidos urbanos: instrumentos econômicos para a escolha das alternativas. In: SEMINÁRIO NACIONAL SOBRE RESÍDUOS SÓLIDOS (4. : 2000: Recife). Anais... Recife: ABES, 2000. p. 454-457.

TCHOBANOGLOUS, G et al. (1993). Integrated solid waste management: engineering principles and management issues. EUA: McGraw-Hill.

UNIVERSIDADE SÃO JUDAS TADEU. V Simpósio Multidisciplinar. Disponível na Internet: 〈http://www.atibaia.com.br/sucata/index.htm>.

VAZ, J. C.; CABRAL, C. C. Coleta seletiva e reciclagem do lixo. Disponível na Internet: < http://www.federativo.bndes.gov.br/dicas/D001.htm>.

VIEZZER, M. L; OVALLES, O. Manual latino-americano de educação ambiental. São Paulo: GAIA, 1995.

VISTA ALEGRE DO ALTO (cidade). Lei Complementar Municipal nº 035, de 03 de novembro de 2.003. Dispõe sobre o Sistema Tributário do Município de Vista Alegre do Alto-SP. e dá outras providências. Obtida por solicitação ao endereço pmva@vistaalegredoalto.sp.gov.br em 15 de jan. 2004.

ZULAUF, W. (2001). Estruturas dos municípios para a criação e implementação do Sistema de Gestão Ambiental.. In: FORATTINI, G.D. A contribuição do IBAMA para a questão ambiental municipal. Disponível em: http://www.ecoambientalcom.br/gestaoambiental-municipio.htm. Acesso em 20 ago. 2004. 
APÊNDICE 


\section{Planilhas com dados da pesquisa}

Seqüência Consumo de energia Resíduos sólidos (residência) elétrica gerados

$$
\text { (Kwh/mês - médio) (kg/mês - média) }
$$
236,75

98,25

101

84,25

192,75

200

236

303,75

126,75

80,75

146,75

152,5

162

118

100,25

156,25

241,25

190,75

85,5

267,5

123,5

63

178,75

177

177,75

173,25

200,5

166,75

171,5

179,5

122,75

87,25

50,25

126,75

247,75

85,25

209,25

71,25
52,5

45

67,5

30

45

37,5

60

37,5

75

30

45

67,5

52,5

60

37,5

37,5

67,5

33,75

30

37,5

60

60

52,5

45

60

37,5

48,75

82,5

52,5

135

45

60

60

33,75

82,5

52,5

63,75

52,5
Área construída Consumo de água do imóvel do imóvel $\left(\mathrm{m}^{2}\right) \quad\left(\mathrm{m}^{3} / \mathrm{mês}-\right.$ médio $)$ 292 38 $166 \quad 22,75$

158 23

166

122

6,5

5,25

151,18

14,75

85

241

20

30

82,7

24,5

54

10,25

123,5

170,7

13,5

178,08

13

22,75

17,67

80

162,5

37,25

135

343

187

35,25

69,75

244

16,33

126,2

20,5

156

93,45

210

183

238,5

100

167

166

137,8

136

154

65

96

165

125

140

160

103
23

29,75

11,5

18

20,5

49

19,5

16

17

14,5

40

25

12,5

15

15

29

28,5

26,5

16,5 
Seqüência Consumo de energia (residência) elétrica

$$
\text { (Kwh/mês - médio) }
$$

39

40

41

42

43

44

45

46

47

48

49

50

51

52

53

54

55

56

57

58

59

60

61

62

63

64

65

66

67

68

69

70

71

72

73

74

75

76

77

78

79

80

81

$$
71,25
$$

215

273

254

180

95,75

213,25

222

230

164,75

183,25

630

157,75

198,5

235,75

185

214,5

237

136

64

75,75

75

68

80,5

332,5

49,25

407,75

136

50

296,25

248,75

200,25

132,5

144,25

128,5

569,75

167

208,5

96,5

91

182

132

166
Resíduos sólidos Área construída Consumo de água gerados

(kg/mês - média) 22,5

52,5

45

180

82,5

11,25

52,5

52,5

45

93,75

75

120

45

78,75

82,5

78,75

71,25

56,25

15

67,5

18,75

41,25

37,5

67,5

30

33,75

165

18,75

71,25

15

45

82,5

22,5

56,25

63,75

45

90

52,5

45

33,75

48,75

45

67,5 do imóvel do imóvel $\left(\mathrm{m}^{2}\right) \quad\left(\mathrm{m}^{3} / \mathrm{mês}-\right.$ médio $)$

$86 \quad 17,5$

158

91

76,25

245

101

140

183

137

198

158,4

568

148

137

221,4

119

80

160

106

128

160

53,5

113

139

117

100

158

100

182

157

268

220

224

257,7

145

139,67

149

134

146

113

134

196

140
60,5

16,5

17,5

20

33

20

12

48

35

24

24

43,5

31

10,5

40,5

25,5

13

53,5

5

28

15,5

4

40

23

28,5

22,5

33

22

27

12

55

33

13,5

13,5

20

53

12

6,5

6

19,5

13

15 
Seqüência Consumo de energia (residência)

$$
\text { (Kwh/mês - médio) (kg/mês - média) }
$$

82

83

84

85

86

87

88

89

90

91

92

93

94

95

96

97

98

99

100

101

102

103

104

105

106

107

108

109

110

111

112

113

114

115

116

117

118

119

120

121

122

123

124

125
298,75

126,5

234,5

82,25

103,5

154,75

148,25

73,75

151,75

196,25

309,75

296

80,75

199,5

153

212,5

160,5

62,25

112,75

148,5

152,5

137,5

73,25

105,25

97

108,75

220,25

116,25

75,75

88,5

106

172,25

94,25

117,5

170,25

80,25

87,5

106,25

192,5

197,5

147,75

103

103

85,5
Resíduos sólidos gerados

22,5

60

78,75

63,75

26,25

48,75

60

71,25

48,75

41,25

135

157,5

48,75

30

108,75

56,25

67,5

30

75

52,5

22,5

37,5

52,5

22,5

52,5

52,5

75

37,5

45

37,5

45

52,5

150

67,5

45

52,5

37,5

67,5

52,5

97,5

67,5

37,5

37,5

45
Área construída Consumo de água do imóvel do imóvel $\left(\mathrm{m}^{2}\right) \quad\left(\mathrm{m}^{3} / \mathrm{mês}-\right.$ médio $)$ 100

80

23,5

128,55

18

101

130

27,5

164,5

150

83

79

150

154

222

117

83

150

142

153

143

155

85

64

61

51

89,35

141,92

95

88

34,75

67

108

79,39

54

68

62

121

94

88,5

60

63

102

247

167,94

167,94

80
10

35

15

11,5

26

4,5

27

33

24

23

23,5

27,5

27

15,25

31,25

11,25

20

14,25

10,5

16

9,25

14,5

18

16

10

25

12,25

21

23,75

10,75

9

20,5

18,75

9

12,5

5

22

14,75

14,75

12 
Seqüência Consumo de energia Resíduos sólidos Área construída Consumo de água (residência) elétrica gerados

$$
\text { (Kwh/mês - médio) ( } \quad \text { kg/mês - média) }
$$

126

127

128

129

130

131

132

133

134

135

136

137

138

139

140

141

142

143

144

145

146

147

148

149

150

151

152

153

154

155

156

157

158

159

160

161

162

163

164

165

166

167

168

169

$$
136,25
$$

174,5

86

75

79,75

204

58,5

59

78

92,75

325,25

124,25

144,5

127,75

112,75

185,25

154,5

127,75

306,25

183

163,5

107,25

208,5

207

188,25

63

169

186,75

94

102,5

147,75

50

161

120,5

124

119,75

132,75

114

157,5

202

84,5

69,25

76,5

312,5
75

82,5

30

37,5

37,5

135

22,5

30

67,5

75

52,5

67,5

67,5

52,5

60

30

82,5

105

60

15

45

52,5

33,75

67,5

112,5

52,5

97,5

90

60

52,5

78,75

41,25

116,25

30

67,5

48,75

101,25

56,25

52,5

108,75

45

52,5

18,75

131,25 do imóvel $\left(\mathrm{m}^{2}\right)$ do imóvel ( $\mathrm{m}^{3} / \mathrm{mês}$ - médio)

$\begin{array}{rr}30 & 10 \\ 120 & 20\end{array}$

$90,75 \quad 23,75$

$60 \quad 22$

$31 \quad 17,5$

$133 \quad 21,5$

$88 \quad 20,3$

$124 \quad 12$

$90 \quad 11$

$187 \quad 18$

$104 \quad 20,5$

$68 \quad 12$

$68 \quad 7$

$92 \quad 22,5$

$196 \quad 4$

$86 \quad 24$

$93 \quad 20$

$135 \quad 19$

$53 \quad 24,25$

$80 \quad 20$

$140 \quad 23$

$155 \quad 13,5$

$198 \quad 12,5$

$133 \quad 52$

$111 \quad 24,5$

$77 \quad 15,25$

$134 \quad 35,5$

$69 \quad 21$

$73,5 \quad 23$

$30 \quad 23$

$105 \quad 20$

$80 \quad 8,75$

$46 \quad 16$

$72 \quad 20$

$44 \quad 22,75$

$65 \quad 24,75$

$47,3 \quad 17,5$

$125,25 \quad 22$

$71 \quad 15$

$95 \quad 23$

$53 \quad 11,5$

$196,8 \quad 8,75$

$108 \quad 11,5$

135

(10)

.

8

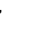

4

(n)

9

0

3

5

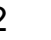

5

1

3

0

6

20




\begin{tabular}{|c|c|c|c|c|}
\hline $\begin{array}{l}\text { Seqüuência } \\
\text { (residência) }\end{array}$ & $\begin{array}{c}\text { Consumo de energia } \\
\text { elétrica } \\
\text { (Kwh/mês - médio })\end{array}$ & $\begin{array}{l}\text { Resíduos sólidos } \\
\text { gerados } \\
\text { (kg/mês - média) }\end{array}$ & $\begin{array}{l}\text { Área construída } \\
\text { do imóvel } \\
\qquad\left(\mathrm{m}^{2}\right)\end{array}$ & $\begin{array}{l}\text { Consumo de água } \\
\text { do imóvel } \\
\text { (m³/mês - médio) }\end{array}$ \\
\hline 170 & 194,75 & 75 & 92 & 5,5 \\
\hline 171 & 251,25 & 86,25 & 80 & 32,75 \\
\hline 172 & 120,25 & 41,25 & 100 & 25 \\
\hline 173 & 143,5 & 135 & 112 & 10 \\
\hline 174 & 61,25 & 75 & 63 & 6,5 \\
\hline 175 & 193,75 & 52,5 & 83 & 20,3 \\
\hline 176 & 113,5 & 37,5 & 80 & 15,5 \\
\hline 177 & 85 & 45 & 53,12 & 16,25 \\
\hline 178 & 186 & 48,75 & 34,75 & 22 \\
\hline 179 & 242 & 90 & 59,09 & 36,5 \\
\hline 180 & 125,5 & 26,25 & 84 & 11,67 \\
\hline 181 & 121,5 & 56,25 & 85 & 21 \\
\hline 182 & 137 & 90 & 47 & 24 \\
\hline 183 & 87,25 & 97,5 & 34,75 & 25 \\
\hline 184 & 117,75 & 78,75 & 87 & 25 \\
\hline 185 & 51,75 & 11,25 & 73 & 4,5 \\
\hline 186 & 44 & 52,5 & 75,6 & 7,5 \\
\hline 187 & 152,75 & 97,5 & 117,88 & 15 \\
\hline 188 & 140,75 & 120 & 57,33 & 20 \\
\hline 189 & 86,75 & 75 & 93 & 20 \\
\hline 190 & 127 & 97,5 & 80 & 23,25 \\
\hline 191 & 71,5 & 7,5 & 78,66 & 1,5 \\
\hline 192 & 54,75 & 33,75 & 80 & 10 \\
\hline 193 & 122 & 37,5 & 88,72 & 14 \\
\hline 194 & 153,75 & 142,5 & 89 & 18,5 \\
\hline 195 & 61 & 30 & 60 & 6,25 \\
\hline 196 & 61,75 & 63,75 & 64,64 & 18,25 \\
\hline 197 & 143,5 & 135 & 112 & 10 \\
\hline 198 & 61,25 & 75 & 63 & 6,5 \\
\hline 199 & 251,25 & 86,25 & 80 & 32,75 \\
\hline 200 & 113,5 & 37,5 & 80 & 15,5 \\
\hline
\end{tabular}

